\title{
Applicability of Slug Interference Tests Under Hanford Site Test Conditions: Analytical Assessment and Field Test Evaluation
}

\section{F. A. Spane, Jr.}

April 1992

Prepared for the U.S. Department of Energy under Contract DE-AC06-76RLO 1830

Pacific Northwest Laboratory

Operated for the U.S. Department of Energy by Battelle Memorial Institute 


\title{
DISCLAIMER
}

This report was prepared as an account of work sponsored by an agency of the United States Government. Neither the United States Government nor any agency thereof, nor Battelle Memorial Institute, nor any of their employees, makes any warranty, expressed or implied, or assumes any legal liability or responsibility for the accuracy, completeness, or usefulness of any information, apparatus, product, or process disclosed, or represents that its use would not infringe privately owned rights. Reference herein to any specific commercial product, process, or service by trade name, trademark, manufacturer, or otherwise does not necessarily constitute or imply its endorsement, recommendation, or favoring by the United States Government or any agency thereof, or Battelle Memorial Institute. The views and opinions of authors expressed herein do not necessarily state or reflect those of the United States Government or any agency thereof.

\author{
PACIFIC NORTHWEST LABORATORY \\ operated by \\ BATTELLE MEMORIAL INSTITUTE \\ for the \\ UNITED STATES DEPARTMENT OF ENERGY \\ under Contract DE-ACO6-76RLO 1830
}

Printed in the United States of America

Available to DOE and DOE contractors from the

Office of Scientific and Technical Information, P.O. Box 62, Oak Ridge, I.V 37831; prices available from (615) 576-8401. FTS 626-8401.

Available to the public from the National Technical Information Service, U.S. Department of Commerce, 5285 Port Royal Rd., Springfield, VA 22161. 
PRL- -8070

DE92 013065

APPLICABILITY OF SLUG INTERFERENCE TESTS

UNDER HANFORD SITE TEST CONDITIONS:

ANALYTICAL ASSESSMENT AND FIELD TEST

EVALUATION

F. A. Spane, Jr.

Apri1 1992

Prepared for

the U.S. Department of Energy

under Contract DE-AC06-76RLO 1830

Pacific Northwest Laboratory

Richland, Washington 99352 


\section{ABSTRACT}

Slug interference testing may be a useful technique for characterizing the hydraulic properties of high conductivity formations where problems associated with disposal of contaminated ground water make pumping tests undesirable. The suitability of the siug interference method for characterizing the unconfined aquifer at the Hanford Site was evaluated in a twophase investigation.

The first phase consisted of an analytical assessment. Siug interference responses were predicted over the range of conditions expected for the aquifer. Results of the analytical assessment showed that the test can be used for charactarizing formations with hydraulic conductivities up to $10^{4} \mathrm{ft} / \mathrm{d}$ if the observation well is located within $100 \mathrm{ft}$ of the stress well. This is a higher conductivity range than is possible with single well slug tests. The effects of partial penetration, delayed-yield and aquifer anisotropy on expected test results were also evaluated and possible analytical corrections are presented.

The field test evaluation was conducted at a site with two observation wells and a stress well. Results verified the analytical evaluation and gave reasonable values of hydraulic conductivity and storativity. Test design considerations that optimize the observed response are discussed. 


\section{SUMMARY}

A two-phase investigation was performed to evaluate the applicability of slug interference testing to hydraulically characterize the unconfined aquifer under Hanford Site conditions. The two-phase study included an initial analytical assessment to examine predicted areal slug interference responses over a wide-range of Hanford Site conditions. This was followed by a field test evaluation of the proposed test technique.

Initial results of the analytical assessment and field evaluation for utilizing the test method to support hydraulic characterization investigations on the Hanford Site are encouraging. It would appear to be particularly attractive for providing hydraulic characterization in contaminated areas where the use of standard hydrologic characterization methods (e.g., pumping tests) may not be possible (i.e., due to disposal problems created by the production of contaminated ground water). The evaluation indicates that the slug interference test method can be utilized to provide hydraulic characterization of the unconfined aquifer on the Hanford Site over a range of test conditions that exceeds those of single-well slig tests. High hydraulic conductivity sections (i.e., up to $10^{4} \mathrm{ft} / \mathrm{d}$ ) of the unconfined aquifer can be successfully characterized using this test method if the point of observation of the slug interference (i.e., the observation well location) is located within $100 \mathrm{ft}$ of the point of stress (i.e., the stress well location).

Salient firdings of the analytical assessment of slug interference testing with respect to aquifer/test conditions and ranges of hydrogeologic properties representative of the unconfined aquifer at the Hanford Site are outlined below:

\section{Aquifer/Test Conditions}

1. Slug interference tests are expected to provide valid characterization information for test intervals that exhibit: confined and semi-confined conditions, and for unconfined aquifers that display test responses that are reflective of time-drawdown behavior that is not significantly influenced by delayed-yield (i.e., vertical flow/leakage) effects. 
2. Slug interference tests would not be expected to provide valid hydraulic characterization results for small test intervals at the water-table surface. This is due to conditions imposed by the presence of a free-surface boundary, and the damping effect imposed by the water table.

3. To be successfully analyzed with the existing analytical methods (i.e., the computer program presented in Novakowski, 1990), the slug peak or central slug interference "hump" should not be significantly affected by delayed-yield test behavior.

4. The presence of delayed-yield behavior can be discerned by converting the observed slug test data to an equivalent head response that would be predicted for a constant-rate pumping test. Conversion of slug test response data to equivalent head values associated with constant-rate tests can be accomplished following the transformation procedure described in Peres, et al. (1989). The presence of delayed-yield behavior can then be assessed using pressure derivative analysis of the equivalent head response.

5. The effects of partial penetration cause distortion of the radial flow/equipotential pattern that would normally develop during testing within a homogeneous, isotropic aquifer surrounding a fully penetrating stress well. Partial penetration effects cause additional drawdown to occur within the surrounding screened depth interval section of the aquifer, and less drawdown to occur within the non-screened aquifer section.

6. Deviations induced by partial penetration are more significant near the stress well and diminish with distance. Flow patterns during testing are essentially radial for observation well distances $\geq 1.5$ times the aquifer thickness; and for practical purposes equations based on fully penetrating stress wells (e.g., Theis equation) provide sufficiently accurate results for observation well distances as small as the aquifer thickness (i.e., $r / b \geq 1$ ).

7. The effects of vertical anisotropy tend to amplify the drawdown deviations caused by partial penetration. Because of the presence of stratification that is evident to some degree in most sediments, vertical anisotropy would be expected to influence test results obtained within sedimentary aquifers.

8. For a given distance, $r$, from a partially penetrating stress well, the effects of anisotropy would be the same as that at the distance $r\left(K_{z} / K_{h}\right)^{1 / 2}$ within an equivalent isotropic aquifer; where $K_{z}=$ vertical hydraulic conductivity, and $K_{h}=$ horizontal hydraulic conductivity. The effects of vertical anisotropy, then, can be accounted for using this relationship, if the ratio of vertical to horizontal conductivity is known or can be estimated for the test formation. 
9. To be successfully analyzed with the existing analytical methods (i.e., the computer program presented in Novakowski, 1990), the siug peak or central slug interference "hump" should not be significantly affected by the effects of partial penetration and vertical anisotropy.

10. For observation well distances within a radial distance less than an aquifer thickness away from the stress well (i.e., $r / b<1$ ), effects for partial penetration can be accounted for following procedures out 1 ined in Weeks (1969). The effects of vertical anisotropy can also be accounted for (if known) given the relationship presented in Hantush (1961).

\section{Hydrogeologic Property Effects}

1. Slug interference tests can be successfully conducted for test intervals with transmissivities ranging up to $10^{5} \mathrm{ft}^{2} / \mathrm{d}$. This represents a significant extension of single-well slug test capabilities, which are limited to transmissivities of less than approximately $10^{3} \mathrm{ft}^{2} / \mathrm{d}$,

2. High transmissivity test formations are associated with fast slug interference test responses monitored at adjacent observation wells, while lower test interval transmissivities are associated with lagged interference responses.

3. Test formation storativity is the principal hydrogeologic parameter controlling the amplitude of the slug interference response monitored at adjacent points of obsarvation. Because of this dependence, slug interference tests are far superior to single-well slug tests for estimating test formation storativity.

4. Slug interference responses diminish rapidly with distance from the stress well location. However, for the hydrogeologic conditions considered representative for the Hanford Site, discernable slug interference responses should be observable to distances up to $100 \mathrm{ft}$ from the stress well.

5. Wellbore storage at the stress well exerts a significant influence on the amplitude of the slug interference response that propogates through the surrounding test formation. Larger wellbore storage conditions (i.e., greater well casing diameters) cause larger areal slug interference responses. Conversely, larger observation well wellbore storage conditions cause slug interference responses to be lagged and attenuated from predicted responses where observation wellbore storage is negligible.

To maximize slug interference test responses, therefore, efforts should be made to increase wellbore storage conditions at the stress well and to reduce wellbore storage at observation wells (e.g., through use of downhole packers, etc.). 
Results of the field test evaluation were also encouraging and indicate that analyzable slug interference responses were obtained at two nearby observation wells. The monitoring zones of the two observation wells are located approximately 48 and $49 \mathrm{ft}$, respectively, from the stress well test interval. Slug interference-derived transmissivity estimates obtained for the unconfined aquifer between the stress well and observation wells provided estimates ranging between 145 to $310 \mathrm{ft}^{2} / \mathrm{d}$; which, based on an aquifer thickness of $52 \mathrm{ft}$, provides an estimate range of equivalent hydraulic conductivity between $2.8 \mathrm{ft} / \mathrm{d}$ and $6.0 \mathrm{ft} / \mathrm{d}$ for the aquifer between the stress and observation well locations. This hydraulic conductivity range compares favorably with single-well slug test analysis results obtained at the stress well (i.e., equivalent hydraulic conductivity ranging between $2.3 \mathrm{ft} / \mathrm{d}$ and $5.7 \mathrm{ft} / \mathrm{d}$ ) during interference testing, which was representative of the screened interval test section. Less correspondence is exhibited, however, with previously conducted low-stress, single-well slug tests estimates that were obtained at the observation we 11 locations (i.e., between $0.4 \mathrm{ft} / \mathrm{d}$ and $1.0 \mathrm{ft} / \mathrm{d}$, and between $1.4 \mathrm{ft} / \mathrm{d}$ and $2.8 \mathrm{ft} / \mathrm{d}$ for we $11 \mathrm{~s}$ 699-43-41E and $-43-41 \mathrm{~F}$, respectively). The reason for the lower correspondence in property estimates for the previously conducted single-well slug test is not known; however, it may be related to the significantly smaller range of investigation attributed to the low stress level (approximately $1 / 10$ that utilized during the slug interference test), which was imposed at the observation welis during the previous tests.

Storativity estimates obtained from slug interference test analysis for the observation wells provided similar results ranging between $2.9 \times 10^{-3}$ and $4.4 \times 10^{-3}$. These estimated storativity values suggest semi-confined conditions, but are also within the elastic response range commonly exhibited by unconfined aquifers (e.g., Gambolati 1976; Neuman 1974, 1979). 


\section{ACKNOWLEDGMENTS}

A number of people collaborated in the conduct of the field slug interference test. In particular, important contributions were made by P. D. Thorne of Pacific Northwest Laboratory (PNL) and R. L. Jones of Westinghouse Hanford Company (WHC). Numerous individuals also provided technical peer review comments of the test analysis results including: C. D. Delaney, R. L. Jackson, and A. G. Law all of WHC, and P. D. Thorne of PNL. The editorial review and guidance provided by $W$. R. Gorst of PNL are al so acknowledged. 


\section{CONTENTS}

ABSTRACT

SUMMARY

1.0 INTRODUCTION

1.1

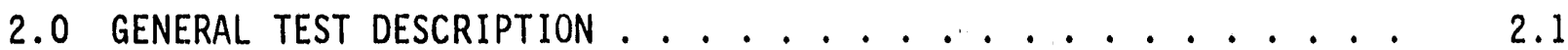

3.0 ANALYTICAL ASSESSMENT . . . . . . . . . . . . . . 3.1

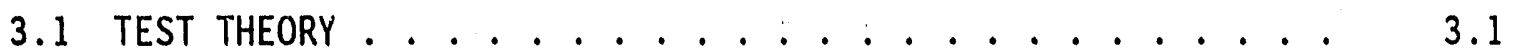

3.2 APPLICABILITY OF TEST METHOD UNDER HANFORD SITE CONDITIONS . . . . . . . . . . . . . . . . 3.2

3.2.1 Hanford Site Unconfined Aquifer . . . . . . . . . 3.4

3.2.2 Partial Penetration and Vertical Anisotropy . . . 3.8

3.2.3 Transmissivity . . . . . . . . . . . . 3.11

3.2.4 Storativity ............... . 3.13

3.2.5 Radial Distance ............... 3.14

3.2.6 Observation Wellbore Storage . . . . . . . . 3.16

3.3 TEST METHOD CONSIDERATIONS . . . . . . . . . . . . 3.18

3.3.1 Test Design . . . . . . . . . . . . . . 3.18

3.3.2 Test Method Initiation/Test Equipment . . . . . 3.21

4.0 FIELD TEST EVALUATION - TEST EXAMPLE . . . . . . . . . . 4.1

4.1 TEST SITE DESCRIPTION . . . . . . . . . . . . 4.1

4.2 TEST EQUIPMENT ..................... 4.1

4.3 TEST DESCRIPTION . . . . . . . . . . . . . . . . 4.7

4.4 TEST ANALYSIS . . . . . . . . . . . . . . 4.10

4.4.1 Barometric Effects ............. 4.10

4.4.2 Stress Well 699-43-41G Response . . . . . . . 4.14 
4.4.3 Observation Well 699-43-41E Response....... 4.22

4.4.4 Observation Well 699-43-41F Response....... 4.26

5.0 CONCLUSIONS . . . . . . . . . . . . . . . . . . 5.1

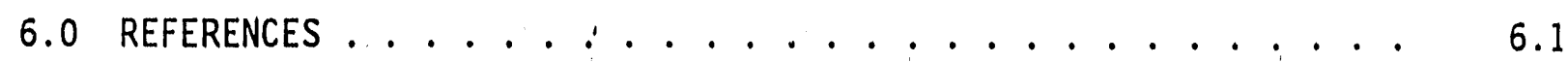

APPENDIX A - COMPARISON OF NOVAKOWSKI PROGRAM-GENERATED SLUG TEST RESPONSES, WITH PUBLISHED TYPE CURVE RESPONSES AT THE STRESS WELL AND OBSERVATION WELL ........... A.1

APPENDIX B - SLUG INTERFERENCE TEST DATA . . . . . . . . . . . B. 1

APPENDIX C - PREVIOUS SINGLE-WELL SLUG TEST ANALYSIS RESULTS . . . . C. 


\section{FIGURES}

2.1 Well Completion, Geometric Relationships, and Test Equipment

Details for Two, Dual-We11 Test System Configurations .. . . . .

3.1 Characteristic Time-Drawdown Behavior for Unconfined Aquifer Conditions, During a Constant-Rate Pumping Test . . . . . . .

3.2 Affects of a Partially Penetrating Pumping Well Completed in the Lower 30 Percent of a Confined Aquifer ... . . . . . . . .

3.3 Predicted Slug Test Response at the Stress Well for a Transmissivity Range $10^{3}$ to $10^{5} \mathrm{ft}^{2} / \mathrm{d}$, and a Storativity of $10^{-3}$

3.4 Predicted Slug Interference Response at a Radial Distance of $10 \mathrm{ft}$ from the Stress Well, for a Transmissivity Range $10^{3}$ to $10^{5} \mathrm{ft}^{2} / \mathrm{d}$ and a Storativity of $10^{-3} . . . . . . . . . .$.

3.5 Predicted Slug Test Response at the Stress Well for a Storativity Range $10^{-1}$ to $10^{-4}$, and a Transmissivity of $10^{3} \mathrm{ft}^{2} / \mathrm{d}$

3.6 Predicted Slug Interference Response at a Radial Distance of $10 \mathrm{ft}$ from the Stress Well, for a Storativity Range $10^{-1}$ to

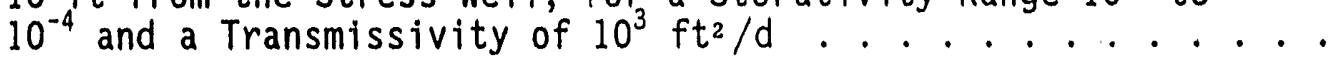

3.7 Predicted Maximum Slug Interference Response as a Function of Radial Distance from the Stress Well Location, for Storativity Values, $S, 10^{-1}$ to $10^{-4} \ldots . . \ldots$

3.8 Comparison of Predicted Slug Interference Response for a Family of $C_{D s}$ Type Curves, for the Case Where $C_{D_{0}} \ll C_{D s}$

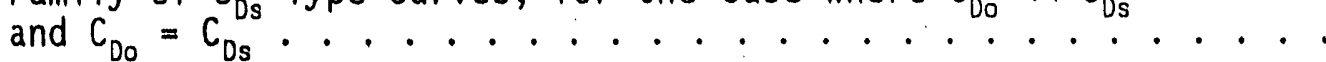

$3.9 H_{D}$ Versus $R_{D}$ Type Curves for $C_{D}$ Values: $1.25,12.5,125$, and 1250

$3.10 R_{D}$ Versus $T_{D} / C_{D}$ Type Curves for $C_{D}$ Values: $1.25,12.5,125$, and 1250

3.11 a) $H_{D}$ Versus $T_{D} / C_{D}$ Type Curves for $R_{D}=30 \ldots . . . . . . .22$

b) $H_{D}$ Versus $T_{D} / C_{D}$ Type Curves for $R_{D}=75 \ldots . . . . .22$

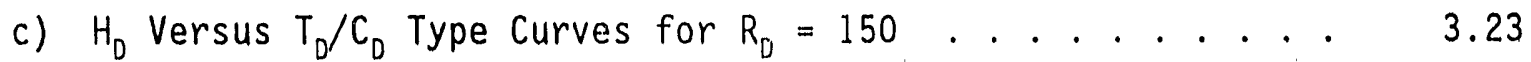

d) $H_{D}$ Versus $T_{D} / C_{D}$ Type Curves for $R_{D}=300$. . . . . . . 3.23

4.1 Location Map of Slug Interference Test Facility . . . . . . . 4.2 
4.2 Construction As-Builts and Test Equipment Installations for Observation Wells 699-43-41E and 699-43-41F ........ 4.4

4.3 Temporary We11 Completion and Test Equipment Installation Information for Well 699-43-41G . . . . . . . . . . . . 4.5

4.4 General Wellhead Assembly Components for Well 699-43-41G . . . . 4.8

4.5 Comparison of Dolwnhole Pressure Measurements for Weils 699. 43-41E and 699-43-41F and Atmospheric Pressure Readings Observed During the Period August 26 to 30,1991 . . . . . . 4.11

4.6 Barometric Efficiency Calculation for Observation Wells 69943-41E and 699-43-41F ................... 4.14

4.7 Slug Test Bnalysis for Stress Well 699-43-41G Using the Ostrowski and Kloska Analysis Method . . . . . . . . .. 4.15

4.8 Dimensionsless Pressure and Dimensionsless Pressure Derivative Type Curves for Constant-Rate Pumping Tests . . . . . . . . .

4.9 Diagnostic Analysis of Equivalent Head and Equivalent Head Derivative Plot Data for Slug Test Conducted at Well 699-43-41G....................... 4.18

4.10 Slug Test Analys is for Stress We11 699-43-41G Using the Bouwer and Rice Analysis Method ..............

4.11 Slug Interference Response Data Recorded at Observation

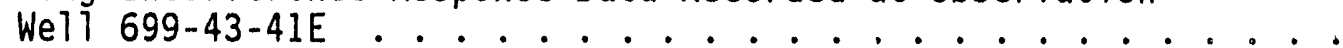

4.12 Slug Interference Test Aialysis for Well 699-43-41E Showing: a) Effect of Varying Storativity, and b) Effect of Virying Transmissivity.....................

4.13 Diagnostic Analysis of Equivalent Head and Equivalent Head Derivative Plot Data for Slug Interference Test observed at Well 699-43-41E

4.14 Slug Interference Response Data Recorded at Observation Wel1 699-43-41F ....................

4.15 Slug Interference Test Analys is for We11 699-43-41F Showing . .

4.16 Diagnostic Analysis of Equivalent Head and Equivalent Head Derivative Plot Data for Slug Interference Test Observed at Well 699-43-41F 


\section{TABLES}

3.1 Parameter Ranges Used for Assessing the Applicability of Slug Interference Tests Under Hanford Site Conditions . . . . . 3.3

4.1 Pertinent Well Completion and Construction Information for We11s 699-43-41E, 699-43-41F, and 699-43-41G . . . . . . . . 4.3

4.2 Calculated Distance Relationships Between Wells 699-43-41E, 699-43-41F, and 699-43-41G ............... 4.3 


\subsection{INTRODUCTION}

Pacific Northwest Laboratory (PNL), in cooperition with Westinghouse Hanford Company, provided hydrologic testing support for a hydraulic characterization investigation that was conducted in the vicinity of the B-Pond facility. Specific PNL work tasks included the design, conduct, and evaluation of a developmental slug interference test method that was conducted as part of hydraulic characterization activities for the newly constructed we11 699-43-41G test facility. Results of the field test eval:1ation were utilized by PNL in its assessment of the applicability of slug interference testing under Hanford Site conditions.

Current RCRA and CERCLA hydrologic characterization studies on the Hanford Site have, in some cases, been restricted by existing site conditions, e.g., contaminated ground water, purge-water disposal problems, high formation permeabilities, etc. The presence of contaminated ground water and, in some locations, areas of extremely high transmissivity (e.g., 200 East Area) greatly diminishes the ability of standard hydraulic tost methods to hydrologically characterize subsurface materials. A need clearly exists to develop new test methods and/or to modify currently used techniques, to improve ongoing and future hydraulic characterization investigations on the Hanford Site. Of particular interest are test methods that can be performed rapidly, and that minimize the removal of large quantities of water (i.e., tests that minimize purge-water disposal problems).

One test method that appears to hold particular promise is slug interference testing. This test technique requires a two-well installation: a stress we11 and an observation we11. The general test procedure requires an instantaneous head increase or decrease be initiated at the stress well, and the associated formation response be monitored at the neighboring observation we11. Analysis of the monitored pressure response at the observation well provides estimates of the formation transmissivity and storativity. It should be noted that because of the high transmissivity of the unconfined aquifer over much of the Hanford Site, estimates of hydraulic properties commonly can not be obtained solely from stress well (i.e., single well) slug test results. 
Slug interference testing has been utilized infrequently in the past, with its use primarily limited to hydraulically characterizing confined formations having low storativities, i.e., between $10^{-4}$ and $10^{-6}$ (e.g., Novakowski, 1989). The objective of this study is to evaluate the applicability of slug interference testing for hydraulically characterizing formations under unconfined or semi-confined conditions (i.e., between $10^{-4}$ and $10^{-1}$ ). The study consists of two major elements: an analytical assessment that evaluates the sensitivity of slug interference responses to a range of hydrogeologic and site geometric conditions, which are representative of the unconfined aquifer on the Hanford Site; and a field test evaluation at a selected site that examines aspects of performing a slug interference test and compares analysis results obtained with previously conducted hydraulic characterization tests.

The analytical assessment element includes the generation of computerderived, theoretical resnonses to slug interference tests for a wide-range of hydrogeologic conditions for which this technique may be viable for hydraulic characterization investigations at the Hanford Site. The parameters evaluated include transmissivity, storativitj', distance between siress and observation wells, and magnitude of slug stress levels. Results of the computer analysis are included in the report, as well as

- a set of type curve graphs that demonstrate the range of applicability for the test method under Hanford Site conditions,

- a set of type curve graphs that can be used for the design of slug interference tests, and

- a list of recommendations that relate to test method and equipment considerations for performing slug interference tests.

The field test evaluaiion element of the study consists of assessing the performance of conducting a slug interference test at a previously characterized, multiple-well facility on the Hanford Site. Principal components of this study element include assessing aspects of conducting field slug interference tests, developing procedures for test data reduction and analysis, and the comparison of slug interference analys is results with previously conducted hydraulic characterization tests. 


\subsection{GENERAL TEST DESCRIPTION}

Most simply described, the slug interference test technique requires a two-well installation: a stress well and an observation we11. The general test procedure requires a head increase or decrease be initiated at the stress we 11 , and the associated formation response (i.e., the slug interference) be monitored at the neighboring observation we11. Analysis of the monitored pressure response at the observation well provides estimates of formation transmissivity and storativity.

Figure 2.1 shows well completion, geometric relationships, and test equipment installations for two different dual-well test system configurations that may be used for conducting slug interference tests at the Hanford Site. The test system configurations shown include locations where the water table is above (Figure 2.1a) or within (Figure 2.1b) the screened interval. 


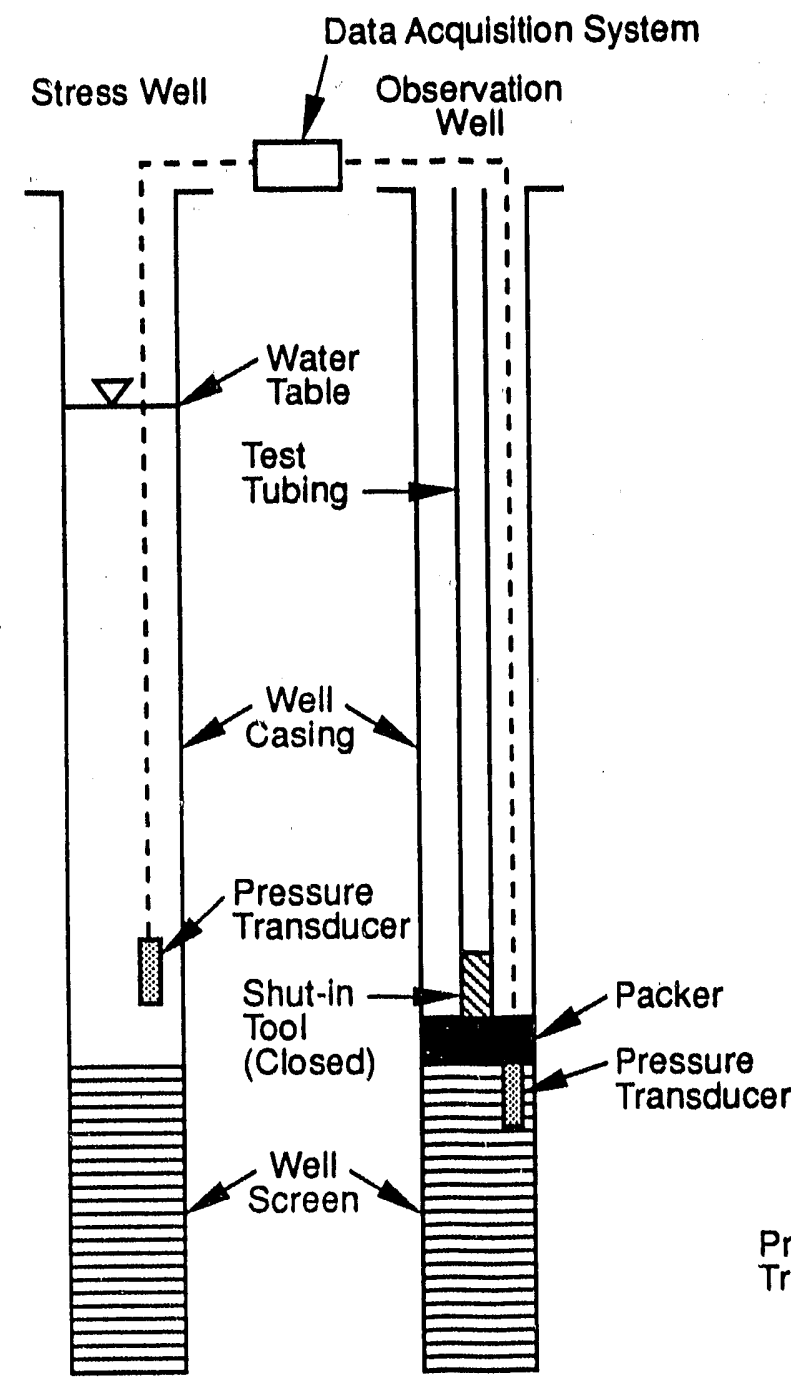

a

Water Table Above Well Screen

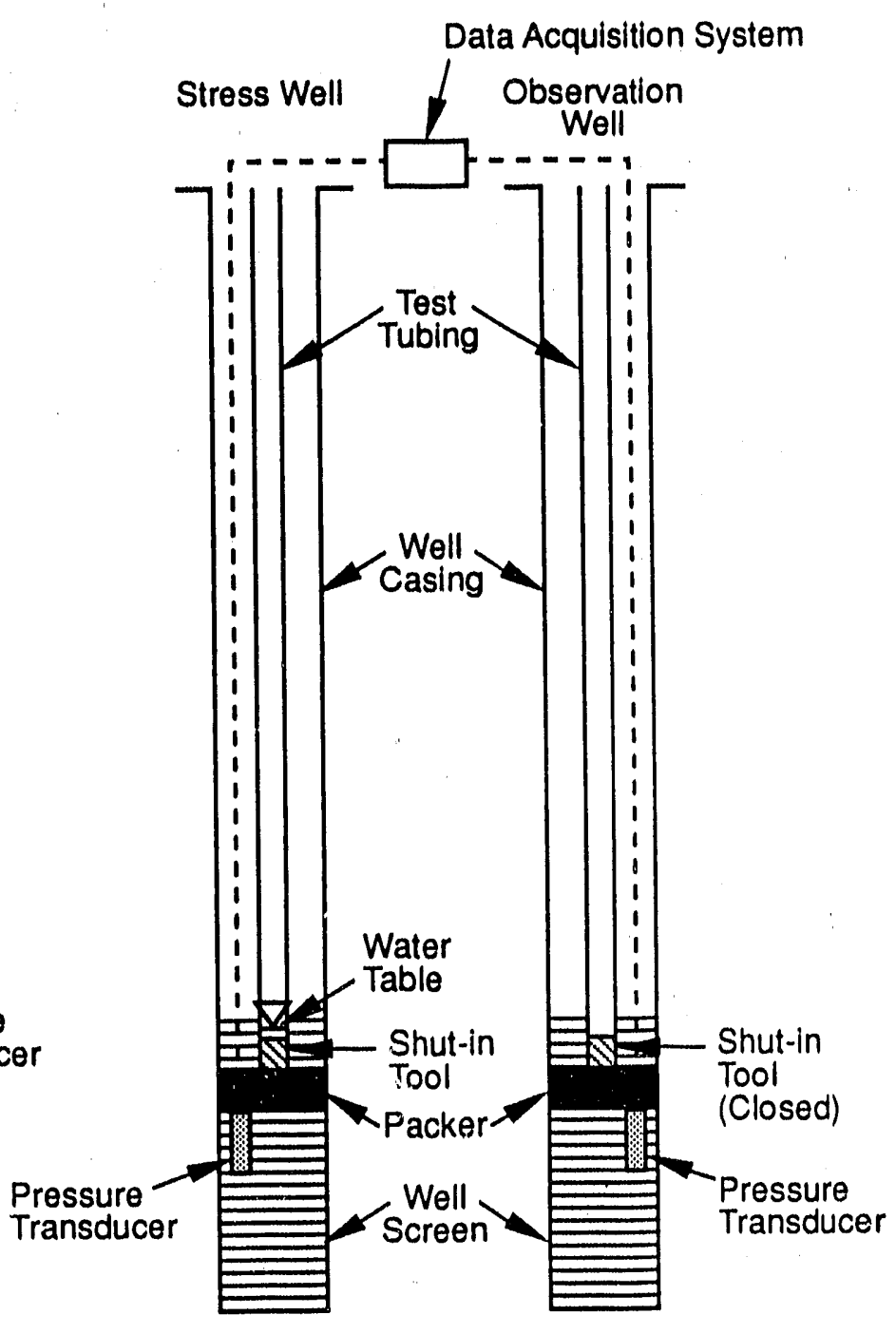

b

Water Table Within

Well Screen

$\$ 9202087.3$

FIGURE 2.1. Well Completion, Geometric Relationships, and Test Equipment Details for Two, Dual-Well Test System Configurations

a) Water Table Above Well Screen b) Water Table Within Well Screen 


\subsection{ANALYTICAL ASSESSMENT}

\subsection{TEST THEORY}

The analytical solution for a slug test response for a stress well with a finite radius within an aquifer containing a semi-compressibie fluid, was first presented in Cooper et a1. (1967). In their article, type curves were presented that related dimensionless head response, $H_{D}$, versus the dimensionless time parameter, $\beta$, for various values of the dimensionless storage parameter, $\alpha$, at the stress well location; where:

$$
\begin{aligned}
& H_{0}=H / H_{0} \\
& B=T t / r_{c}{ }^{2} \\
& \alpha=r_{w}^{2} S / r_{c}{ }^{2}
\end{aligned}
$$

where $H=$ observed head at time $t$, minus pre-test static head level in well

$$
\begin{aligned}
H_{0}= & \text { instantaneous head change applied to well } \\
T= & \text { transmissivity of test interval } \\
t= & \text { test time } \\
r_{c}= & \begin{array}{l}
\text { radius of well casing in the interval over which head change takes } \\
\text { place }
\end{array} \\
r_{w}= & \text { effective radius of well within test interval } \\
S= & \text { storativity of test interval }
\end{aligned}
$$

The type curves can be used to match slug test response data at the stress well to solve for transmissivity (T) and storativity (S) using Equations (2) and (3), respectively. The Cooper et al. (1967) analytical solution in theory is strictly valid only for a fully penetrating well in a confined aquifer. Their solution, however, yields acceptable results for partially penetrating wells and unconfined aquifer tests provided that the saturated thickness of the unconfined aquifer does not change significantly (Walter and Thompson 1982) and radial flow conditions exist (i.e., no significant vertical 
flow components). While these conditions may be violated to some degree at the stress well, they should be acceptable at nearby points of observation.

Novakowski (1990) presented a FORTRAN program that can generate slug interference test type curves based on the analytical solutions and boundary conditions presented in Cooper et al. (1967). As stated in Novakowski (1990), the analytical solution: included in the program are given in the Laplace domain and are numerically inverted to generate data for the type curves. A modified version of the program was utilized to assers the applicability of slug interference testing for hydraulic characterization studies on the Hanford Site. The original program was modified to allow increased density of generated type-curve data points, to extend the dimensionless head lower limit, and to provide additional test description information in the computer file output. A detailed description of the original program and its use is contained in Novakowski (1990).

To assess its validity, the modified program version was utilized and compared with slug test type-curve examples presented in Cooper et a1. (1967) for the stress well and Ramey et a1. (1975) for slug interference responses. The test comparisons are presented in Appendix A. As indicated, the modified Novakowski (1990) program produced test results that were in close agreement with the aforementioned published type-curve data (i.e., within 3 or 4 significant decimal places for dimensionless head, $H_{0}$ ).

\subsection{APPLICABILITY OF TEST METHOD UNDER HANFORD SITE CONDITIONS}

To assess the applicability of the slug interference test method under Hanford Site conditions, a set of hydraulic property and geometric relationships were assumed. Table 3.1 lists the assumed parameter ranges used in the assessment. The range for hydraulic conductivity was selected from reported values in Gephart et a1. (1979) and DOE (1988) for the more permeable sections of the unconfined aquifer at the Hanford Site. The range for storativity was obtained from multiple-well pumping test results for various stratigraphic formations of the unconfined aquifer (e.g., Hanford, middle Ringold, basal Ringold, etc.) as reported in DOE (1988). 
TABLE 3.1. Parameter Ranges Used for Assessing the Applicability of Slug Interference Tests Under Hanford Site Conditions

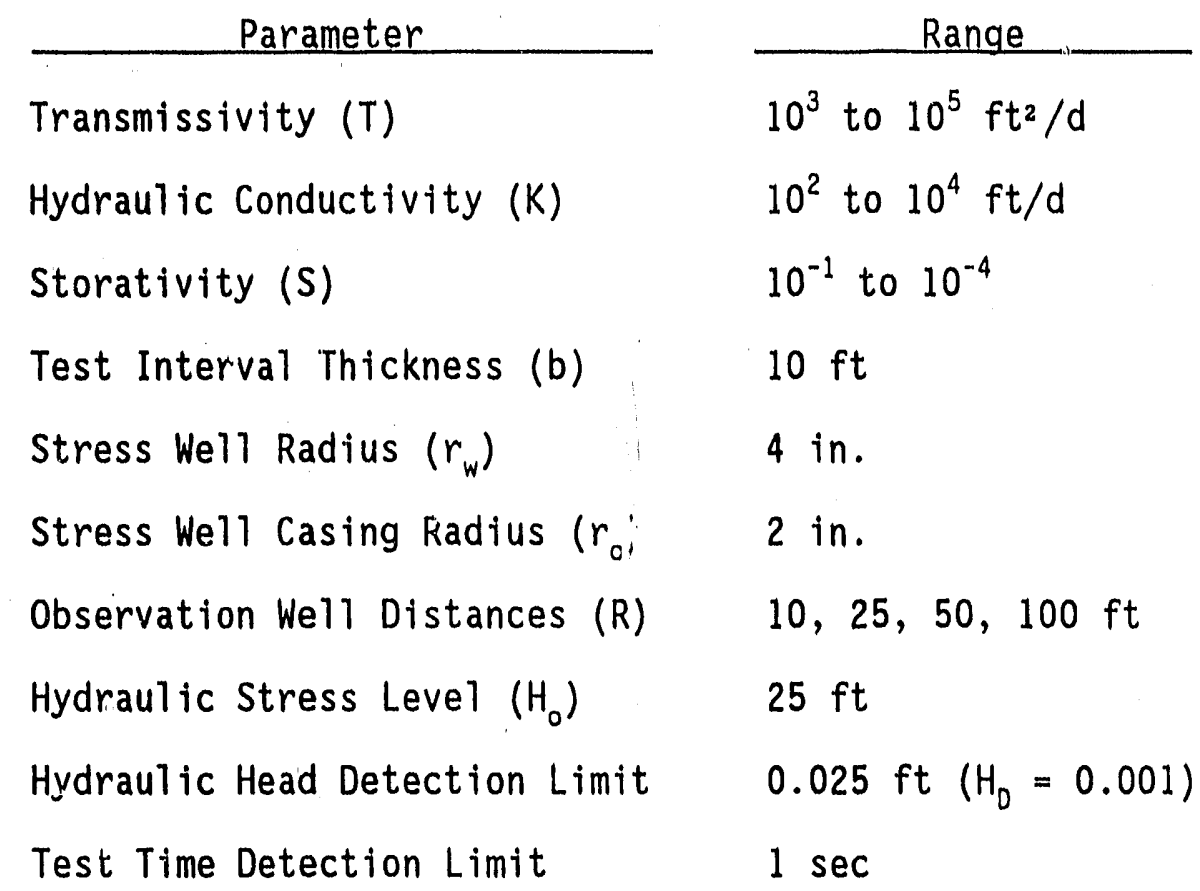

Test interval thickness, well diameter, and we11 casing diameter values were taken from common well completion design specifications of RCRA and CERCLA programs. Observation well distance values were arbitrarily selected, but are considered representative of several cluster monitoring well facilities on the Hanford Site. The hydraulic stress level of $25 \mathrm{ft}$ was selected for the test evaluation as the minimum, practical slug stress level to be used during slug interference testing. For higher stress levels, proportionally higher interference responses would be exhibited. Hydraulic head and test time detection limits were arbitrarily selected, but are consistent with test equipment and data acquisition systems utilized for hydraulic characterization studies on the Hanford Site.

Results of the sensitivity analyses for various specified parameter values, using a modified version of the Novakowski program, are presented in the Subsections 3.2.3 through 3.2.6. 


\subsubsection{Hanford Site Unconfined Aquifer}

The unconfined aquifer on the Hanford Site consists of glactofluvial deposits of the Hanford formation (informal designation) and/or fluvtal and lacustrine deposits of the Ringold Formation. Hydraulic conductivities for the two formations comprising the unconfined aquifer vary considerably across the Site. Units of the overlying Hanford formation usually exhibit higher hydraulic conductivity values, which range between $10^{2}$ and $10^{4} \mathrm{ft} / \mathrm{d}$, while members of the underlying Ringold Formation range between $10^{-1}$ and $10^{3} \mathrm{ft} / \mathrm{d}$ (Gephart et a1. 1979). Over a large part of the Hanford Site, the Hanford formation lies above the water table. However because of its inherently higher permeability, it represents a significant hydrogeologic unit for the transport of contaminated ground water within the unconfined aquifer in those regions where it is saturated (e.g., in the 200 East Area).

As suggested by the wide-range in hydrautic conductivity values, the unconfined aquifer is heterogeneous in nature and generally consists of alternating layers of sands, gravels, silts and clays. The presence of silts and clays within the aquifer (especially within the Ringold Formation) can cause ground-water conditions to be locally semi-confined in nature. For these reasons, storativity values obtained from multiple-well pumping tests for the unconfined aquifer are reported to range between $2 \times 10^{-4}$ to $2 \times 10^{-1}$ (DOE 1988).

The program (Novakowski 1990) used to assess the applicability of slug interference testing in this report (as well as other analytical methods based on the Theis equation, e.g., Cooper et a1. 1967), was developed specifically for confined aquifer conditions. The primary difference in how an unconfined aquifer (i.e., in comparison to a confired aquifer) responds during testing is related to the manner ground water is released from the aquifer to the well, and the fact that the upper flow boundary (i.e., water table) is not fixed as is the case in the confined aquifer situation.

For confined aquifers, ground water is released from elastic storage and by compression of the aquifer matrix, while for unconfined aquifers ground water is produced from both elastic storage and by gravity drainage from the lowering water-table surface (see also Section 3.2.4). As test time increases 
the elastic storage, $S_{e}$, response becomes less important within the unconfined aquifer, with ground-water production being controlled largely by its specific yield, $S_{y}$. The early elastic storage response within an unconfined aquifer during early test times is well documented (e.g., Gambolati 1976; Neuman 1974, 1979).

The fact that unconfined aquifers produce ground water from two sources of storage and that the water table is not fixed during testing, causes unconfined aquifer pumping tests to depart from chat predicted by the Theis equation. Walton (1960) states that unconfined aquifer constant rate pumping tests are characterized by the presence of three distinct segments on a time-drawdown curve. In the first segment, the aquifer reacts as would a confined aquifer, with ground water produced through the expansion of water and compaction of the aquifer matrix. Drawdowns during this segment follow that predicted using the Theis equation, with storativity equal to only its elastic storaye component $\left(S_{e}\right)$. During the second segment of the drawdown curve, the rate of drawdown decreases as gravity drainage (t.e., vertical ground-water flow components) become important within the aquifer. Gravity drainage (also referred to as delayed yield) within the unconfined aquifer causes the time-drawdown curve to deviate significantiy from that predicted by the Theis equation, since the gravity drainage/vertical ground-water flow components "reflect the presence of recharge in the vicinity of the pumped we11". During the third segment gravity drainage effects become insignificant and radial flow conditions are once again predominant within the aquifer.

Drawdowns during this segment once again follow that predicted using the Thets equation, with storativity equal to its combined elastic storage component, $S_{e}$, and specific yield, $S_{y}$.

The influence and duration of the first two segments of the timedrawdown curve are reported by Neuman (1972) to be largely controlled by the parameter $\sigma=\left(S_{e} b\right) / S_{y}$; where $b$ equals the aquifer thickness. The smaller the value of $\sigma$, the more pronounced the effects of gravity drainage (i.e., the second segment), become. As $\sigma$ approaches 0 , the first segment disappears leaving only the second and third segments of the curve. Conversely, as $\sigma$ 
approaches infinity, the second segment vanishes and the third segment becomes coincident with the first segment of the time-drawdown curve.

This characteristic unconfined aquifer test behavior displayed during constant-rate pumping tests is shown in Figure 3.1 for observation we11, timedrawdown lata presented in Lohman (1972). Also shown are predicted Theis type curve responses that were generatied using the modified Novakowski (1990) program, based on aquifer property estimates and geometric relationship information also provided in Lohman (1972). Figure 3.1 clearly depicts the three-segment time-drawdown pattern previousiy discussed, and indicates thut early- (first segment) and late-time (third segment) behavior can be adequately described when $S_{a}$ and $S_{y}$ are usad, respectively, with the Theis equation.

Distance drawdown responses within an unconfined aq'ifer during a constant-rate pumping test can also be "visualized" in terms of the threesegmented response pattern described above. Gambolati (1976) states that at any time during testing, three cylindrical regions around the sicress well can be recognized within the aquifer. Within the inner region, flow is domilated by radial flow conditions for which the Theis solution is valid using a storativity value equal to $S_{e}+S_{y}$. In the middle region, ground-water flow components are both horizontal and vertical (i.e., the delayed-yield flow region), for which the Theis solution is not valid. In the outer region, ground-water flow is predominantly radial with the Theis solution valid using a storativity value equal to its elastic storage component $\left(S_{\theta}\right)$.

The cylindrical, vertical boundaries separating the three "idealized" regions propagate laterally with time away from the stress well location. At the beginning of the test, however, the boundaries are coincident at the well location, with only the third region (i.e., radial flow with storativity equal to $S_{e}$ ) existing and surrounding the well. Gambolati (1976) concludes that an unconfined aquifer responds like an artesian (confined aquifer) at the beginning of the test, and at any time during the test there exists an outer region surrounding the stress well that reacts elastically like an artesian aquifer. 


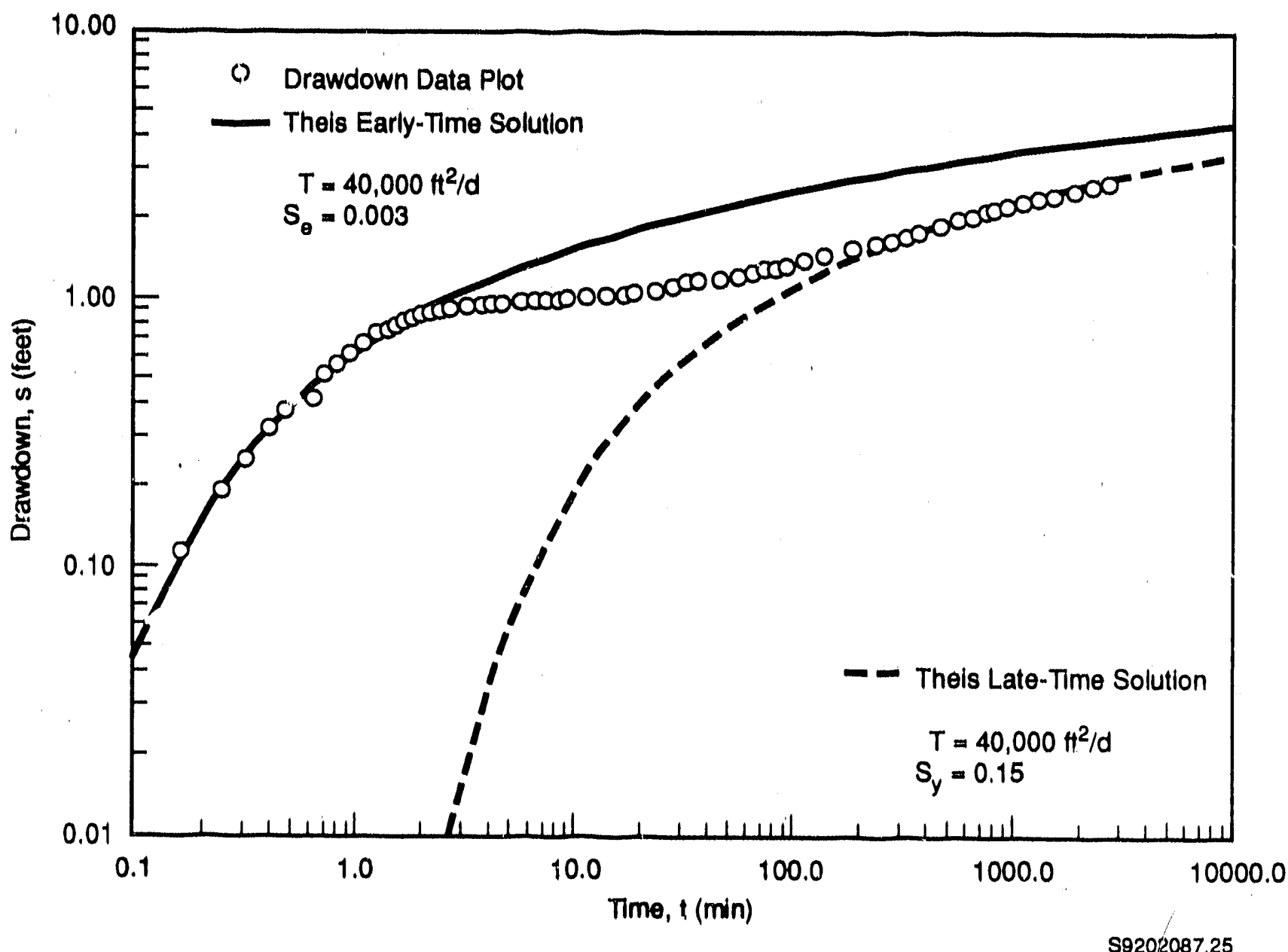

FIGURE 3.1. Characteristic Time-Drawdown Behavior for Unconfined Aquifer Conditions, During a Constant-Rate Pumping Test. (Test data taken from Lohman 1972).

On the basis of the preceding discussion, slug interference tests are expected to provide valid characterization information for test intervals that exhibit confined and semi-confined conditions, and for unconfined aquifers that display test responses that are reflecilve of time-drawdown behavior that is not significantly influenced by delayed-yield (i.e., gravity flow/vertical flow components) effects. Slug interference tests, however, would not be expected to provide valid hydrautic characterization results for sma11 test 
intervals at the water-table surface. This is due to conditions imposed by the presence of a free-surface boundary, and the damping effect imposed by the water table.

To be successfully analyzed with existing analytical methods (i.e., the computer program presented in Novakowski, 1990), the slug peak or central slug interference "hump" should not be significantly affected by delayed-yield test behavior. The presence of delayed-yield behavior can be discerned by converting the recorded siug test data to an equivalent head response that would be observed for a constant-rate pumping test. Conversion of slug test response data to equivalent head values associated with constant rate tests can be accomplished following the transformation procedure described in Peres, et al. (1989). The presence of delayed-yield behavior can then be assessed using pressure derivative analysis of the equivalent head response. A more detalled description of the conversion procedure and use of pressure derivative diagnostic methods is presented later in Section 4.4 .

\subsubsection{Partial Penetration and Vertical Anisotropy}

The theoretical basis for the program presented in Novakowski (1990) assumes that the stress and observation wells completely periatrate a homogeneous and isotropic aquifer. The program, therefore, cannot be rigorously used to analyze test results having conditions of partial well penetration and vertical anisotropy (i.e., the ratio of vertical to horizontal hydraulic conductivity). These conditions can exert discernable effects and cause departure of test responses from those based on fully penetrating wells within homogeneous, isotropic aquifers.

The effects of partial penetration cause distortion of the radial flow/ equipotential pattern that would normally develop during testing. within a homogeneous, isotropic aquifer surrounding a fully penetrating stress we 11. To illustrate its effect, Figure 3.2 shows the areal deviation in drawdown equipotential lines and flow lines that develop during a constant rate pumping test for a stress well that penetrates the lower 30 percent of a confined aquifer. As shown, partial penetration effects cause additional drawdown to occur with in the surrounding screened depth interval section of the aquifer, and less drawdown to occur within the non-screened aquifer section, i.e., the 


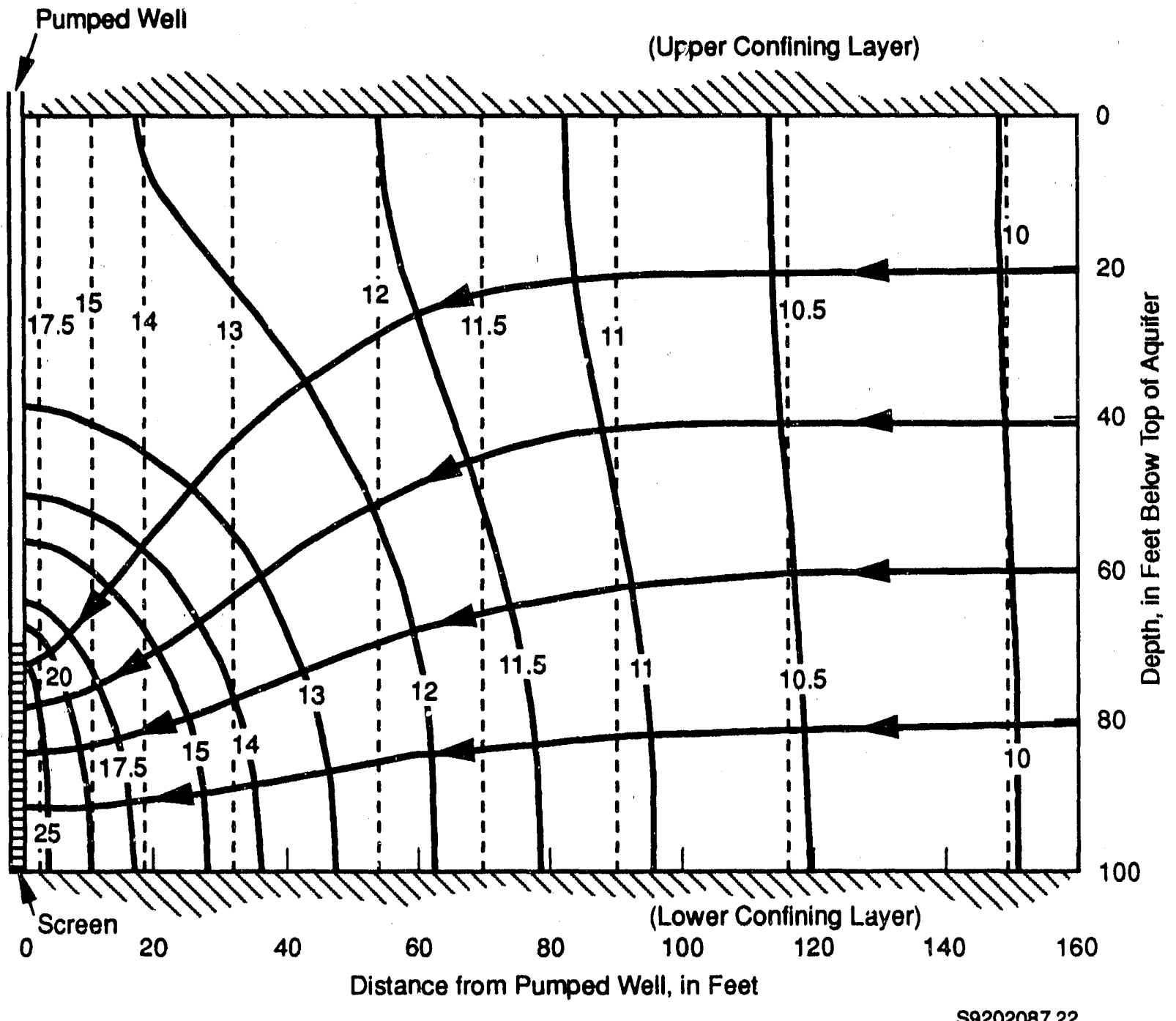

59202087.22

..... Equipotential lines developed for a fully penetrating stress well.

Equipotential lines developed for a partially penetrating stress well.

Ground-water flow lines.

FIGURE 3.2. Affects of a Partially Penetrating Pumping Well Completed in the Lower 30 Percent of a Confined Aquifer. (Adapted from Weeks 1969).

upper 70 percent of the aquifer. Deviations induced by partial penetration are more significant near the stress well and diminish with distance. Hantush 
(1961) states that the flow pattern during testing is essentially radial for observation well distances $\geq 1.5$ times the aquifer thickness; and for practical purposes equations based on fully penetrating stress wells (e.g., Theis equation) provide sufficiently accurate results for observation well distances as small as the aquifer thickness (i.e., $r / b=1$ ). This is provided that $u$ $<0.1(r / b)^{2}$; where $u=\left(r^{2} S\right) / 4(T t)$.

For observation wells located within a ratio distance of $r / b \leq 1.5$, the effects of partial penetration during tests can be accounted for following techniques presented by Weeks $(1964,1969)$, which are based on relationships originally presented in Hantush (1961). The correction methods were developed for constant-rate pumping tests, however, they are assumed to be applicable for slug interference test response as described in Cooper et a1. (1967) and Novakowski (1990); since these methods are based on the Theis equation.

Weeks (1969) states that the effects of vertical anisotropy also tend to amplify the drawdown deviations caused by partial penetration. Because of the presence of stratification that is evident to some degree in most sediments, vertical anisotropy would be expected to influence test results obtained within sedimentary aquifers. Neuman (1972) also reports that for most sedimentary unconfined aquifers, where the vertical anisotropy ratio is less than 1 (i.e., $K_{z} / K_{h}<1$ ), the effects of elastic storage and delayed yield (i.e., gravity drainage, as discussed in Section 3.2.1) are accentuated during the aquifer test response.

Hantusin (1964) reports that at a given distance, $r$, from a partially penetrating stress well, the effects of anisotropy would be the same as that at the distance $r\left(K_{z} / K_{h}\right)^{1 / 2}$ within an equivalent isotropic aquifer; where $K_{z}=$ vertical hydraulic conductivity, and $K_{h}=$ horizontal hydraulic conductivity. The effects of vertical anisotropy, then, can be accounted for using this relationship, if the ratio of vertical to horizontal conductivity is known or can be estimated for the test formation.

On the basis of the preceding discussion, slug interference tests can provide valid characterization information for test intervals that have partially penetrating stress wells and exhibit anisotropic behavior. This is provided that corrections are applied to observation wells within a radial 
distance less than an aquifer thickness (i.e., $r / b<1$ ) away from the stress well (following procedures provided in Weeks 1964, 1969), and the vertical anisotropy within the aquifer is known and corrected for using the relationship presented in Hantush (1964).

\subsubsection{Transmissivity}

Figure 3.3 shows the predicted response of a slug test at the stress well for transmissivities $\left(T\right.$ ) ranging between $10^{3}$ to $10^{5} \mathrm{ft}^{2} / \mathrm{d}$ (Note: $T=\mathrm{Kb}$; where $K=10^{2}$ to $10^{4} \mathrm{ft} /$ day and $b=10 \mathrm{ft}$ ). As indicated, only slug test responses for transmissivities below $10^{4}$ can be discerned at the stress we 11 for a storativity value of $10^{-3}$ (i.e., assuming a $1 \mathrm{~s}$ detection $1 \mathrm{imit}$ ). This corroborates the upper limit reported by Lohman (1972) for slug testing (i.e., single-well tests) of approximately $7,000 \mathrm{ft}^{2} / \mathrm{d}$. However, because of adverse borehole conditions (e.g., turbulent flow, etc.) and data recording

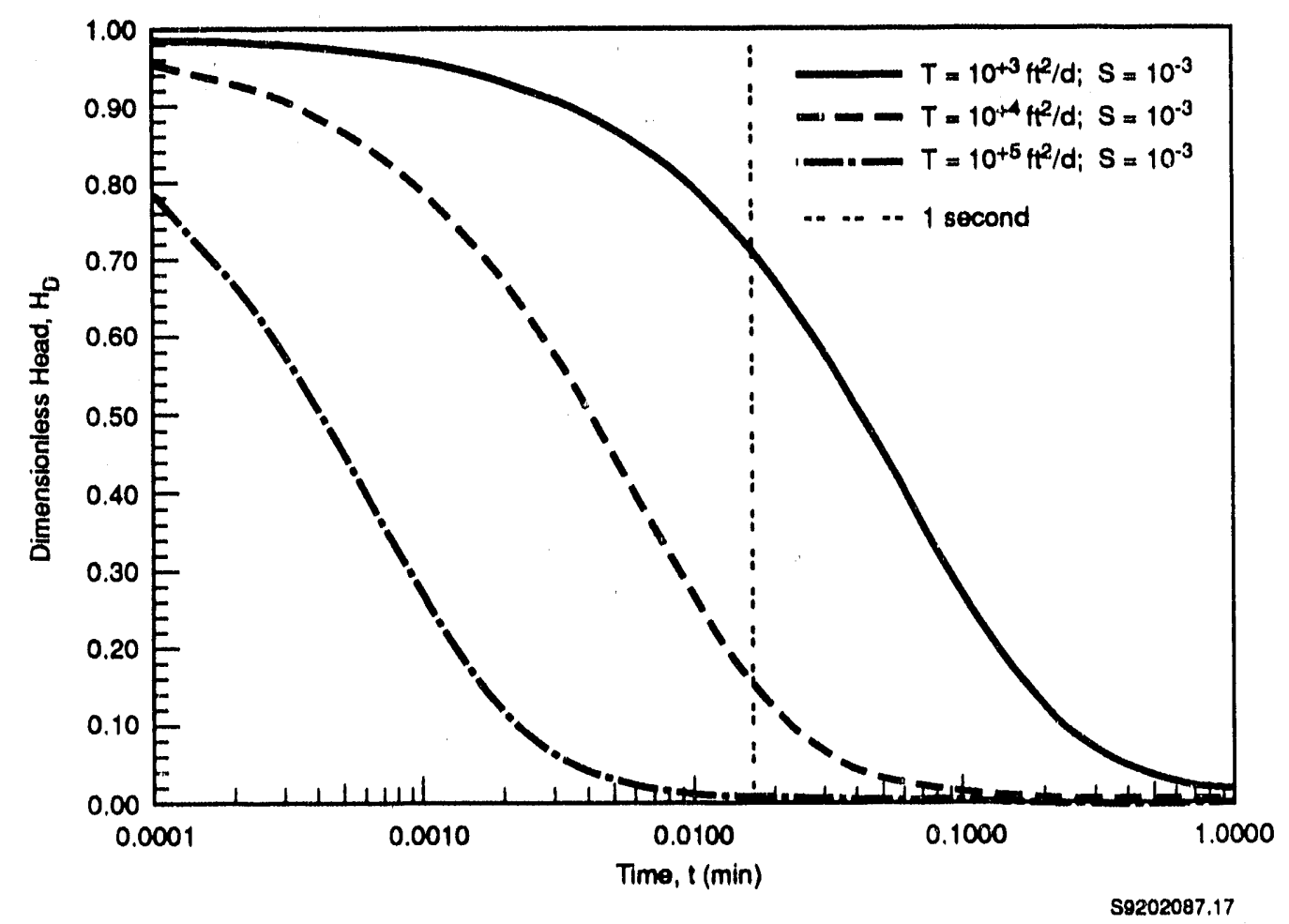

FIGURE 3.3. Predicted Slug Test Response at the Stress Well for a Transmissivity Range $10^{3}$ to $10^{5} \mathrm{ft}^{2} / \mathrm{d}$, and a Storativity of $10^{-3}$ 
requirements imposed by higher transmissivity formations, a practical upper range for slug testing at single wells is about $10^{3} \mathrm{ft}^{2} / \mathrm{d}$.

While analyzable slug test responses at the stress well are 1 imited to test formations with transmissivities of $10^{3} \mathrm{ft}^{2} / \mathrm{d}$ or less, Figure 3.4 indicates that slug interference responses for transmissivities of $10^{5} \mathrm{ft}^{2} / \mathrm{d}$ or less are readily discernible at a distance of $10 \mathrm{ft}$ from the stress we 11 location. As indicated in the figure, for a given observation point location, transmissivity has no effect on the magnitude of test response, but does exert a strong influence on the predicted slug interference response time, causing the interference response to shift horizontally on the plot. High test zone transmissivities are associated with fast test responses, while lower test interval transmissivities are associated with lagged interference responses.

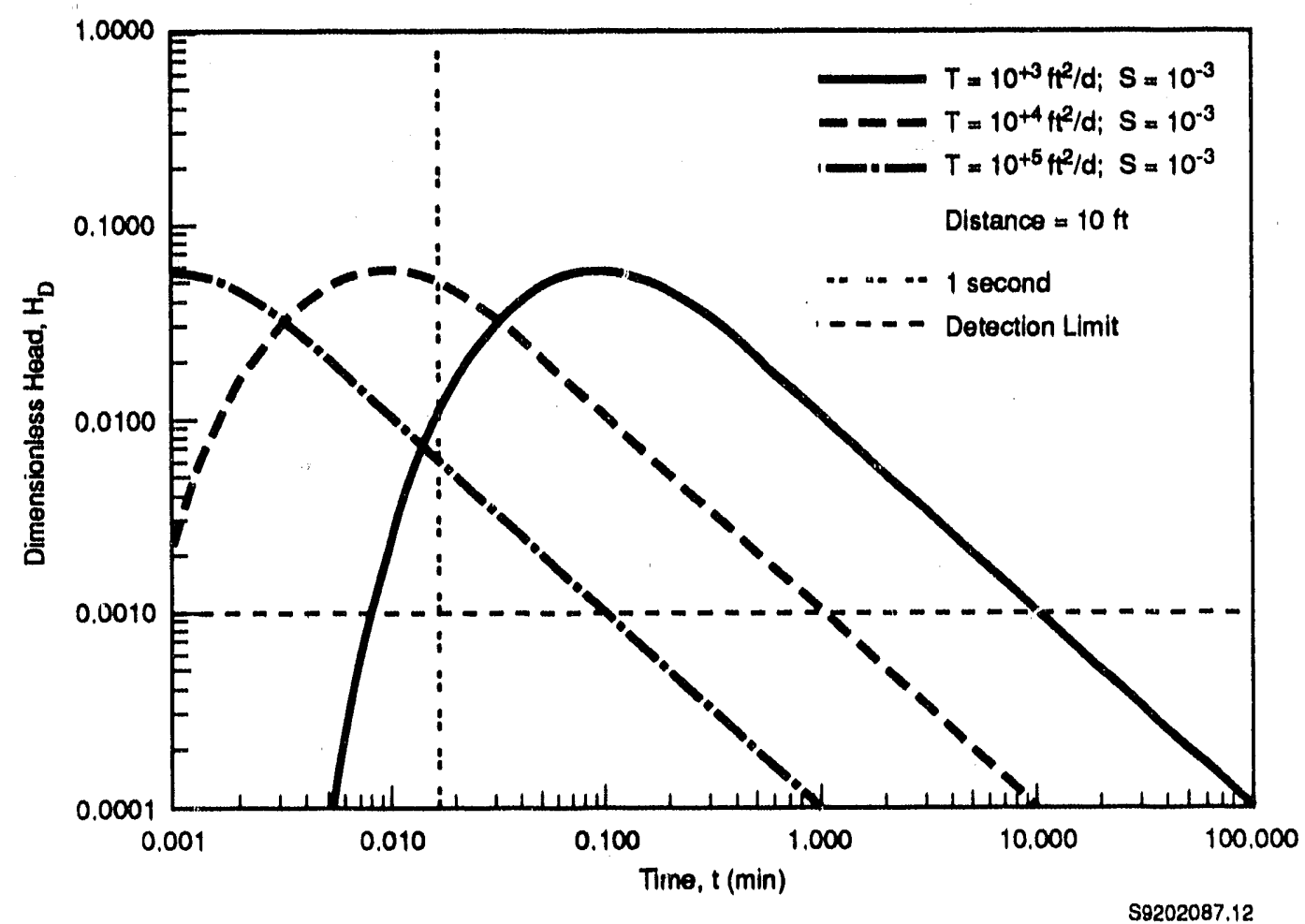

FIGURE 3.4. Predicted S7ug Interference Response at a Radial Distance of $10 \mathrm{ft}$ from the Stress We1l, for a Transmissivity Range $10^{3}$ to $10^{5} \mathrm{ft}^{2} / \mathrm{d}$ and a Storativity of $10^{-3}$ 


\section{2 .4 Storativity}

Storativity, $S$, is a dimensionless hydrologic parameter that indicates the volume of water released from or taken into storage per unit surface area of the aquifer per unit change in head. For confined aquifers the storativity is primarily related to the compressibility of the aquifer matrix and elasticity of the contained ground water. Because compressibility and elasticity values for aquifer materials and water, respectively, are inherently smal1, storativities for confined aquifers are low and generally range between $10^{-5}$ and $10^{-3}$ (Heath 1983). In contrast, storativities for unconfined aquifers consist of two components; an elastic component, $S_{e}$, (as described previously for confined aquifers) and the specific yield, $S_{y}$. Because of the small value associated with the elastic storage component, long-term production of ground water from unconfined aquifers is primarily determined by its specific yield, which is reported to usually range between 0.1 and 0.3 (Heath 1983). The effect of the elastic storage component on unconfined aquifer response, however, is reported to play an important role in test response within unconfined. aquifers and must be accounted for (e.g., Gambolati 1976; Neuman 1974, 1979).

Previously reported slug interference tests have been limited primarily to tests conducted in confined aquifers and/or fractured rock formations, with storativity values $\leq 10^{-4}$. These conditions are not representative of hydrologic conditions for the unconfined aquifer at the Hanford Site. In this section the affects of higher formation storativity, which are more representative of reported unconfined aquifer conditions at the Hanford Site (i.e., between $10^{-1}$ a.ld $10^{-4}$ ) are examined; both for the stress and observation well locations.

Figure 3.5 shows the predicted response of a slug test at the stress well for a transmissivity of $10^{3} \mathrm{ft}^{2} / \mathrm{d}$ for various values of storativity (S), ranging from $10^{-1}$ to $10^{-4}$. As indicated in the figure, type-curve responses for storativity values $10^{-2}$ and less are very similar in shape. This similarity in type-curve shape prompted Cooper et a1. (1967) to conclude that:

"... because the matching of the data plot to the type curves depends on the shapes of the type curves, which differ only slightly when $\alpha$ differs by an order of magnitude, a determination of $S$ by this method has questionable reliability." 


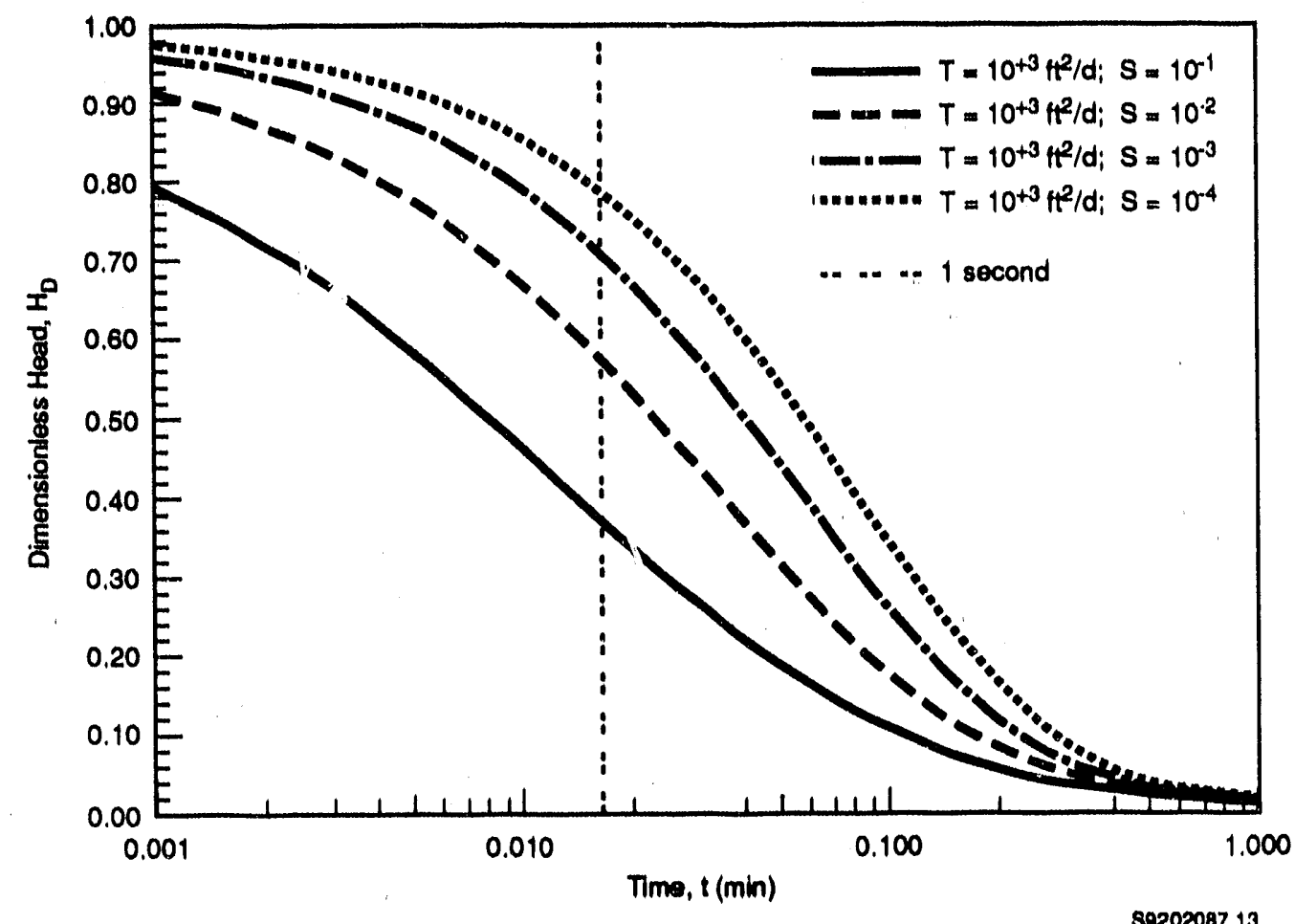

FIGURE 3.5. Predicted Slug Test Response at the Stress Well for a Storativity Range $10^{-1}$ to $10^{-4}$, and a Transmissivity of $10^{3} \mathrm{ft}^{2} / \mathrm{d}$

The ambiguity in determining the storativity is greatly reduced, however, when a slug interference test is observed in a nearby observation we 11 . Figure 3.6 shows the predicted slug test response at a radial distance of $10 \mathrm{ft}$ from the stress wel1, for a storativity range of $10^{-1}$ to $10^{-4}$ and a transmissivity of $10^{3} \mathrm{ft}^{2} / \mathrm{d}$. In contrast to the slug response at the stress we11, the shape of the slug interference response (i.e., the amplitude of the slug response) at the observation well is strongly influenced by the storativity of the aquifer. For this reason, slug interference testing can be utilized to obtain a more precise estimate of storativity for the interval tested.

\subsubsection{Radial Distance}

Figure 3.7 shows the predicted maximum slug interference test response as a function of radial distance from the stress well location: for a storativity, $S$, range $10^{-1}$ to $10^{-4}$, and a wellbore radius, $r_{w}$, of $0.3333 \mathrm{ft}$. As 


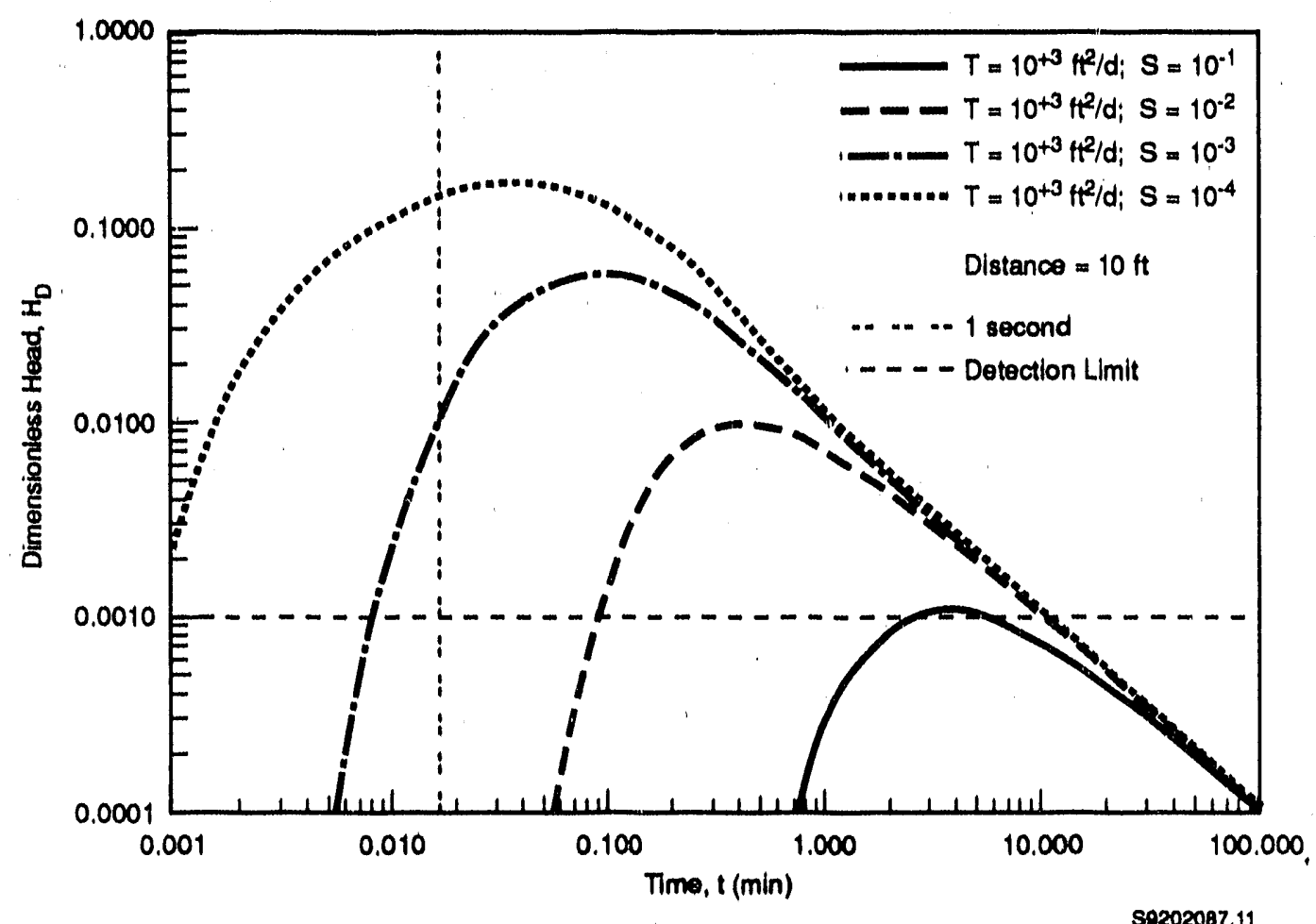

FIGURE 3.6. Predicted Slug Interference Response at a Radial Distance of $10 \mathrm{ft}$ from the Stress We11, for a Storativity Range $10^{-1}$ to $10^{-4}$ and a Transmissivity of $10^{3} \mathrm{ft}^{2} / \mathrm{d}$

expected, the figure shows that the ability to detect a response is enhanced the closer the observation well is located to the stress well and the lower the storativity value is of the geologic material. Information presented in the figure also indicates that for the storativity range considered to be representative of most unconfined aquifer conditions on the Hanford Site (i.e., $10^{-2}$ to $10^{-3}$ ), that discernable sluy interference responses should be observable to maximum distances of between 30 to $100 \mathrm{ft}$ surrounding the stress wel1.

It should be restated here that transmissivity of the test formation does not influence the slug amplitude observable with distance from the point of stress application. Transmissivity does, however, (as discussed in Section 3.2.3) control how rapidly the slug response propagates away from stress wel1. 


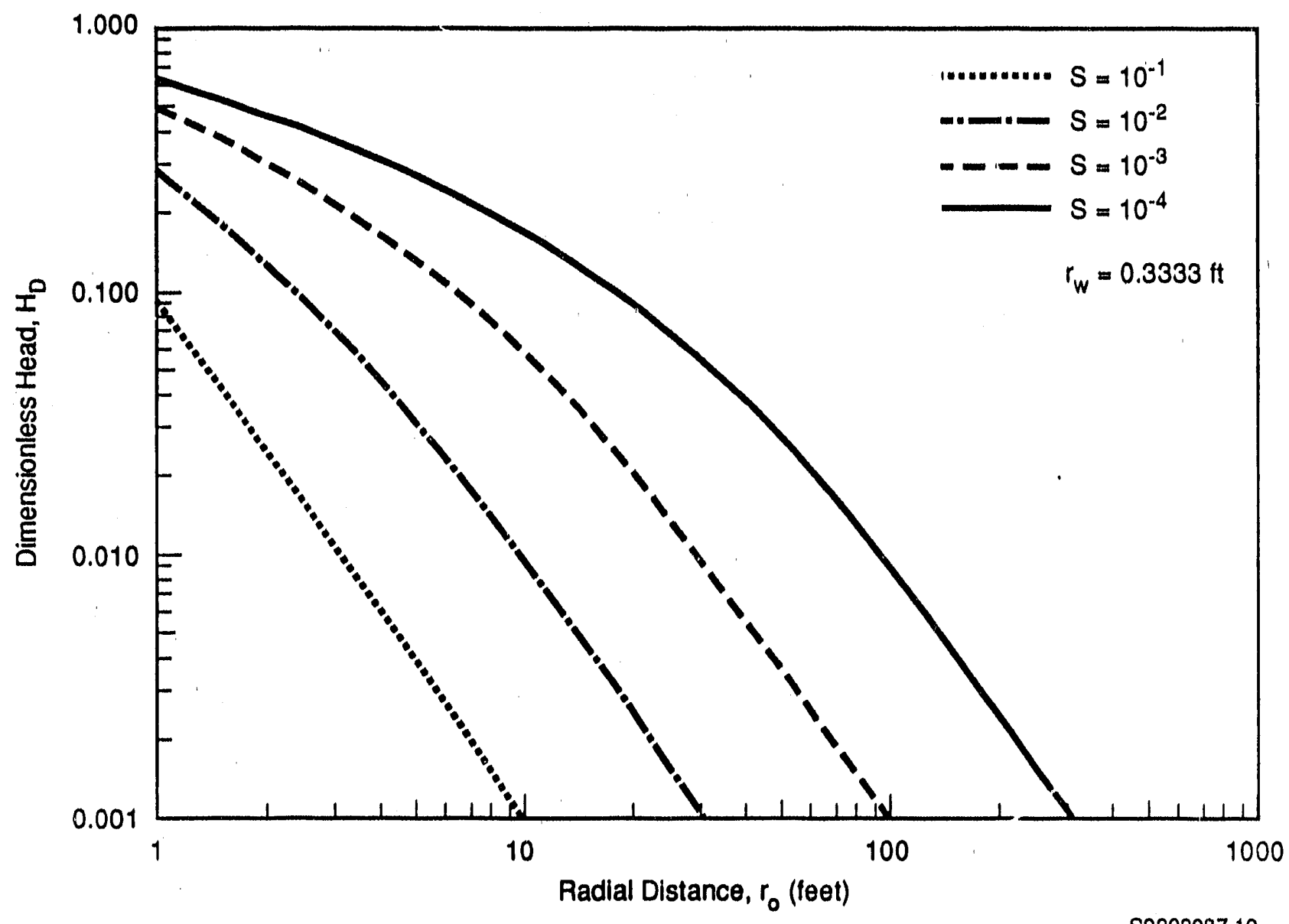

59202087.10

FIGURE 3.7. Predicted Maximum Slug Interference Response as a Function of Radial Distance from the Stress Well Location, for Storativity Values, $S, 10^{-1}$ to $10^{-4}$

\subsubsection{Observation Wellbore Storage}

The previous discussion assumes that the wellbore storage of the observation we11, $C_{D_{0}}$, is negligible in comparison to that of the stress we11, $C_{D_{s}}$ (i.e., $C_{D_{0}} \leq 0.1 C_{D_{s}}$ ). Significant observation wellbore storage tends to cause the well response to be lagged (i.e., delayed) and attenuated from the predicted response, which assumes $C_{D_{0}}$ is negligible. This effect is shown diagrammatically in Figure 3.8. As indicated by Novakowski (1989), the shape of the curves for $C_{D_{0}}$ equai to $C_{D s}$ are more "peaked and distinctive" in comparison to the curves where $C_{D_{0}}$ is negligible. Figure 3.8 also indicates, 


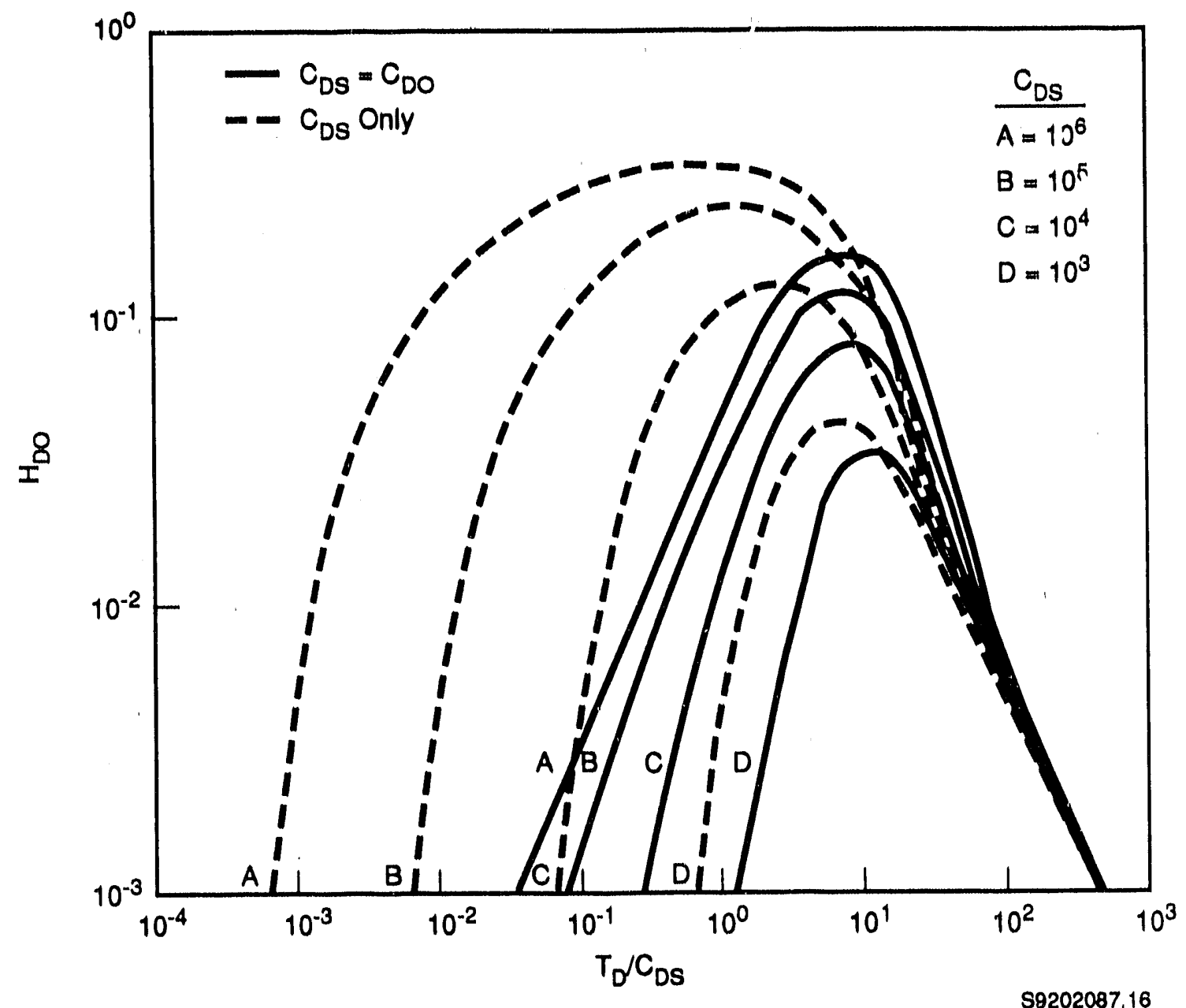

FIGURE 3.8. Comparison of Predicted Slug Interference Response for a Family $C_{\text {Ds }}$ Type Curves, for the Case Where $C_{D_{0}} \ll C_{D s}$ and $C_{D_{0}}=C_{D_{s}}$.

however, that the difference in response curves diminishes appreciably as the wellbore storage value at the stress we11, $C_{D s}$, decreases. This suggests that only minor differences in predicted and observed responses would be expected for the wellbore storage values considered in this study (i.e., $C_{D s} \approx 1$ to $\left.10^{3}\right)$.

Novakowski (1989) presents a graphical method for analyzing slug interference responses for the case where wellbore storage at the observation well is not important (i.e., $C_{D_{0}} \ll C_{D s}$ ), as well as significant (i.e., $C_{D_{D}}=C_{D s}$ ). 
The reader is instructed to consult Novakowskt (1989) for a detalled description of the analysis procedure. It should noted that Novakowski's graphical method could not be used to analyze results of the fleld test evaluation presented in Section 4.4 , because the graphical type curve relattonships did not cover conditions that existed for the test.

\subsection{TEST METHOD CONSIDERATIONS}

\subsubsection{Test Desian}

To serve as guidance for the design of field siug interference tests, a set of type-curve plots are presented in this report section. The test design type curves are expressed in dimenstonless parameters to provide a broader means of application. To factlitate their use, the following definttions for the dimensionless parameters are provided:

Dimensionless Radial Distance

$$
R_{D}=r_{0} / r_{w}
$$

Dimensionless Time

$$
T_{D}=(T t) /\left(S r_{w}{ }^{2}\right)
$$

Dimensionless Wellbore Storage

$$
C_{D}=C_{s} /\left(2 \pi r_{w}^{2} S\right)
$$

where,

$$
C_{s}=\pi r_{c}^{2}
$$

Dimensionless Head, $H_{D}$, is defined in Equation (1), and for minimum detection limit assessment was arbitrarily selected to be equal to 0.001 .

Figure 3.9 shows the predicted maximum dimensionless head response with radial distance away from the stress well for the range of wellbore storage 


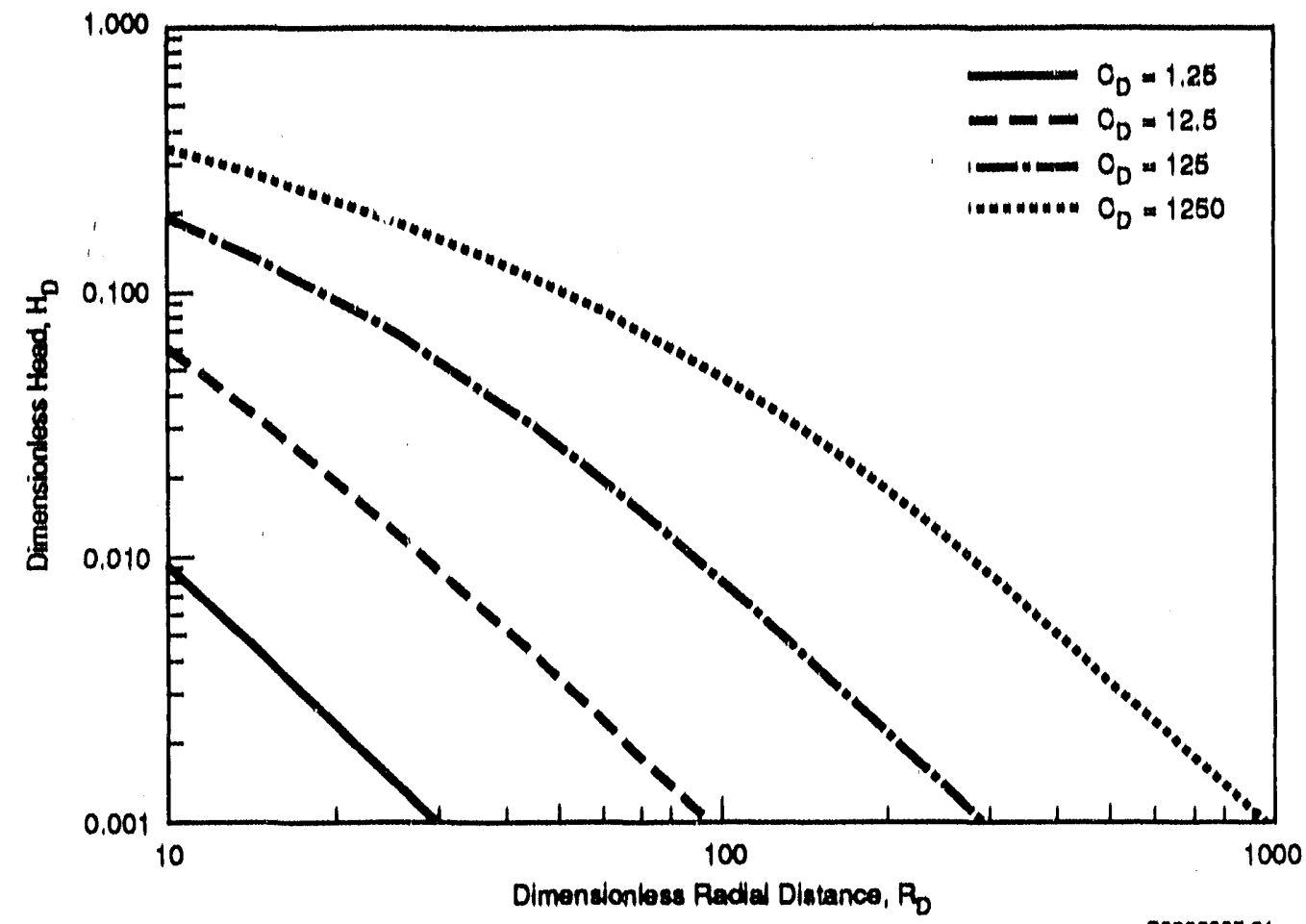
EIGURE 3.9. $\begin{aligned} & H_{0} \text { Versus } R_{D} \text { Type Curves for } C_{D} \text { Values: } 1.25,12.5,125 \text {, } \\ & \text { and } 1250\end{aligned}$

constants considered in this study (i.e., $C_{D}=1.25$ to 1250 for $S=10^{-1}$ to $10^{-4}$ ). For the well and casing radti listed in Table 1 , the wellbore storage constant range represents test interval storativity values of $10^{-1}$ to $10^{-4}$, respectively (see Appendix A). The maximum observable response that can be expected at a prescribed observation well distance can be obtained by selecting the most representative $C_{D}$ curve for the intervening test formation, and multiplying the indicated dimensionless head response by the estimated stress level to be applied at the stress we11. For example: for a stress well radius of $4 \mathrm{in}$., at an observation well distance of $25 \mathrm{ft}$, a $C_{D}$ type curve of 125 (i.e., a storativity of $10^{-3}$ ) and an applied stress level of $30 \mathrm{ft}$ of fluid at the stress we11, a predicted observation well response of about $0.4 \mathrm{ft}$ is indicated.

Figure 3.10 presents the same $C_{0}$ type curves as a function of dimensionless radial distance, $R_{0}$, versus the ratio of dimensionless time, $T_{0}$, and the 


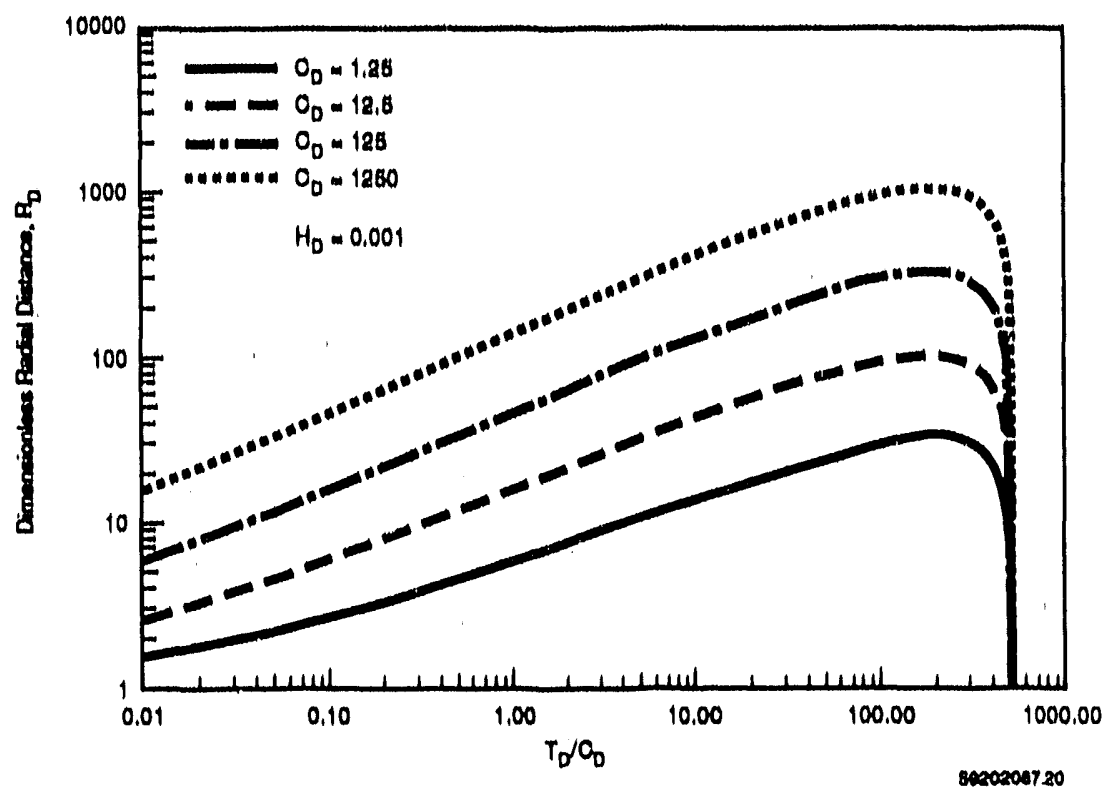

EIGURE 3.10. $R_{D}$ Versus $T_{D} / C_{D}$ Type Curves for $C_{D}$ Values: $1.25,12.5,125$,

dimensionless wellbore storage, $C_{D}$, for a minimum observable response (f.e., $\left.H_{D}=0.001\right)$. Figure 3.10 can be utilized to predict the duration and the time of observation of the slug interference at the point of observation. The predicted time of observation for the siug interference response can be obtained by selecting the assoctated $T_{D} / C_{D}$ value for the appropriate $C_{D}$ curve and observation we 11 distance. As indicated, each $C_{D}$ curve intersects the selected $R_{0}$ distance twice. The first is for the initial arrival time of the slug interference response (i.e., when it first is observable), and the second indicates the time when the slug interference response can no longer be discerned. The difference between the two times provides the duration of the slug interference response at the point of observation. Estimated times for the two points of intersection on the type curves can be obtained by multfplying the derived $T_{D} / C_{0}$ values by the approprtate $C_{0}$ curve used, and then solving for time, $t$, utilizing a rearranged form of the dimensionless time, $T_{0}$, equation presented in Equation ( 5 ). 
As an example of using Figure 3.10, the following is provided: For a stress well radius of $4 \mathrm{in.}$, a radial distance of $25 \mathrm{ft}$, and a $C_{0}$ value of 125, assoclated $T_{0} / C_{0}$ values of about 3.1 and 490 are indicated. This ind 1 cates $T_{D}$ values of 388 and 61,250 , respectively. To calculate the associated response' times, a transmissivity of $1,000 \mathrm{ft}^{2} / \mathrm{d}$, a storativity value of $10^{-3}$, and well radius of $4 \mathrm{in}$. are assumed for this example. Utilizing these parameter estimates and rearranging Equation (5) provides the following estimates: arrival time of slug interference $=4 \mathrm{~s}$; termination of observable slug interference $=588 \mathrm{~s} ;$ and, slug interference duration $=584 \mathrm{~s}$.

For the purpose of describing the overall shape of the slug test response or for determining the time of the maximum observable slug interference, Figures 3.11(a) through 3.11(d) are provided for selected dimensionless radial distances of $30,75,150$, and 300 , respectively. For a stress well radius of $4 \mathrm{in}$., this is analogous to radial distances of 10, 25, 50, and $100 \mathrm{ft}$. To demonstrate their usage for determining the time of maximum slug interference, a radial distance of $25 \mathrm{ft}\left(R_{D}=75\right)$ and a $C_{D}=125$ are selected. As indicated in Figure 3.11(b), based on these specifled input parameters, a $T_{D} / C_{D}$ value of 17 is obtained. Utilizing the previously cited parameter estimates for transmissivity $\left(1,000 \mathrm{ft}^{2} / \mathrm{d}\right)$, storativity $\left(10^{-3}\right)$ and stress well radius (4 in.), and rearranging Equation (5) provides an estimate for arrival time of the maximum stress interference response of $20 \mathrm{~s}$.

\subsubsection{Test Method Initiation/Test Equipment}

The following recommendations are provided for obtaining the optimum results in performing slug interference tests in the field:

1. To establish the response to external stresses (e.g., atmospheric pressure changes, drilling activities, etc.), it is recommended that the observation well test equipment be installed prior to initiation of drilling and/or at least one week prior to initiation of hydrologic testing activities.

2. To maximize the observed slug interference response, efforts should be made to minimize wellbore storage within the observation well. This can best be achieved by isolating the observation well test interval with a downhole straddle packer/transducer system and downhole shut-in tool device (see Figure 2.1). 


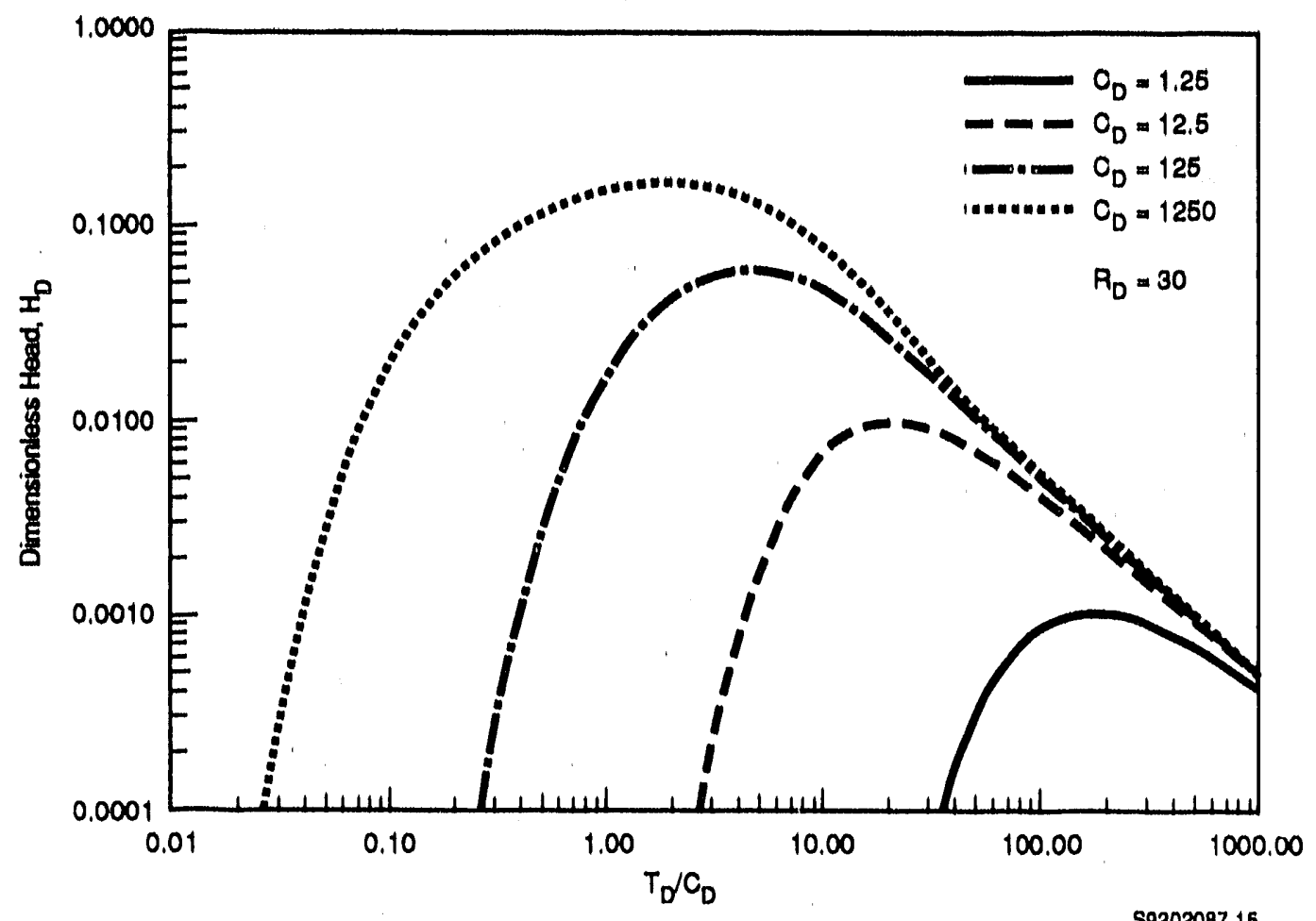

(a)

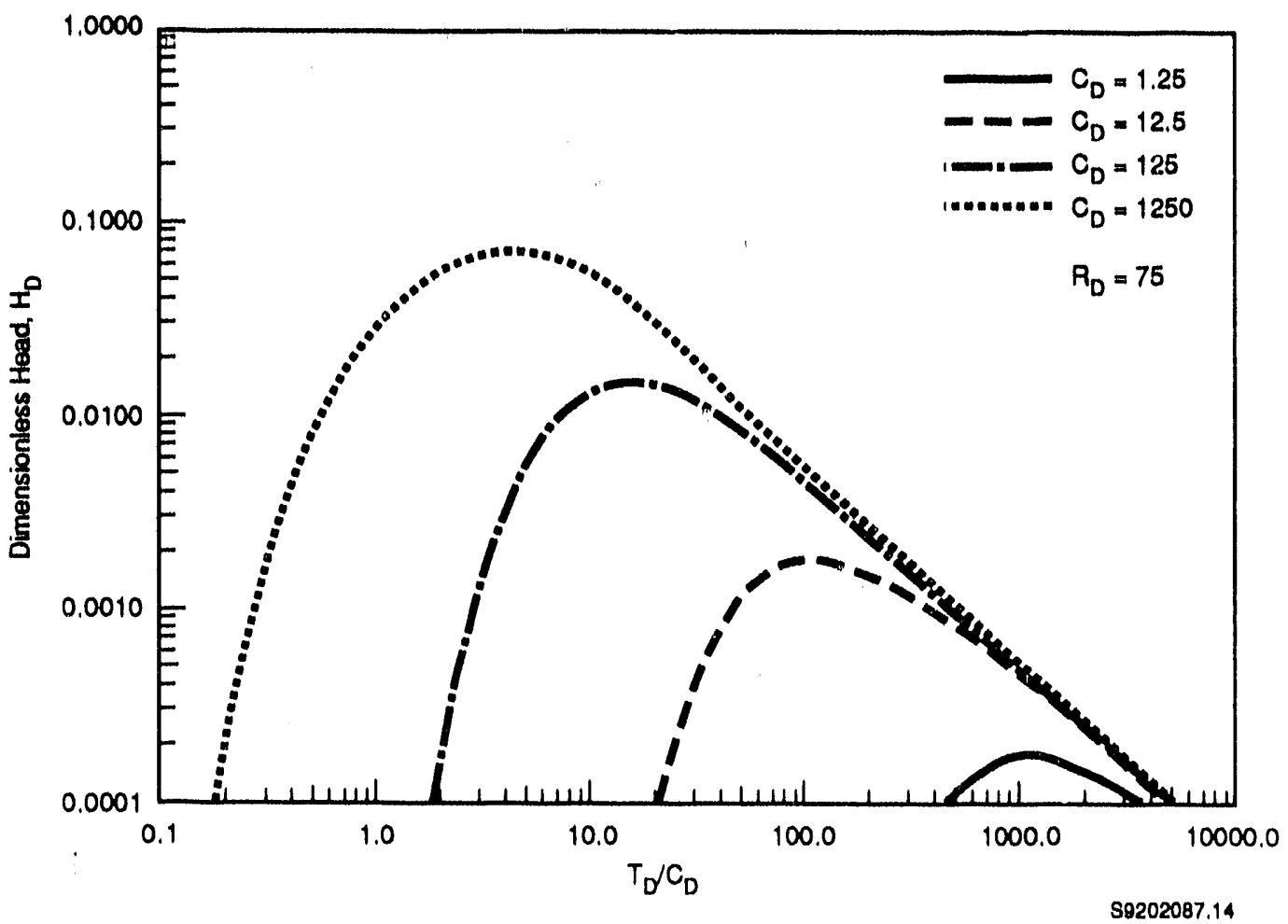

(b)

FIGURE 3.11. $H_{0}$ Versus $T_{D} / C_{0}$ Type Curves for (a) $R_{D}=30$ and (b) $R_{D}=75$ 


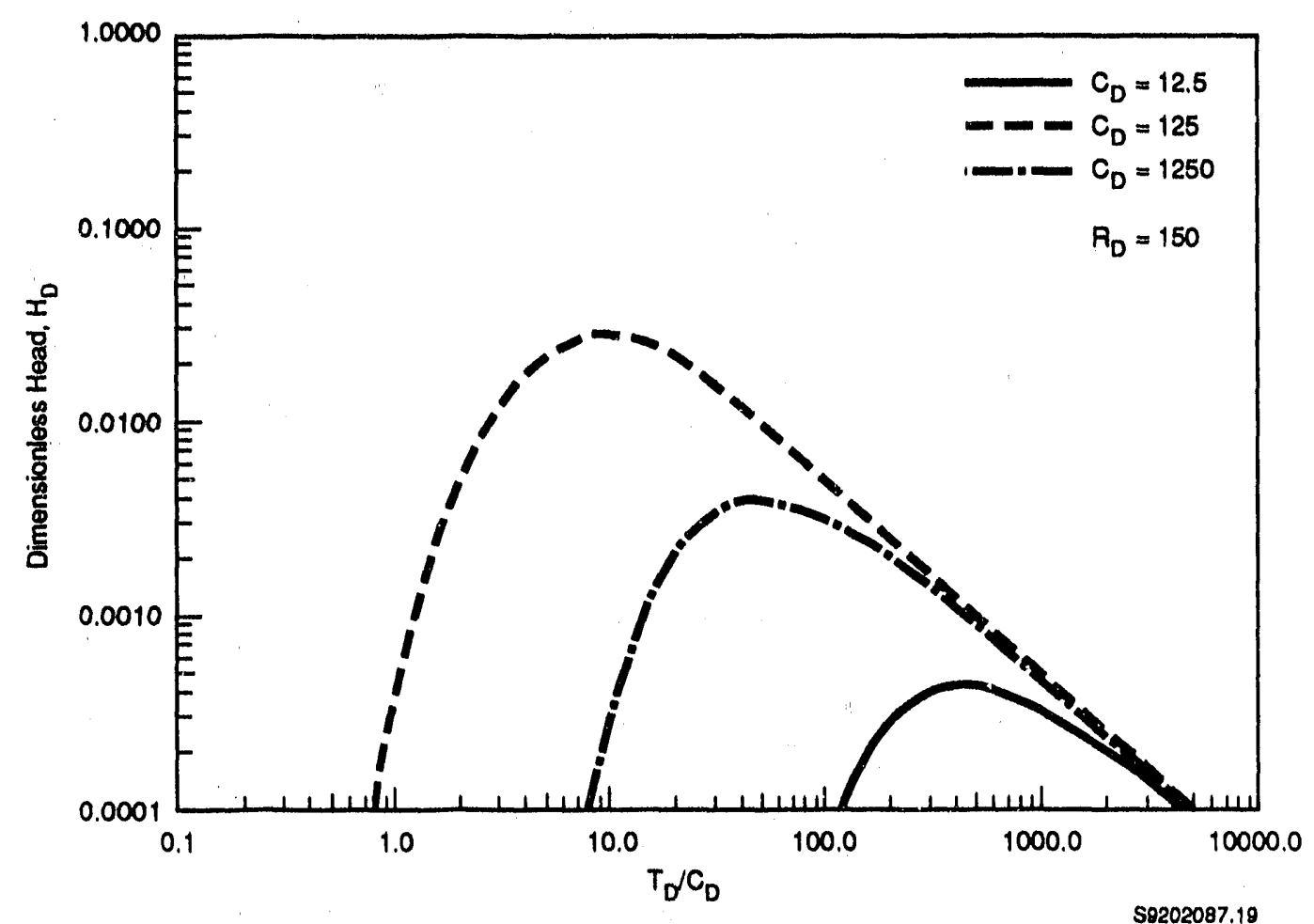

(c)

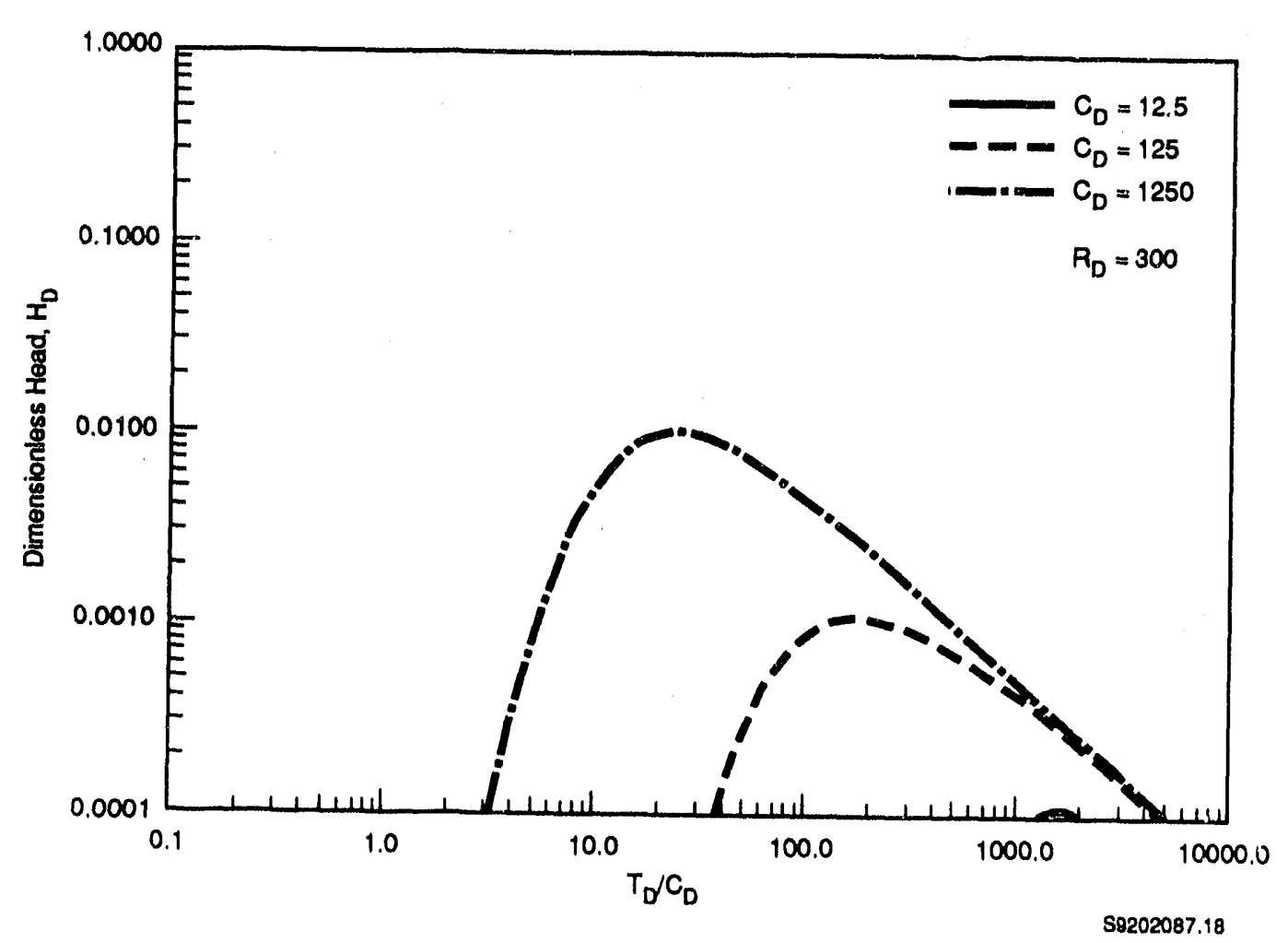

(d)

FIGURE 3.11. $\quad H_{D}$ Versus $T_{D} / C_{D}$ Type Curves for $(c) R_{D}=150$ and (d) $R_{D}=300$ 
3. Wells with larger wellbore storage (i.e., larger well radii) within a well cluster site should be selected as stress well locations. No downhole equipment that would measurably decrease the wellbore storage (e.g., downhole packer system) should be employed, if possible, within the stress well.

4. High resolution pressure detection equipment and a fast data acquisition system installed at the observation well will enhance the detection of the slug interference response.

5. Stress levels equal to or greater than $25 \mathrm{ft}$ of water (i.e., above or below static conditions) are recommended for propagating the slug test response from the stress well site.

6. For stress wells with static fluid columns that are $25 \mathrm{ft}$ or greater above the screened interval (see Figure 2.1a), slug withdrawal tests are recommended. Water columns within the well can be lowered by increasing the air pressure in the air column space above the water column (e.g., by using regulated compressed air bottles). Care should be exercised not to lower the water column level below the top of the screened interval. This would cause injection of air into the test formation. After a period of pressure equilibration (i.e., following air injection), the air pressure can be released, which initiates the slug withdrawal test.

7. For stress wells with static fluid columns that are within the screened interval (see Figure 2.1b), slug injection tests are recommended. For these situations a downhole packer (with preferably a 3- to 5-ft packer element) would be required to ensure that the injected water does not directly discharge into the unsaturated section exposed in the screened interval. Utilization of a downhole shut-in tool will allow the administering of a water column of prescribed height above static conditions (i.e., $25 \mathrm{ft}$ or greater). Opening the shut-in tool initiates the slug injection test. 


\subsection{EIELD TEST EVALUATION - TEST EXAMPLE}

Based on the favorable findings associated with the analytical assessment of the proposed test method (Phase 1), a field test evaluation (Phase 2) was conducted. The test site location selected had been previously hydrologically characterized. The following sections describe the field test facllity, test design, test equipment utilized, test method theoretical considerations, and field test evaluation and analysis.

\subsection{TEST SITE DESCRIPTION}

The slug interference test facility consisted of two existing wells (699-43-41E and 699-43-4IF), and a new well (699-43-41G) that was drilled during July and August 1991. The two existing wells were used as observation wells during the test evaluation. New well 699-43-41G was utilized as the stress well for inducing the slug stress that was monitored at the two nearby observation wells. Pertinent well location and construction information pertaining to the stress and observation wells is provided in Figure 4.1 and Tables 4.1 and 4.2 .

Construction as-builts for observation wells 699-43-41E and 699-43-41F, and temporary test completion at well 699-43-41G during the slug interference test are shown in Figures 4.2 and 4.3 , respectively.

\subsection{TEST EQUIPMENT}

\section{Observation Wells}

Observation wells (699-43-41E and 699-43-41F) were equipped with identical downhole test equipment. The downhole installation included the following elements as shown in Figure 4.3:

- 3.5-in. - 0.D., inflatable Baski packer, Model \# LD200 $3.5 " 6.0 " 2.0-S T D-30-E F A 10$,

- Seling Corporation single pressure probe (containing a 0 - 200 psia Paroscientific quartz pressure transducer),

- Packer setting cable, 


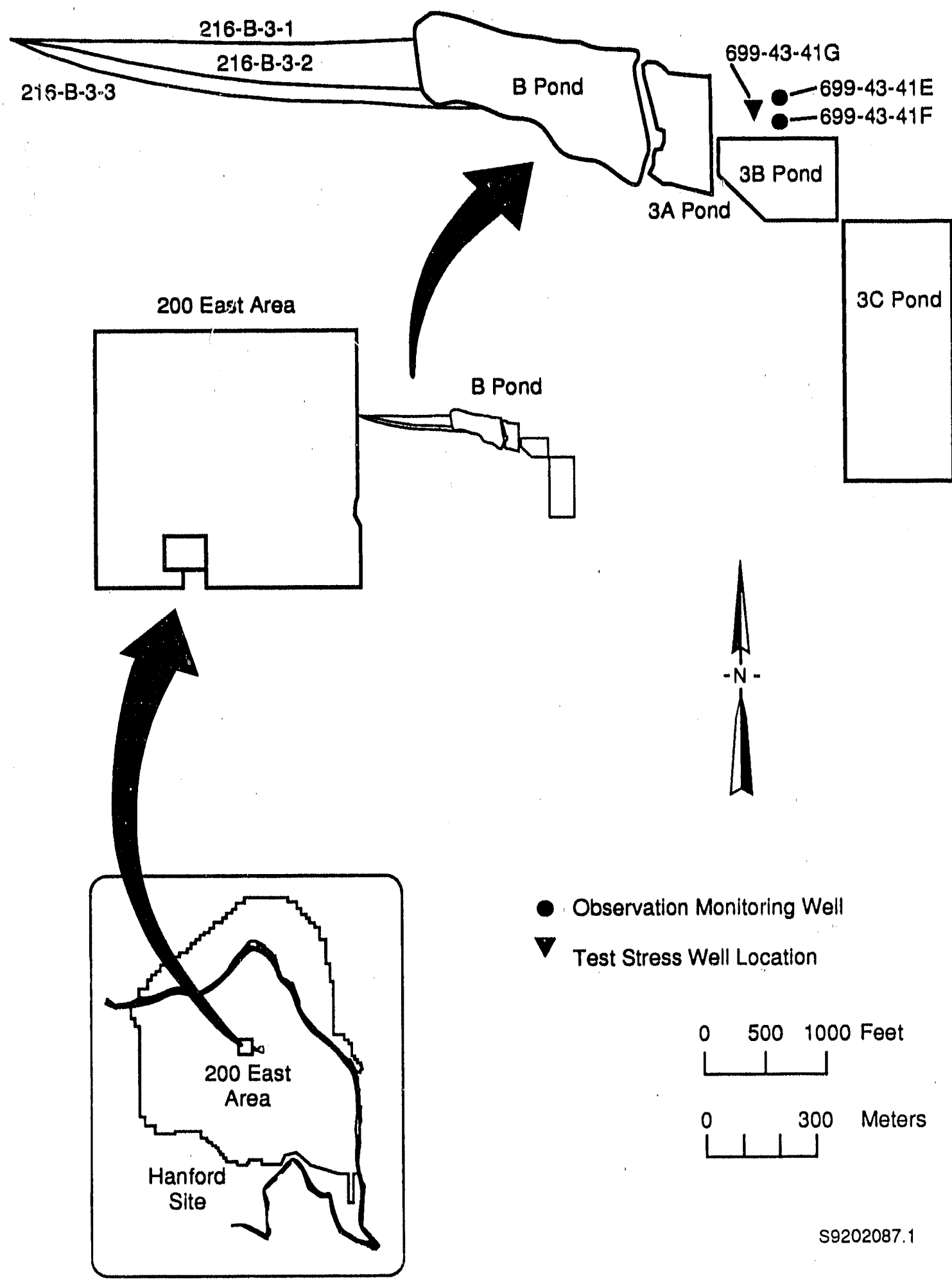

FIGURE 4.1. Location Map of STug Interference Test Facility 
IABLE 4.1. Pertinent Well Completion and Construction Information for Wells 699-43-41E, 699-43-41F, and 699-43-41G

\begin{tabular}{|c|c|c|c|c|}
\hline Well Designation & $\begin{array}{c}\text { Casing } \\
\text { Diameter } \\
\text { (in.) }\end{array}$ & $\begin{array}{l}\text { Casing } \\
\text { Depth } \\
(f t) \\
\end{array}$ & $\begin{array}{c}\text { Screen } \\
\text { Diameter } \\
\text { (in.) }\end{array}$ & $\begin{array}{c}\text { Screened } \\
\text { Interval } \\
(\mathrm{ft})\end{array}$ \\
\hline $699-43-41 E^{(a)}$ & 4.0 & 135.5 & 4.0 & $135.5-146.1$ \\
\hline $699-43-41 F^{(a)}$ & 4.0 & 165.3 & 4.0 & $165.3 \cdot 175.9$ \\
\hline $699-43-41 G^{(a, b)}$ & 10.0 & 162.7 & 8.0 & $162.7-172.8$ \\
\hline
\end{tabular}

(a) Depth interval designations for we11s 699-43-41E and 699-43-41F referenced from the brass cap surface control datum; we11 699-43-41G referenced from land surface.

(b) The casing and screened depch intervals indicated were valid only for the period of slug interference testing. The well was deepened and recompleted later.

TABLE 4.2. Calculated Distance Relationships Between Wells 699-43-41E, $699-43-41 \mathrm{~F}$, and 699-43-41G

\begin{tabular}{|c|c|c|c|c|c|}
\hline \multirow[b]{2}{*}{ Well Designation } & \multicolumn{2}{|c|}{$\begin{array}{c}\text { Hanford Site } \\
\text { Well Coordinates } \\
\end{array}$} & \multicolumn{3}{|c|}{$\begin{array}{c}\text { Calculated Horizontal Distance } \\
\text { To }\end{array}$} \\
\hline & $\begin{array}{l}\text { North } \\
(\mathrm{ft})\end{array}$ & $\begin{array}{l}\text { West } \\
(\mathrm{ft})\end{array}$ & $\begin{array}{l}699-43-41 E \\
(\mathrm{ft}) \\
\end{array}$ & $\begin{array}{l}699-43-41 \mathrm{~F} \\
(\mathrm{ft}) \\
\end{array}$ & $\begin{array}{l}699-43-41 \mathrm{G} \\
\frac{(\mathrm{ft})}{}\end{array}$ \\
\hline $699-43-41 E$ & $42,994.9$ & $40,723.0$ & - & 50.4 & 47.8 \\
\hline $699-43-41 F$ & $42,944.5$ & $40,720.9$ & 50.4 & - & 48.9 \\
\hline $699-43-41 G$ & $42,969.0$ & $40,763.2$ & 47.8 & 48.9 & - \\
\hline
\end{tabular}

- Packer inflation line, and

- 1/4 in. O.D., co-axial conductor cable.

The packer setting cable was used to install the inflatable packer immediately above the screened interval within each monitoring well. The packer was inflated using the packer inflation line and a surface, compressed air cylinder. Packer inflation pressures were within the manufacturer reported inflation specifications (i.e., differential pressure rating of approximately 200 psi). 


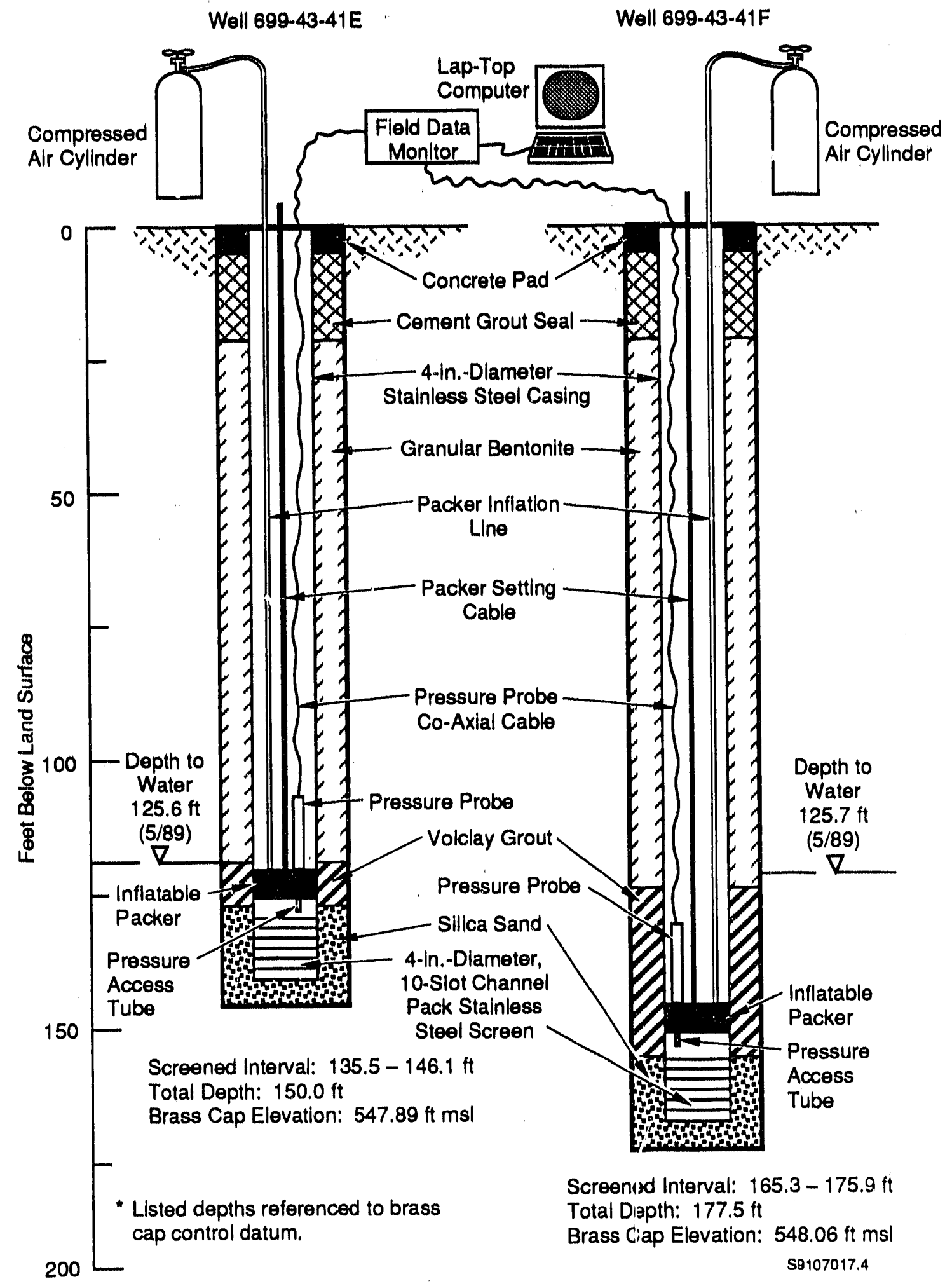

FIGURE 4.2. Construction As-Builts and Test Equipment Installations for Observation Wel1s 699-43-41E and 699-43-41F 
Well 699-43-41G

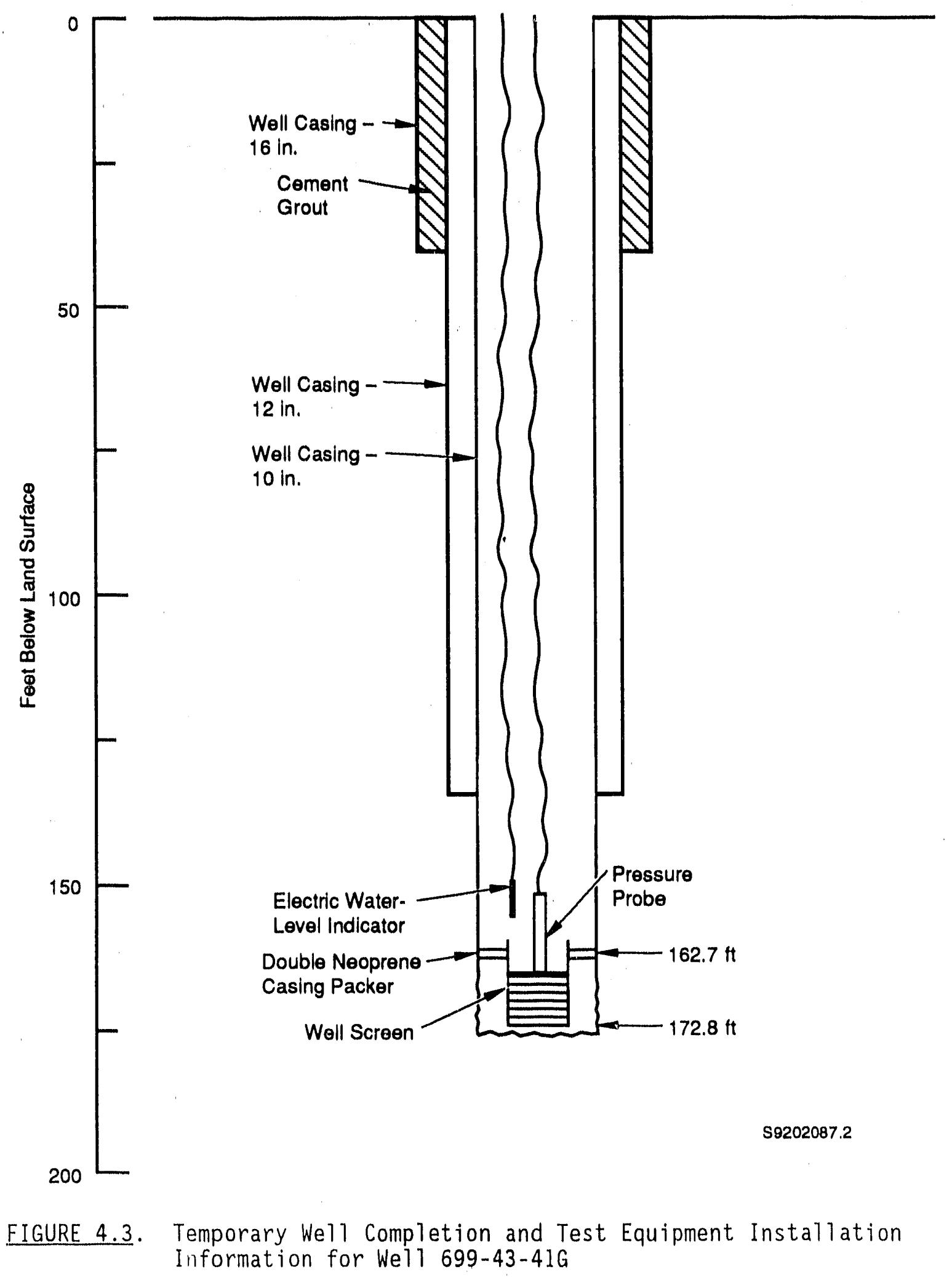

4.5 
The Seling Corporation single pressure probe was used to sense pressure conditions below the set packer by means of a packer access-through tube that was connected to the pressure probe sensor port. Pressure readings of the pressure probe were transmitted to a surface field data monitor (Seling model \# FDM 8500), using the 1/4-in.-0.D., co-axial conductor cable. Pressure readings were printed directly using the field data monitor. Originally, downhole pressures were also planned to be stored directly on a personal computer for later data retrieval and analysis. However, a lack of required compatible electronic components eliminated the possibility of direct data storage to the personal computer.

\section{Stress Well}

Upon reaching the targeted geologic horizon at well 699-43-41G, a temporary well screen assembly was installed. The well screen assembly consisted of $\approx 20$-ft section of 8 -in.-diameter stainless steel well screen, $\approx 5$ - ft blank section of stainless steel well casing, and a dual neoprene packer mounted on the top, blank section (see Figure 4.3). The dual neoprene packer served to block the direct incursion of sand and sediment during testing, i.e., from outside the we11 screen into the inside of the 10-in.-diameter well casing.

As in the observation wells, a Seling Corporation single pressure probe ( 0 to $200 \mathrm{psia}$, Paroscientific Inc. quartz transducer) was also used to measure fluid pressure responses in the stress we11. The pressure probe was located immediately above the well-screened section to ensure that the probe remained submerged during all phases of slug testing. Pressure probe measurements were transmitted using the 1/4-in.-0.D., co-axial conductor cable to the same Seling Corporation field data monitor and personal computer system used to record the observation well pressure measurements.

An electric water-level indicator was also installed immediately above the well-screened section to detect when fluid levels within the stress well were depressed (i.e., by using compressed nitrogen gas) to this leve1. The electric water-level indicator used was of a type commonly utilized on the Hanford Site to support hydraulic characterization investigations (e.g, In-Situ Corporation, etc.). 
The electric water-level indicator and pressure probe co-axtal cables were conducted through an air-tight, surface wellhead assembly as shown in Figure 4.4. General components of the wellhead assembly include:

- a welded connection, attaching the wellhead assembly to the 10-in.diameter well casing,

- four, 4-in.-diameter nipples and quick-release ball valves mounted on the side of the wellhead,

- a welded slip-on flange that provides an air-tight seal for passing cables and lines through the top of the wellhead assembly, and

- a pressure regulator and air-hose connection for administering nitrogen from a compressed nitrogen cylinder to the inside of the we11 casing.

\subsection{TEST DESCRIPTION}

The original test design called for slug interference tests to be conducted in two separate test zones in we11 699-43-41G. The two test zones corresponded approximately with the screened sections monitored at the adjacent observation wells. The test zones were to be tested sequentially, after reaching the desired depths during drilling. Both observation wells are screened in a sand and gravel unit that is located immediately below a silt and clay zone that occurs within the middle Ringold Formation. As indicated in Table 4.1, well 699-43-41E is screened in the upper sand and gravel (135 to $146 \mathrm{ft}$ ), while well 699-43-41F is located in the lower (165 to $176 \mathrm{ft}$ ) sand and gravel section. Projected test depth-intervals at the test stress well 699-43-41G were expected to correspond to these screened depths. The horizontal (surface) distances between zones for the tests, based on well coordinate survey information, are provided in Table 4.2. As indicated, the horizontal distances between the wells are approximately $50 \mathrm{ft}$.

Although the original test plan called for two zones to be tested at well 699-43-41G, upon reaching the shallowest proposed test interval (i.e., approximately 135 to $145 \mathrm{ft}$, corresponding to the monitored interval at we11 699-43-41E), adverse hydrogeologic conditions for conducting a slug interference test were encountered. These adverse conditions included a greater percentage of fine-grained sediments in the proposed test interval, a 


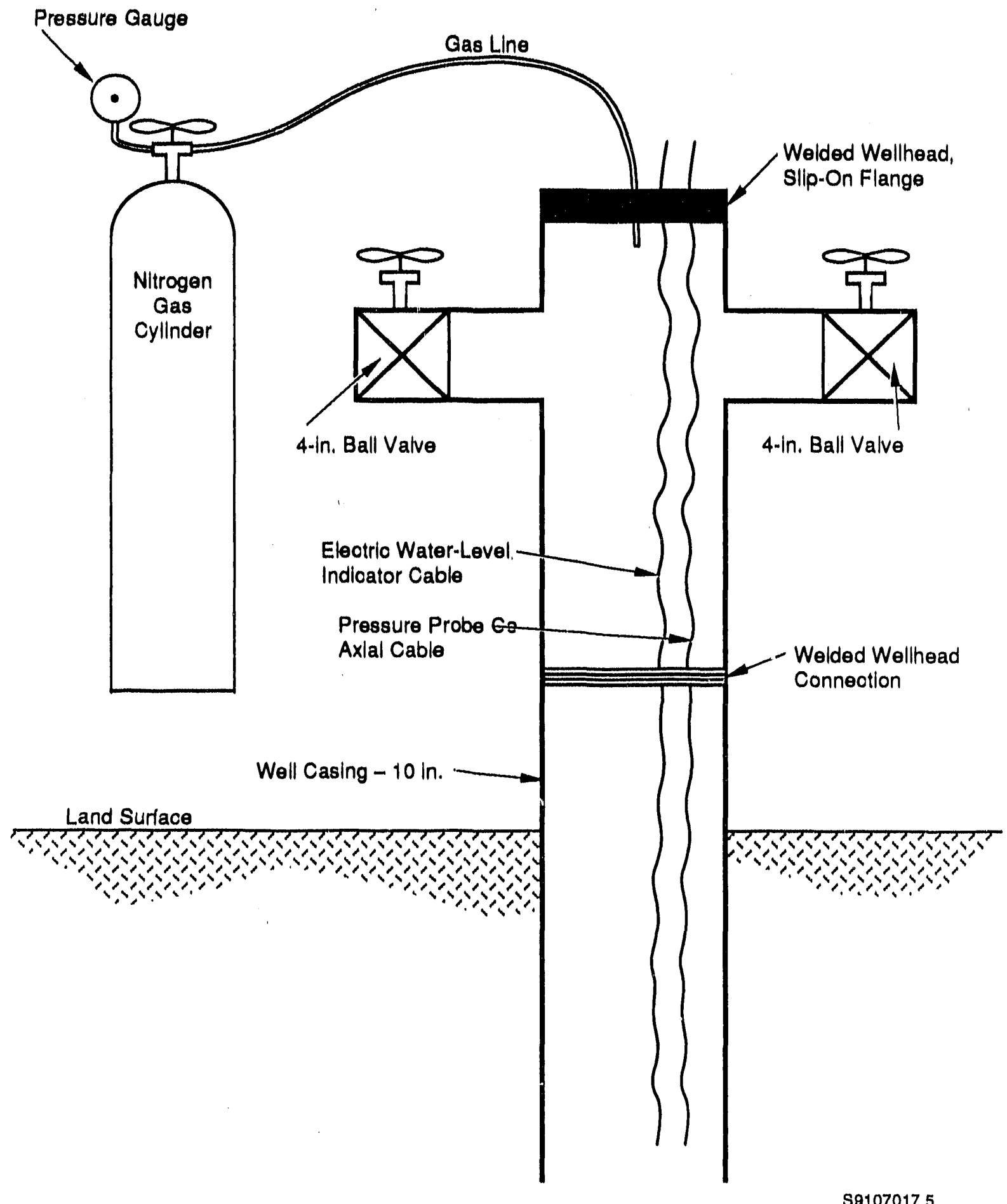

FIGURE 4.4. General Wellhead Assembiy Components for Well 699-43-41G 
thinner zone of saturation, and significantly lower transmisstutty conditions (assumed on the basis of the large percentage of fine-gratned sediments present) within the proposed test interyal. Because of these encountered conditions, slug interference testing was not attempted for the shallowest proposed interval, and drt11ing proceeded to the second proposed test depth interval (f.e., approximately 163 to $173 \mathrm{ft}$ ).

The second proposed test interval was encountered on August 26, 1991. Drfiling continued to a temporary completion depth of $173 \mathrm{ft}$ on August 26, 1991. Following the cessation of drilling activities, test interval development by stressing and removing water from the well by repeatedly balling the wel1 was completed between 1030 and 1100 hours (approximately 160 to 200 gallons removed), and 1300 and 1330 hours (approximately 80 to 100 gallons removed) on August 26th. A temporary well screen assembly (as descrtbed in Section 4.2 and Figure 4.3) was installed in well 699-43-41G between 0900 and 1125 hours on August 27 th. Following the installation the well screen/test interval was developed by batling approximately 180 gallons.

To provide a preliminary indication of in situ hydraulic conditions, a low stress (approximately $2.4 \mathrm{ft}$ stress displacement) slug injection and withdrawal test were conducted using a slugging rod beginning at 1317 hours, on August 27th. Results from this preliminary testing are not included in this report. Qualitative analysis of these tests, however, provided estimates of transmissivity for the stress well that were consistent with results obtained during slug interference testing (see Section 3.3.2). The well-head assembly was then attached to the $10-\mathrm{in}$. well casing and the pressure probe and electric water-level sensor installed within the well on August 28th.

Depression of the water level within well 699-43-41G using injected compressed nitrogen (following the procedure described in Section 4.3), commenced at 1132 hours on August 28th using a gas injection pressure of $15 \mathrm{lb} / \mathrm{in}^{2}$. This selected injection pressure was designed to depress the water level within the stress well approximately $35 \mathrm{ft}$ below the static level, which prior to gas injection was $126.56 \mathrm{ft}$ below land surface. A constant gas pressure of about $15 \mathrm{lb} / \mathrm{in}^{2}$ was maintained inside the well casing to equilibrate the we11/ test interval system during the gas injection test phase. The electric 
water-level sensor was also monttored during this pertod to ensure that gas was not infected into the screened interval. The infection of displaced water tinto the test interval resulted in detectable pressure chariges at both observation wells. Pressures at both observation wells were allowed to equilibrate before beginning the slug withdrawal test.

The slug interference test was inttiated at 0809:30 hours on August 29th, when the gas pressure within the well casing was abruptly released. The gas pressure was released in about 1 s by simultaneously opening the four, 4$i n$. ball valves on the surface well-head assembly. The release of gas caused ground water within the test interval to flow back inside the well casing, thus creating a slug withdrawal at the stress we 11. Pressure measurements were recorded at the stress we11, and the slug interference response monttored at the two observation wells (i.e., 699-43-41E and 699-43-41F). Discernable interference responses to the slug test were observed at both observation wells. Analysis of the slug interference responses recorded at the two observation wells, as well as the slug response at the stress well, are presented in the following section.

\subsection{IEST ANALYSIS}

\subsubsection{Barometric Effects}

Because of the anticipated small slug interference response, $p l a n s$ were initiated to remove the effects of barometric pressure fluctuations from the observed slug interference record. The relationship between barometric pressure change and associated test interval pressure response has been previously described by a number of investigators for confined (e.g., Jacob 1940) and unconfined aquifers (e.g., Weeks 1979). To determine the relationship between barometric and aquifer pressure changes (t.e., barometric efficiency), pretest interval pressures were monitored at each observation well beginning on August 5th. However, because of power supply and data acquisition system constraints, data records were discontinuous and of short-length during the pre-test period. Figure 4.5 shows test interval pressure responses for observation wel1s 699-43-41E and 699-43-41F, in comparison to hourly atmospheric pressure readings recorded at the Hanford meteorological station (located 

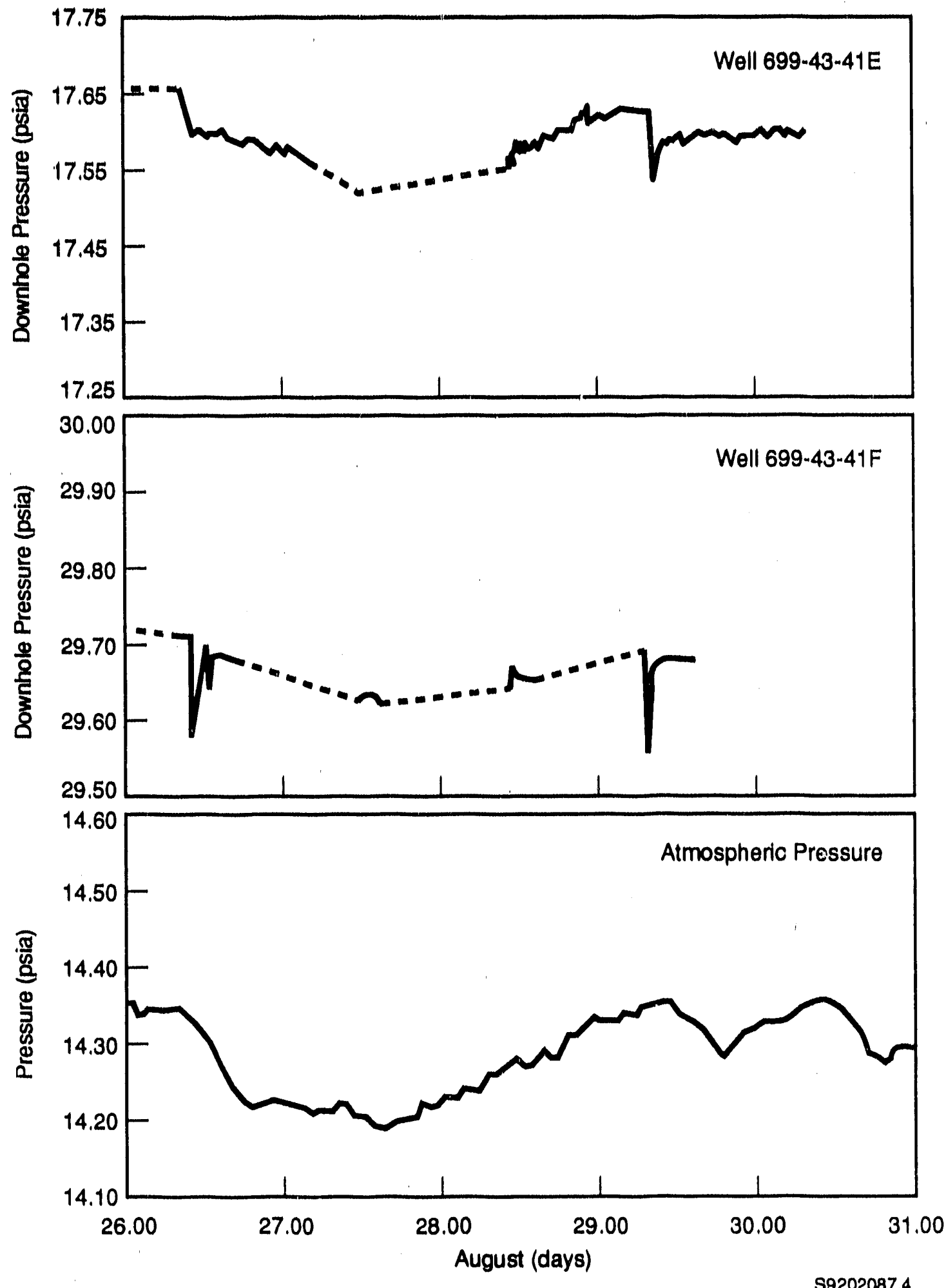

FIGURE 4.5. Comparison of Downhole Pressure Measurements for Wells 699-43-41E and 699-43-41F and Atmospheric Pressure Readings Observed During the Period August 26 to 30,1991 
approximately 5 miles from the test factitty), between August 26 and 30 . As indicated in Figure 4.5, considerable correspondence between test interval pressure and atmospheric pressure trend fluctuations is indicated.

To remove the effects of barometric fluctuations from the observed siug interference response recorded at 'wells 699-43-41E and 699-43-41F, the barometric efficiency for the test interval must be determined. The barometric effictency of an open we11/aquifer system was first defined by Jacob (1940), and can be expressed as:

$$
B E=-\tau_{f o}\left(\Delta h_{s} / \Delta P_{0}\right)
$$

where $\tau_{\mathrm{fc}}=$ average specific weight of the fluid column in the well; $\left(1 \mathrm{~b} / \mathrm{ft}^{3}\right)$

$\Delta h_{s}=$ change in elevation of the fluid column in the well associated with atmospheric pressure change; (ft)

$\Delta P_{0}=$ change in atmospheric pressure; $\left(1 \mathrm{~b} / \mathrm{ft}^{2}\right)$

Downhole pressure measured within an open well or in the aquifer $\left(P_{f}\right)$, however, responds directly with atmospheric pressure fluctuations, but at a magnitude equal to the atmospheric pressure change minus the pressure change because of the change in the fluid column elevation within the well (Spane and Mercer 1985):

$$
\Delta P_{f}=\Delta \bar{P}_{o}-\tau_{f c} \Delta h_{s}
$$

or simplifying,

$$
\Delta P_{f}=(1-B E) \Delta P_{0}
$$

Equations 10 and 11 indicate that the change in downhole formation pressure represents only that portion of the atmospheric pressure change not borne by the test formation matrix. Therefore, high barometric efficiencies are 
reflective of high strength and rigid test formations, while low efficiencies indicate formations that are highly compressible (Spane and Mercer 1985).

The barometric efficiency for observation wells 699-43-41E and 699-43-41F was calculated utilizing the procedure described in Clark (1967). The Clark method is particularly applicable in calculating barumetric efficiencies from test interval responses that are influenced by the presence of other extraneous trerids. Briefly stated, the method requires determining the barometric efficiency from the slope of a summation plot of the incremental changes in downhole formation pressure, $\Sigma \Delta P_{f}$ versus the incremental change in atmospheric pressure, $\Sigma \Delta P_{0}$. Incremental changes in downhole formation pressure are added to the summation total when the incremental sign change is equal to that of the incremental atmospheric pressure, $\Delta P_{0}$ sign change for the observed incremental period (e.g., when $\Delta P_{f}$ and $\Delta P_{o}$ are both positive or negative). Conversely, incremental changes in downhole formation pressure are subtracted from the summation total when the incremental sign change is unequal to that of the incremental atmospheric pressure sign change for the observed period. In addition, no incremental change in downhole formation pressure is added to the summation total when no change in atmospheric pressure is recorded.

Figure 4.6 shows the combined plot of summation totals for incremental downhole formation pressure versus incremental atmospheric pressure changes as calculated using the Clark method for wells 699-43-41E and 699-43-41F for discontinuous data collected during the pre-test period (i.e., August 5 to August 28). Because of data acquisition system limitations, only a few data points are available for analysis during the pre-test period for well 699-43-41F. As shown, however, the data for well 699-43-41F plot closely to the trend exhibited for well 699-43-41E. Based on this combined analysis, a barometric efficiency of 0.382 (i.e., 38.2\%) is indicated. The barometric efficiency value determined was utilized in removing the effects of barometric pressure change from the slug interference test response recorded at observation wells 699-43-41E and 699-43-41F. Results of the slug interference test analysis for the individual observation wells are presented in the following respective report sections. 


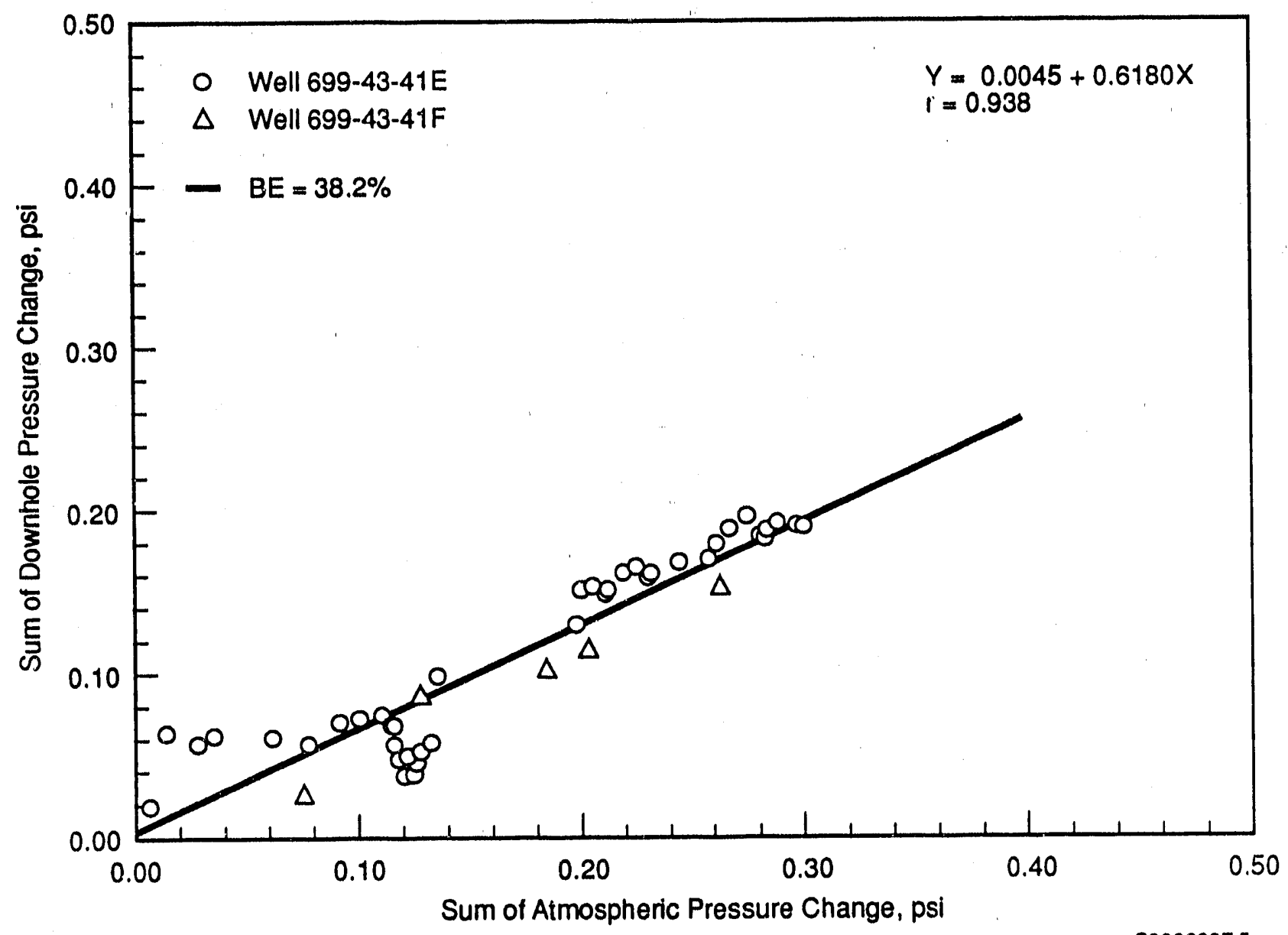

$\$ 9202087.5$

FIGURE 4.6. Barometric Efficiency Calculation for Observation Wells 699-43-41E and 699-43-4IF

\subsubsection{Stress Wel1 699-43-41G Response}

The initiation of the slug interference test by the abrupt release of compressed gas within the well casing at well 699-43-41G (at 0809:30 hours on August 29th) caused ground water to flow back inside the well casing from the surrounding test interval, thus creating a slug withdrawal at the stress well. The fluid column had been depressed with compressed gas resulting in an induced stress level, $H_{0}$, of $15.151 \mathrm{~b} / \mathrm{in}^{2}$ below the observed, pre-test downhole pressure value of $32.02 \mathrm{lb} / \mathrm{in}^{2}$. The resulting pressure recovery was analyzed utilizing the technique described in Ostrowski and Kloska (1989), which employs the simultaneous type-curve matching of the dimensionsless 
pressure (i.e., $\mathrm{H} / \mathrm{H}_{\mathrm{O}}$ ) versus time and the derivative of dimensionsless pressure versus time. The technique is superior to the procedure described in Cooper et a1. (1967) for dimensionless pressure versus time in that the ambiguity in type-curve selection is significantly reduced.

Figure 4.7 shows the type-curve analysis of the slug withdrawal test response at the stress well using the Ostrowski and Kloska (1989) analysis procedure. As indicated, a transmissivity of approximately $60 \mathrm{ft}^{2} / \mathrm{d}$ was calculated for the screened interval section using a type-curve match of alpha $=10^{-6}$. Like the Cooper et a1. (1967) analysis method, the Ostrowski and

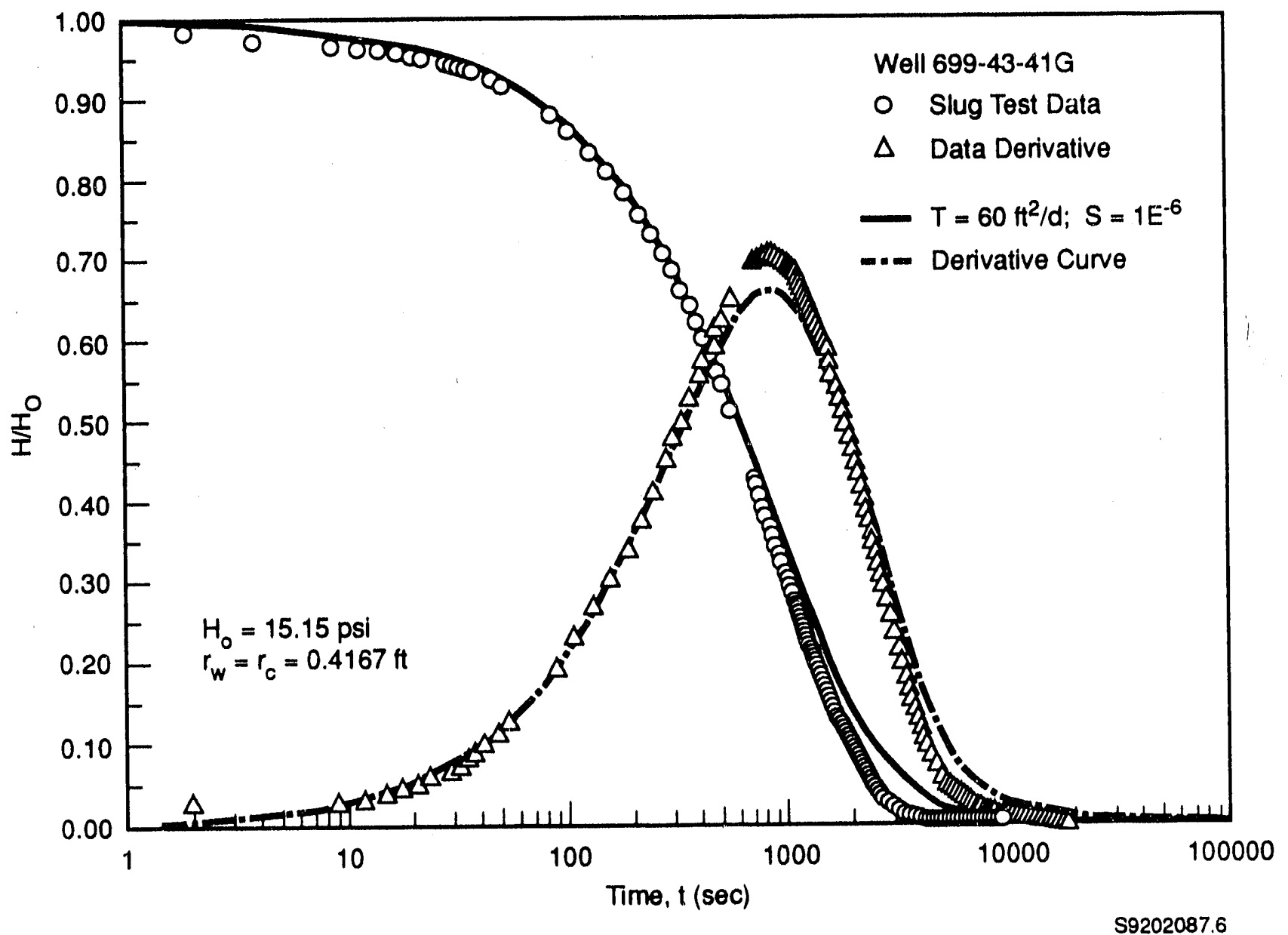

FIGURE 4.7. Slug Test Analysis for Stress Well 699-43-41G Using the Ostrowski and Kloska (1989) Analysis Method 
Kloska (1989) technique is strictly valid only for fully penetrating wells. However, as indicated by Cooper et a1. (1967) few wells completely penetrate an aquifer, and for wells partially penetrating stratified aquifers (where vertical hydraulic conductivities are commonly less than horizontal hydraulic conductivities) it can be assumed that two dimensional flow conditions exist during the test. For these situations, " ... the determined value of transmissivity $(T)$ would represent approximately the transmissivity of the part of that part of the aquifer in which the well is screened..." (Cooper et a1., 1967). Based on a well screen length of $10.6 \mathrm{ft}$, an equivalent hydraulic conductivity for the test section of $5.7 \mathrm{ft} / \mathrm{d}$ is indicated.

Additional examination of Figure 4.7 indicates a departure of the slug test data (i.e., after $600 \mathrm{~s}$ ) from that predicted by the type curve. This can be indicative of non-radial flow conditions induced by vertical flow components or leaky aquifer behavior within the zone of influence for the test. Slug test head data and its derivative versus time (as shown in Figure 4.7), however, cannot be used diagnostically to identify the presence of non-radial flow behavior. This is in contrast to constant-rate pumping tests, which have been shown to display specific pressure derivative patterns for various ground-water flow conditions (e.g., Bourdet et al. 1983; Ehlig-Economides 1988).

Figure 4.8 shows the pattern of dimensionless pressure, $P_{D}$, and the dimensionless pressure derivative, $P_{D}{ }^{\prime}$, during a constant-rate test for a stress well with no storage (Theis type curve) and for various wellbore storage conditions. As indicated in the figure, wellbore storage produces a characteristic "hump" pattern in the pressure derivative plot, which increases in amplitude and duration as the associated dimensionless wellbore storage value, $C_{D}$, increases. Radial flow conditions are indicated when the pressure derivative becomes horizontal (i.e., when $P_{D}^{\prime}=0.5$ ). For the examples shown, radial flow conditions are established for test times with $T_{D} / C_{D}$ values greater than about 1000 .

The presence of non-radial flow conditions caused by vertical flow or leaky aquifer behavior, is denoted on a pressure derivative plot by a diagnostic response pattern that significantly deviates below the horizontal 


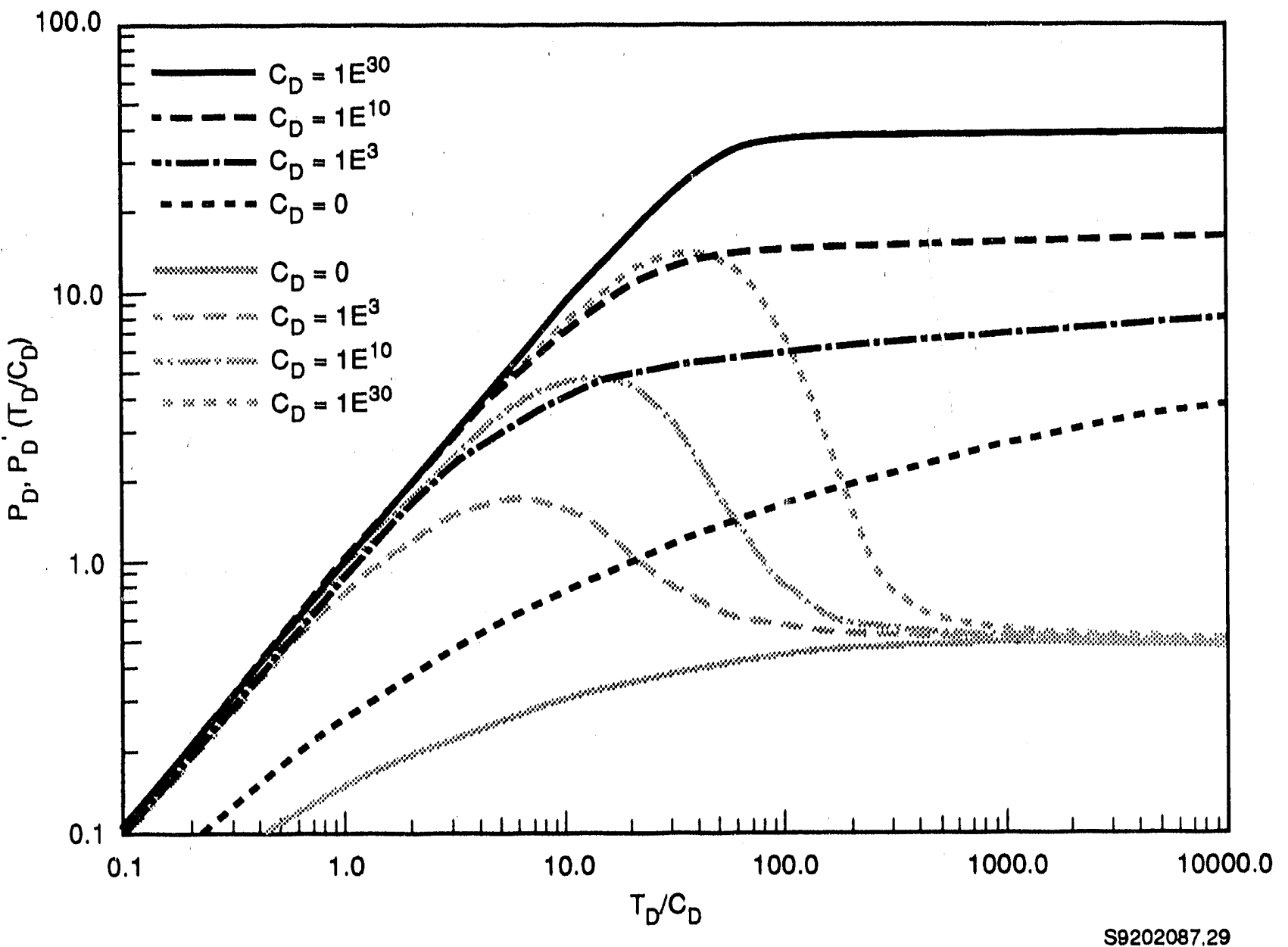

FIGURE 4.8. Dimensionsless Pressure and Dimensionless Pressure Derivative Type Curves for Constant-Rate Pumping Tests. (After Bourdet et al. 1983).

radial flow-line region of the graph (i.e., $P_{D}^{\prime}=0.5$ ). In comparison, vertical flow or leaky aquifer behavior is less obvious on a simple dimensionless pressure change plot, with its presence only suggested by a subtle deviation below the pressure change plot.

To verify the presence of non-radial flow conditions, leakage, boundaries, etc., slug test data must be first converted to an equivalent head response that would be obtained during a constant-rate pumping test, and then converted to equivalent head derivatives. Conversion of slug test response 
data to equivalent head and head derivative values associated with a constantrate test can be accomplished following the transformation procedure described in Peres et a1. (1989). The presence of non-rad:al flow conditions attributable to vertical flow or leaky aquifer behavior can then be diagnostically assessed using pressure 'derivative analysis plots of the form shown in Figure 4.8 .

Figure 4.9 shows the results of transforming slug test data collected at well 699-43-41G to its equivalent head and derivative form for a constant-rate

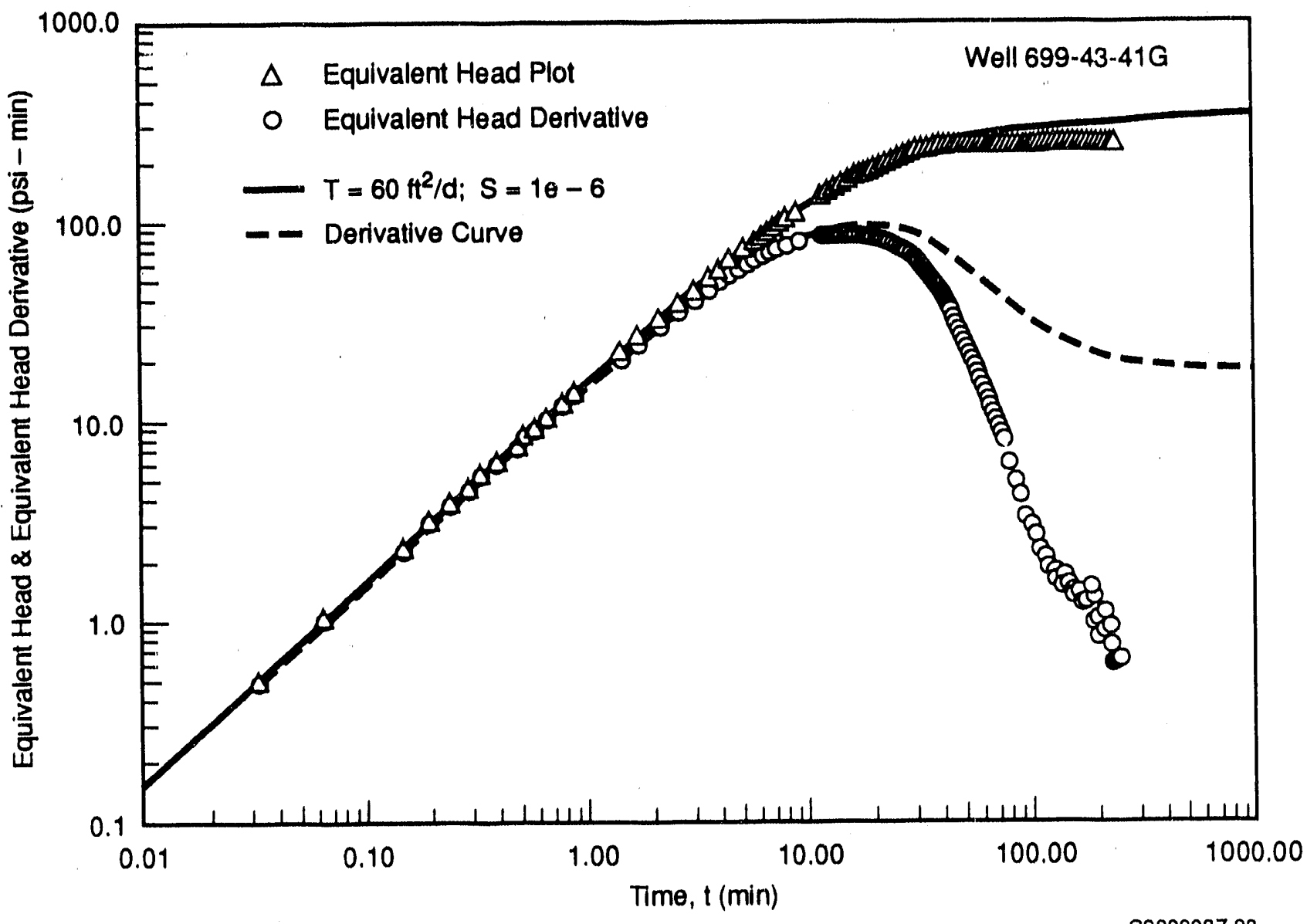

FIGURE 4.9. Diagnostic Analysis of Equivalent Head and Equivalent Head Derivative Plot Data for Slug Test Conducted at We11 $699-43-41 G$ 
test. Also shown is the predicted equivalent head and head derivative typecurve response based on the previously obtained siug test analysis results for transmissivity (i.e., $T=60 \mathrm{ft}^{2} / \mathrm{d}$ ) and storativity $\left(S=10^{-6}\right.$ ) as indicated in Figure 4.7. The equivalent head type-curve response was calculated using the modified version of the Novakowski (1990) program, while the equivalent head derivative was determined based on the derivative algorithm described in Bourdet et a1. (1989). As indicated in the figure, the equivalent head derivative response significantly deviates below the predicted derivative response after a test time of approximately 10 minutes. The deviation below the derivative type-curve region indicated for wellbore storage and radial flow confirms the presence of non-radial flow conditions that are characteristic of vertical flow/leakage behavior. Also shown in the figure is the fact that these non-radial flow conditions are only exhibited by a subtle departure from the predicted equivalent head change type curve; thereby, demonstrating the utility of pressure-derivative analysis.

The diagnostic analysis and type-curve matching results suggest that the transmissivity value of $60 \mathrm{ft}^{2} / \mathrm{d}$ obtained for the slug test analysis based on the Ostrowski and Kloska (1989) method (Figure 4.7) is probably a reasonable estimate of hydraulic properties for the interval tested, since it is based on type-curve matching of test data prior to establishment of significant vertical flow or leaky aquifer flow conditions (i.e., prior to test times of 10 minutes). This estimate, however, is expected to be slightly greater than actual conditions, due to the likelihood of some vertical flow or leaky aquifer behavior even during the early stages of the test.

For test analysis comparison, slug test data were also analyzed utilizing the procedure described in Bouwer and Rice (1976) and Bouwer (1989). This analysis procedure (which is based on the Thiem equation) was developed for unconfined aquifer conditions and accounts for the effects of partial penetration at the stress we11. For this analysis procedure, equivalent hydraulic conductivity for the interval tested is equal to:

$$
K=\frac{r c^{2} \ln (R e / r w) \ln \left(y_{0} / y t\right)}{2 L_{e} t}
$$


where $r_{c}=$ radius of the well casing; $(\mathrm{ft})$

$r_{w}=$ radius of the well; $(\mathrm{ft})$

$R_{e}=$ effective test radius; ( $\left.f t\right)$

$y_{0}=$ pressure difference from static pressure at time $t_{0} ;\left(1 \mathrm{~b} / \mathrm{in^{2 }}\right)$

$y_{t}=$ pressure difference from static pressure at time $t_{t} ;\left(1 \mathrm{~b} / \mathrm{in^{2 }}\right)$

$L_{e}=$ screened test interval length; $(\mathrm{ft})$

$t=$ test time at $y_{t} ;(\mathrm{sec})$

where:

$$
\begin{aligned}
& \text { for } L_{w}=H \\
& \ln R_{e} / r_{w}=\left[\left(1.1 / \ln \left(L_{w} / r_{w}\right)\right)+C /\left(\ln \left(L_{e} / r_{w\}}\right)\right]^{-1}\right. \\
& \text { for } L_{w}<H \\
& \ln R_{e} / r_{w}=\left[\left(1.1 / \ln \left(L_{w} / r_{w}\right)\right)+\left(A+B \ln \left\{\left(H-L_{w}\right) / r_{w}\right\} /\left(\ln \left(L_{e} / r_{w}\right)\right]^{-1}\right.\right.
\end{aligned}
$$

where $H=$ aquifer thickness; $(\mathrm{ft})$

$L_{w}=$ distance from the water table to the bottom of the test section; $(\mathrm{ft})$

This analysis method is commonly used for slug tests conducted in the unconfined aquifer on the Hanford Site. Bouwer and Rice (1976) indicate that their analysis method should provide estimates of transmissivity that are of the "same order" as those calculated with the procedure of Cooper et al. (1967). Figure 4.10 shows the analysis results for the slug withdrawal test based on the Bouwer and Rice (1976) method. As indicated, a lower hydraulic conductivity value of $2.3 \mathrm{ft} / \mathrm{d}$ was obtained, which was based on the following input parameters: $H=52 \mathrm{ft}$ (static water level to top of clay layer at $179 \mathrm{ft}$ ); $r_{c}$ $=0.4167 \mathrm{ft} ; \ln \left(R_{\mathrm{e}} / r_{w}\right)=2.72$ (calculated from Equation 4 and Figure 2 in Bouwer (1989) for $\left.L_{e} / r_{w}=24.24\right) ; y_{0}=15.2 \mathrm{lb} / \mathrm{in}^{2} ; y_{t}=.053 \mathrm{lb} / \mathrm{in}^{2}(\mathrm{Fig}-$ ure 4.10); $L_{e}=10.1 \mathrm{ft}$; and, $t=5,000 \mathrm{~s}$ (Figure 4.10). 


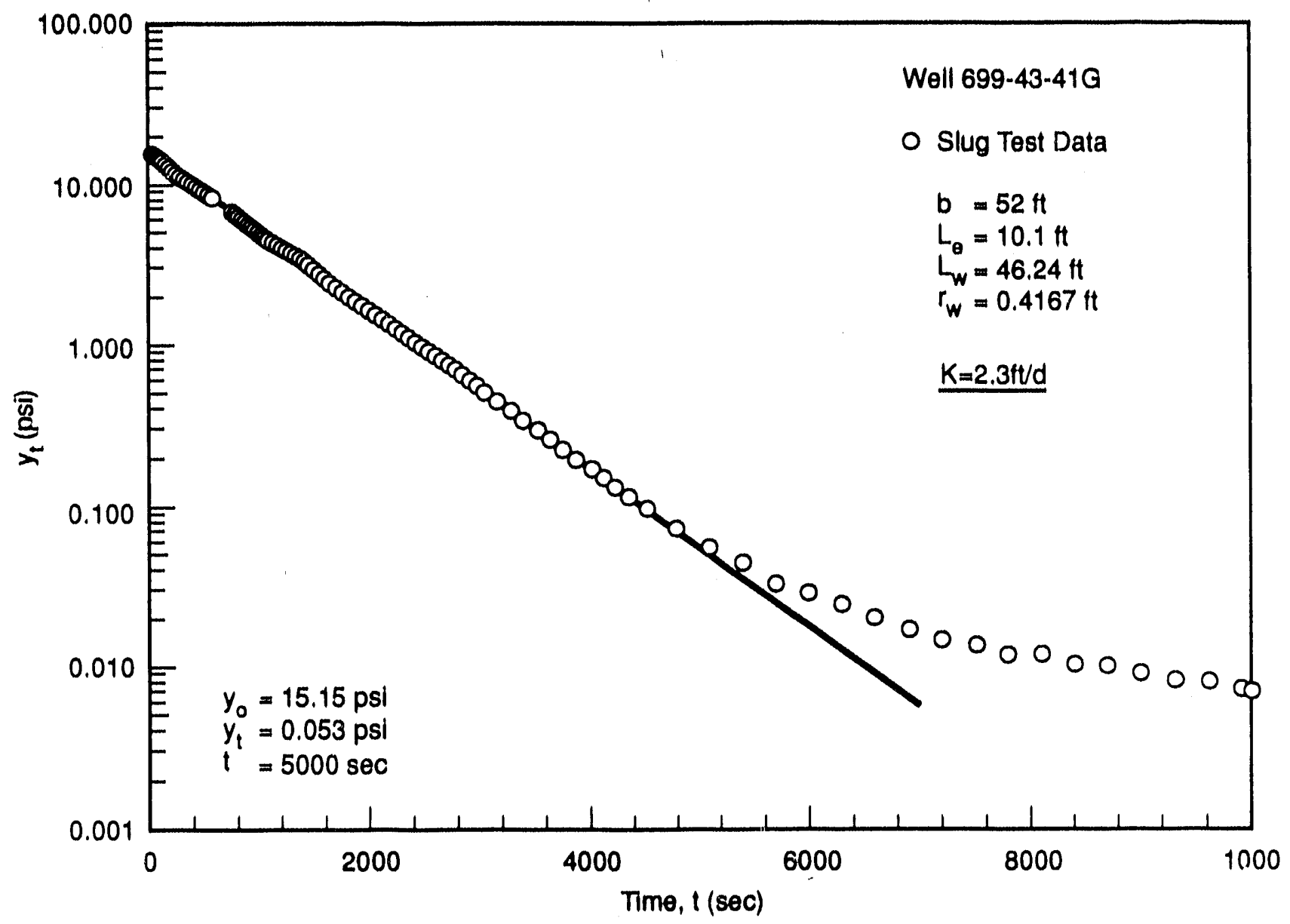

S9202087.7

FIGURE 4.10. Slug Test Analysis for Stress We11 699-43-41G Using the Bouwer and Rice (1976) Analysis Method

The Bouwer and Rice (1976) method is based on the Thiem steady-state solution, which does not account for aquifer elastic storage during testing. In addition, the dimensionless parameters $A, B$, and $C$ that are used in the analysis procedure [(Equations (13) and (14)] are based on empirical relationships developed from electric analog studies that relate effective test radius, $R_{e}$, with various test geometries. Because of the empirical nature of the developed relationships, Bouwer and Rice (1976) cite a relative accuracy for their technique of between $10 \%$ to $25 \%$. 
Because of various limitations that were brlefly descrlbed for both slug test analysis methods (1.e., Ostrowski and Kloska 1989; Bouwer and Rice 1976), no preferred or "best-estimate" of equivalent hydraulic conductivity is assigned for this test. The transmissivity estimates obtained for each analysis method are provided as a range for comparison with slug interference test results. As a consequence, an assigned equivalent hydraulic conductivity range between $2.3 \mathrm{ft} / \mathrm{d}$ and $5.7 \mathrm{ft} / \mathrm{d}$ is provided from analysis of the slug withdrawal test conducted at well 699-43-41G.

\subsubsection{Observation We11 699-43-41E Response}

The slug withdrawal test at well 699-43-41G caused a maximum slug interference pressure response of $0.093 \mathrm{lb} / \mathrm{in}^{2}$ at observation wel1 699-43-41E. The maximum response was recorded approximately 1,800 seconds after slug initiation. Figure 4.11 shows the slug interference response, both for corrected and uncorrected for barometric pressure changes during the test. As indicated, considerable improvement in the late-time data profile was obtained by removing the effects of atmospheric pressure fluctuation. Examination of Figure 4.11 indicates that the slug pressure "hump" or "wave" was first detected at approximately $300 \mathrm{~s}$, with residual effects of the slug interference still manifested in the observation well response up to 20,000 s.

Figure 4.12 shows the slug interference test analysis for barometric corrected data collected at observation well 699-43-41E. Type curves shown were generated using a modified version of the Novakowski code described in Section 3.0 and an observation well distance of $48 \mathrm{ft}$ (horizontal distance separating the stress and observation wells). For comparison purposes, the sensitivity of the analysis to different values of storativity and transmissivity are shown in Figures $4.12 \mathrm{a}$ and $4.12 \mathrm{~b}$, respectively. As indicated, the best fit for the observed slug interference response at observation we11 699-43-41E is obtained using a transmissivity value of $145 \mathrm{ft}^{2} / \mathrm{d}$ and a storativity value of $4.4 \times 10^{-3}$. The transmissivity and storativity values obtained from the analysis are mainly reflective of aquifer conditions from the stress well to the point of observation. Based on an aquifer thickness of $52 \mathrm{ft}$, an equivalent hydraulic conductivity value of $2.8 \mathrm{ft} / \mathrm{d}$ is iridicated for 


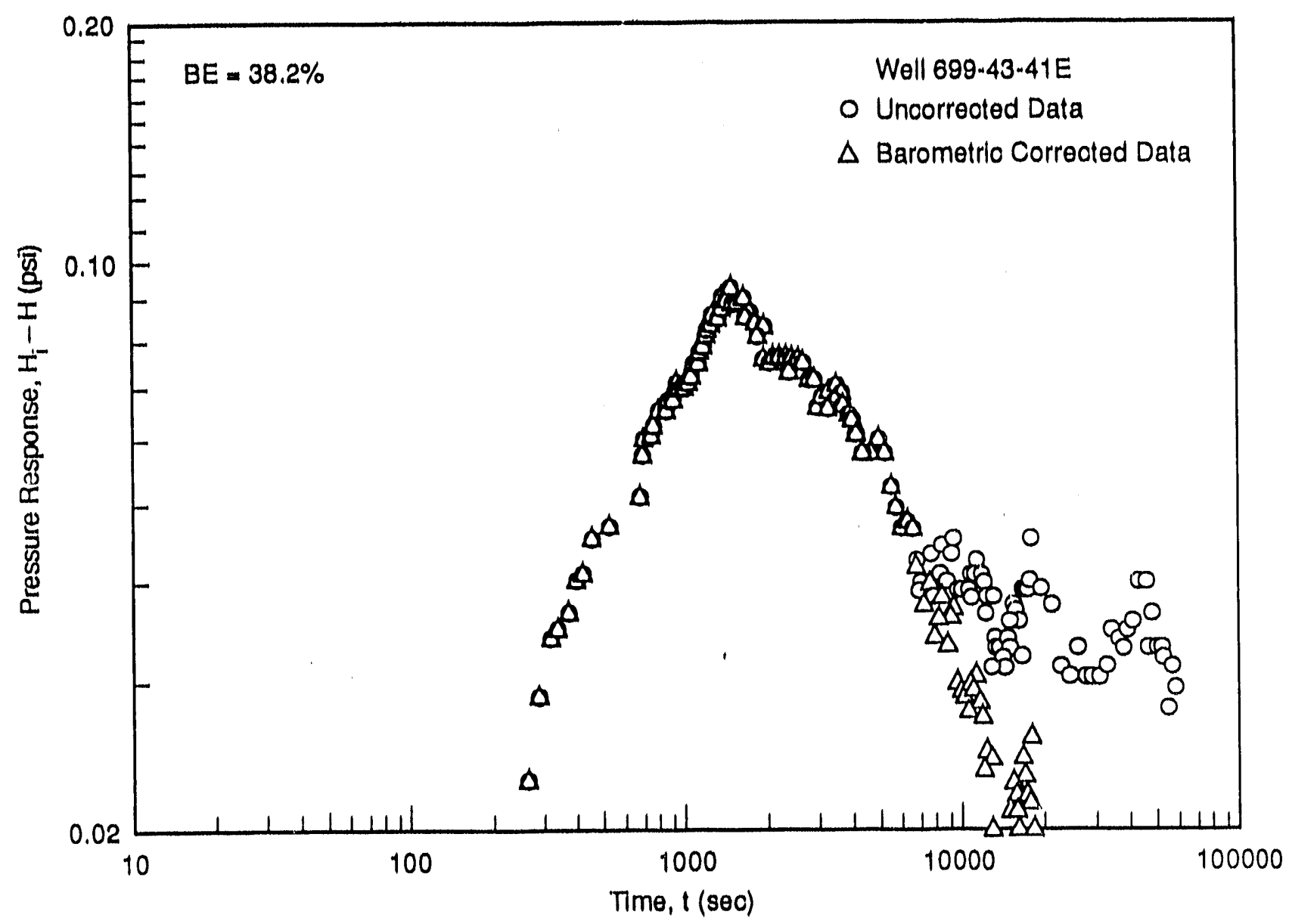

59202087.8

FIGURE 4,11. Slug Interference Response Data Recorded at Observation Well 699-43-41E

the intervening geologic matertals. This estimate value falls within the lower range obtained at we11 699-43-41G for the lower aquifer section tested, which is based on single-well slug test analysis.

Analysis of the slug interference response observed at we11 699-43-41E, using the computer program presented in Novakowski (1990), assumes that the slug peak or central slug interference "hump" (which is the focus of analysis procedure) is not significantiy affected by deiayed-yteld (1.e., vertical flow/leakage) test behavior (see Section 3.2.1). The presence of delayedyteld behavior can be discerned by converting the observed slug test data to 


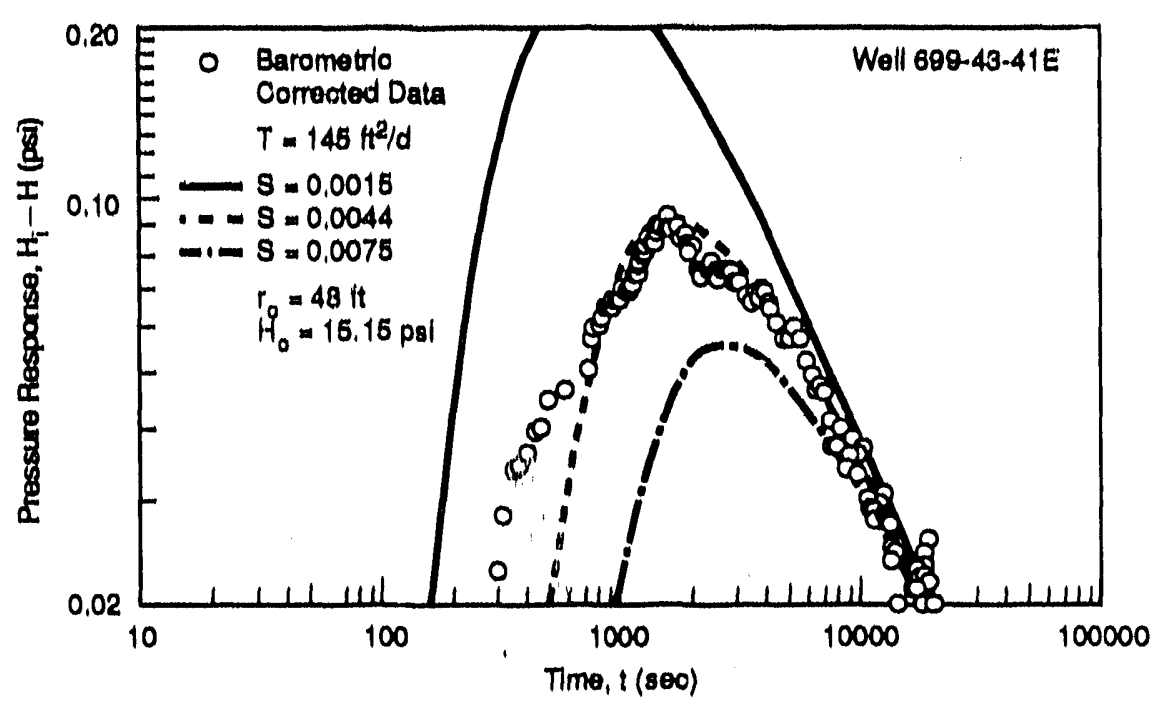

(a)

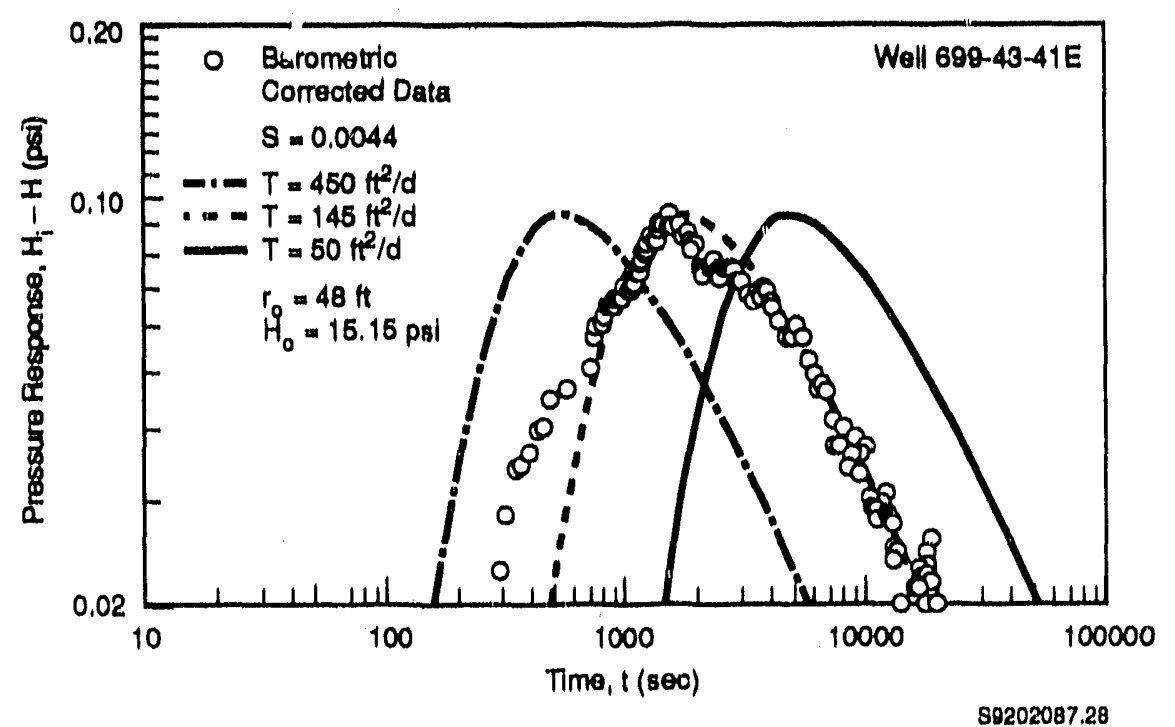

(b)

EIGURE 4.12. Slug Interference Test Analys is for Well 699-43-41E Showing: a) Effect of Varying Storativity, and b) Effect of Varying Transmissivity 
equivalent head and equivalent head derivative values for a constant-rate pumping test. Conversion of slug test response data for well 699-43-41E. to equivalent head and head derivative values rollowed the procedure described in Section 4.4.2 for analyzing test results obtained at we11 699-43-41G. The presence of delayed-yteld behavtor was then assessed using pressure dertvative analysis of the equivalent head response as also described in Section 4.4.2.

Figure 4.13 shows the results of transforming slug test data collected at well 699-43-41E to its equivalent head and derivative form for a constantrate test. Also shown is the predicted equivalent head and head derfvative type-curve response based on the previously obtatned slug interference test analysis results for transmissivity (1.e., $T=145 \mathrm{ft}^{2} / \mathrm{d}$ ) and storativity ( $\mathrm{S}=$ $4.4 \times 10^{-3}$ ) as indicated in Figure 4.12 . The equivalent head type-curve

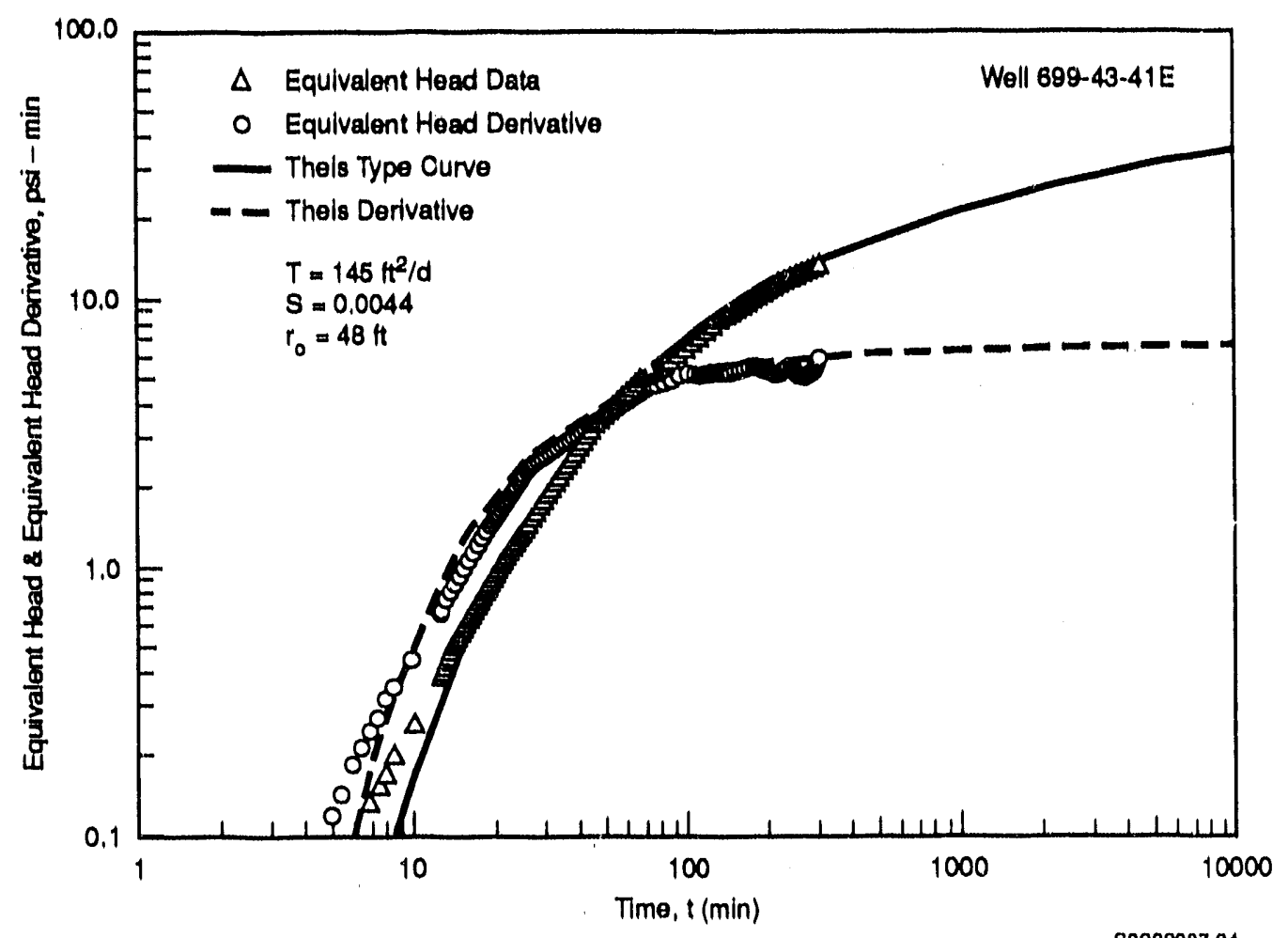

FIGURE 4.13. Diagnostic Analysis of Equivalent Head and Equivalent Head Derivative Plot Data for Slug Interference Test Observed at We11 699-43-41E 
response was calculated using the modifled version of the Novakowski (1990) program, while the equivalent head derivative was determined based on the dertvative algorithm described in Bourdet et a1. (1989). As indicated in the figure, the equivalent head and head derivative response closely match the response predicted by the type curve. Diagnostic analysis of the derivative response pattern indicates that no significant delayed-yield effects were evident in the observed test data. This suggests that the transmissivity of $145 \mathrm{ft}^{2} / \mathrm{d}$ and storativity of $4.4 \times 10^{-3}$ obtained from the siug interference analysis are reasonable estimate of hydraulic properties for the intervening aquifer materials.

\subsubsection{Observation Well 699-43-41F Response}

The slug withdrawal test at well 699-43-41G caused a maximum slug interference pressure response of $0.14 \mathrm{lb} / \mathrm{in}^{2}$ at observation wel1 699-43-41F. The maximum response was recorded approximately $650 \mathrm{~s}$ after slug initiation. Figure 4.14 shows the slug interference response, both corrected and uncorrected for barometric pressure changes during the test. In contrast to data obtained for observation we11 699-43-41E, 1ittle improvement is indicated in the data profile obtained by removing the effects of atmospheric pressure fluctuation. This is due to the fact that the observed slug interference response dissipated more rapidiy, prior to the occurrence of significant atmospheric pressure fluctuations that were manifested later in the test. Examination of Figure 4.14 also indicates that the slug pressure "hump" or "wave" was first detected at approximately $75 \mathrm{~s}$, with residual effects of the slug interference still evident in the observation well response up to 4,000 s. This represents an earlier detection and slug interference dissipation by a factor of 4 to 5 in comparison to that recorded at observation well 699-43-41E.

Figure 4.15 shows the slug interference test analysis for data collected at observation well 699-43-41F. As in the analysis previously described for observation we11 699-43-41E, the type curves shown were generated using a modified version of the Novakowskt code described in Section 3.0 and an observation well distance of $49 \mathrm{ft}$ (horizontal distance between the stress we 11 and the point of observation. For comparison purposes, the sensitivity 


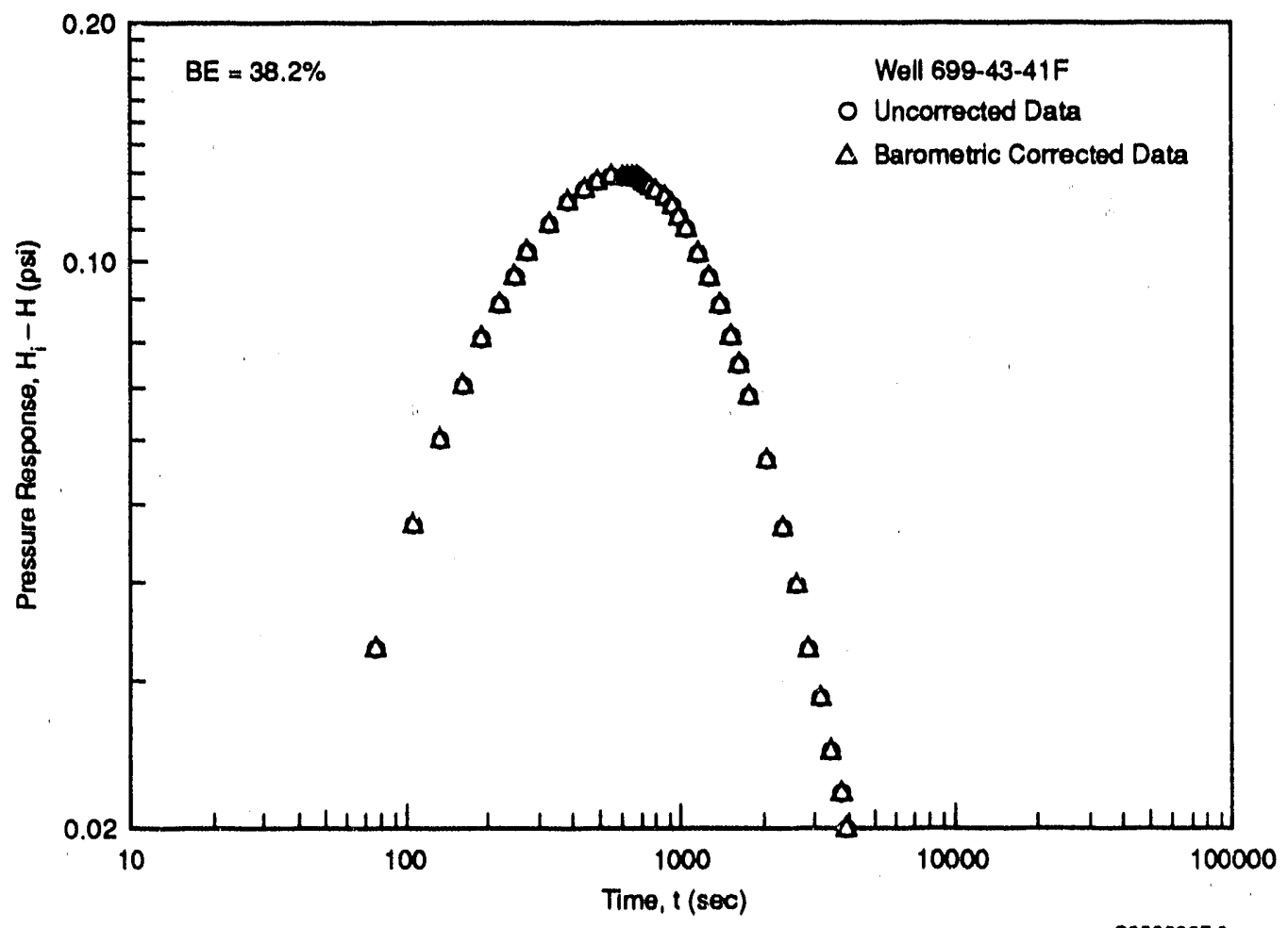

FIGURE 4.14. Slug Interference Response Data Recorded at Observation Wel1 699-43-41F

of the analysis to different values of storativity and transmissivity are shown in Figures $4.15 \mathrm{a}$ and $4.15 \mathrm{~b}$, respectively. As indicated, the best fit for the observed slug interference response at observation we11 699-43-41F is obtained using a transmissivity value of $310 \mathrm{ft}^{2} / \mathrm{d}$ and a storativity value of $2.9 \times 10^{-3}$. The transmissivity value is approximately a factor of two higher than that obtained from analysis of test data for observation we11 699-43-41F. The storativity value is nearly the same as that calculated for observation well 699-43-41E and suggests semi-confined conditions, but is also within the elastic response range commonly exhibited by unconfined aquifers (e.g., Gambolati 1976; Neuman 1974, 1979). The transmissivity and storativity values obtained from the analysis are mainly reflective of aquifer conditions from the stress well to the point of observation. Based on an aquifer thickness of $52 \mathrm{ft}$, an equivalent hydraulic conductivity value of $6.0 \mathrm{ft} / \mathrm{d}$ is indicated 

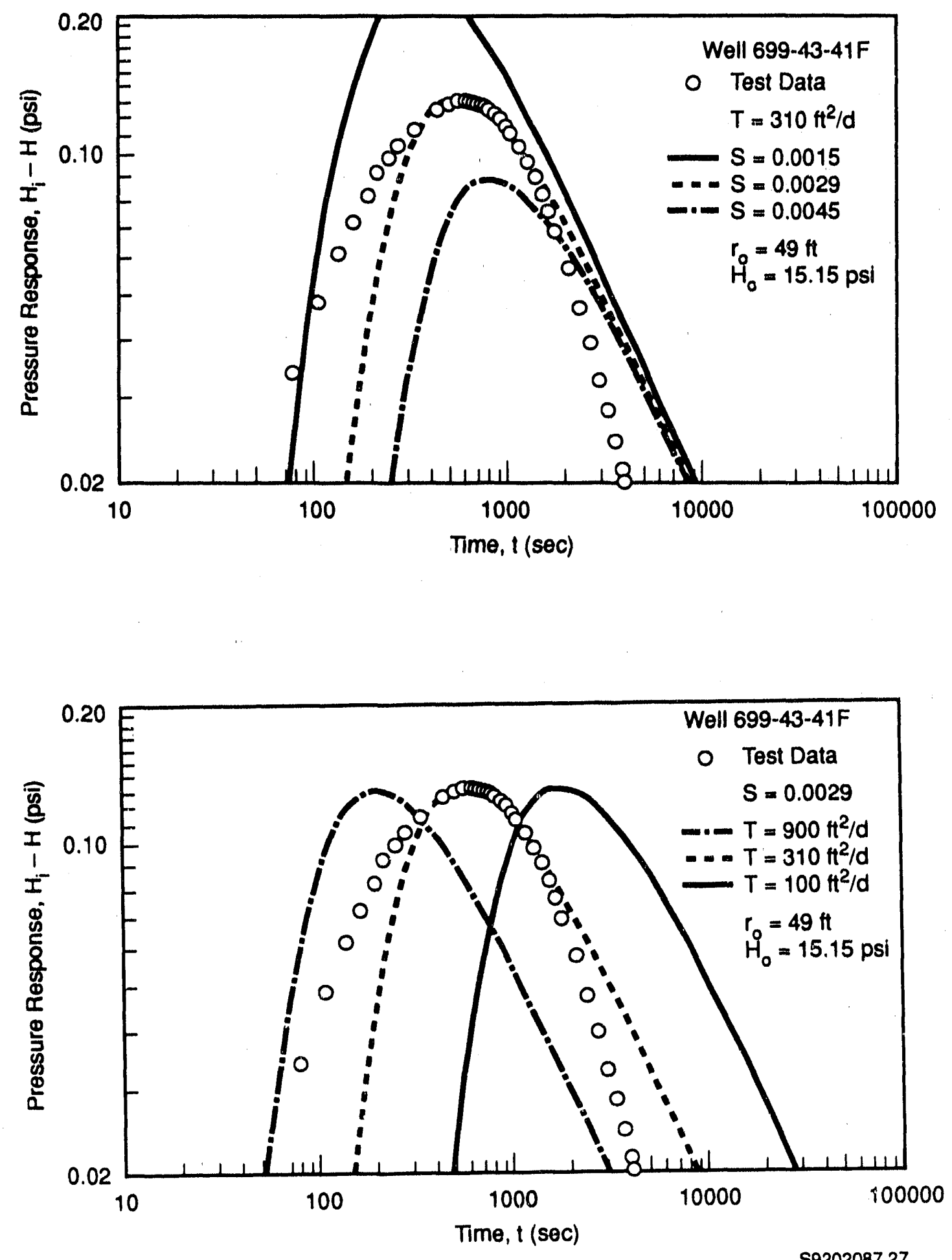

EIGURE 4.15. Slug Interference Test Analys is for Well 699-43-41F 
for the intervening geologic materials. This estimate falls near the upper range obtained at wel1 699-43-41G (for the lower aquifer test section), which is based on single-well slug test analysis.

It should be noted that while an appropriate fit of the central data region was obtained, early-time (buildup) and late-time data (recovery) do not precisely match the type-curve. Possible explanations for this behavior include the presence of relatively significant vertical ground-water flow/ leakage conditions during testing, partial penetration effects, etc.

Analysis of the slug interference response observed at wel1 699-43-41F, using the computer program presented in Novakowski (1990), assumes that the slug peak or central slug interference "hump" (which is the focus of analysis procedure) is not significantly affected by delayed-yield (i.e., vertical flow/leakage) test behavior (see Section 3.2.1). The presence of delayedyield behavior can be discerned by converting the observed slug test data to equivalent head and equivalent head derivative values for a constant-rate pumping test. Conversion of slug test response data for well 699-43-41F to equivalent head and head derivative values followed the procedure described in Section 4.4.3 for analyzing test results obtained at we 11 699-43-4lE. The presence of delayed-yield behavior was then assessed using pressure derivative analysis of the equivalent head response as described in Section 4.4.2.

Figure 4.16 shows the results of transforming slug test data collected at well 699-43-41F to its equivalent head and derivative form for a constantrate test. Also shown is the predicted equivalent head and head derivative type-curve response based on the previously obtained slug interference test analysis results for transmissivity (i.e., $T=310 \mathrm{ft}^{2} / \mathrm{d}$ ) and storativity ( $\mathrm{S}=$ $2.9 \times 10^{-3}$ ) as indicated in Figure 27 . The equivalent head type-curve response was calculated using the modified version of the Novakowski (1990) program, while the equivalent head derivative was determined based on the derivative algorithm described in Bourdet et al. (1989). As indicated in the figure, the equivalent head derivative response significantly deviates below the predicted derivative response after a test time of approximately 30 minutes. The deviation below the derivative of the Theis type-curve confirms the presence of non-radial flow conditions that are characteristic of 


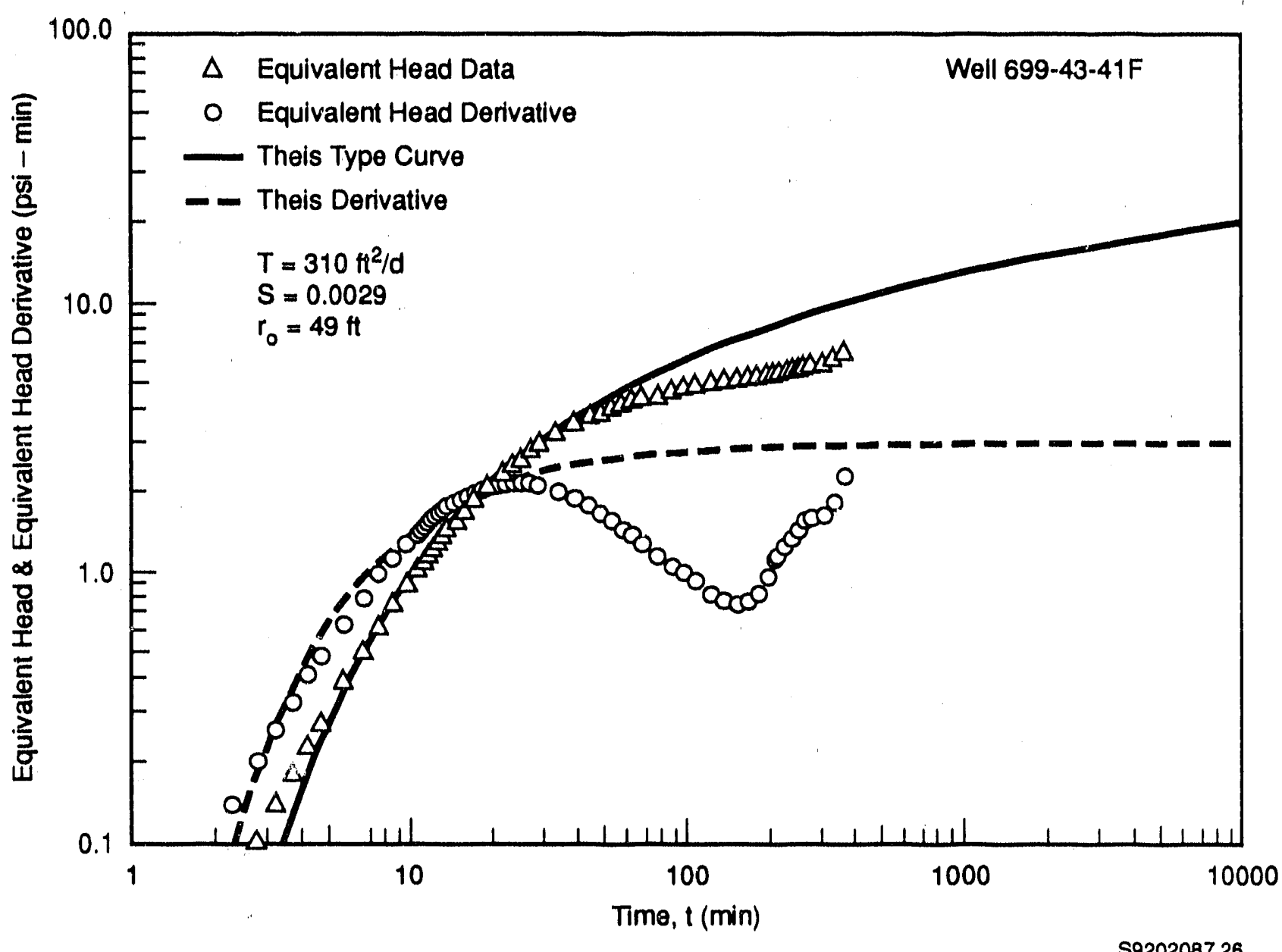

FIGURE 4.16. Diagnostic Analysis of Equivalent Head and Equivalent Head Derivative Plot Data for Slug Interference Test Observed at Well 699-43-41F

delayed yield (i.e., vertical flow/leakage) behavior. The leakage or delayed yield conditions are also evident in the figure by the deviation below the The is equivalent head type curve.

The late-time (i.e., $t>200 \mathrm{~min}$ ) upward deflection of the equivalent head derivative data, back to the indicated radial flow conditions on the Theis derivative plot is interesting. The return to radial flow conditions in late-time may be related to the third-segment of unconfined aquifer response behavior which follows delayed-yield response (see Section 3.2.1). In this 
region, time-drawdown data follows that predicted by the Theis equation with storativity equal to its combined elastic storage component, $S_{e}$, and specific yield, $S_{y}$. Not enough data is present, however, to corroborate this observation.

The diagnostic anaiysis and type-curve matching results suggest that the values for transmissivity of $310 \mathrm{ft}^{2} / \mathrm{d}$ and storativity of $2.9 \times 10^{-3}$ obtained for the slug interference test analysis are reasonable estimates of hydraulic properties for the intervening aquifer materials; since it is based on typecurve matching of test data prior to establishment of significant vertical flow or leaky aquifer flow conditions (i.e., prior to test times of $30 \mathrm{~min}$ utes). This estimate, however, would be expected to be slightly greater than actual conditions, due to the likelihood of some vertical flow or leaky aquifer behavior even during the early stages of the test. 


\subsection{CONCLUSIONS}

Results of the field test evaluation indicate that analyzable slug interference responses were obtained at two nearby observation wells (699-43-41E and -43-41F) located approximately 48 and $49 \mathrm{ft}$, respectively, from the stress test well (699-43-41G) location. Slug interference analysis provided transmissivity estimates for the unconfined aquifer between the stress well and observation well location of $145 \mathrm{ft}^{2} / \mathrm{d}$ and $310 \mathrm{ft}^{2} / \mathrm{d}$. Based on an aquifer thickness of $52 \mathrm{ft}$, an estimate range for equivalent hydraulic conductivity from $2.8 \mathrm{ft} / \mathrm{d}$ to $6.0 \mathrm{ft} / \mathrm{d}$ is indicated for the intervening aquifer between the stress and observation well locations. This hydraulic conductivity range compares favorably with single-well slug test analysis results obtained at the stress well (i.e., equivalent hydraulic conductivity ranging between $2.3 \mathrm{ft} / \mathrm{d}$ and $5.7 \mathrm{ft} / \mathrm{d}$ ) during interference testing, which was representative of the screened interval test section. Less correspondence is exhibited for previously conducted low-stress, single-well slug tests estimates that were obtained at the observation well locations (i.e., between $0.4 \mathrm{ft} / \mathrm{d}$ and $1.0 \mathrm{ft} / \mathrm{d}$, and between $1.4 \mathrm{ft} / \mathrm{d}$ and $2.8 \mathrm{ft} / \mathrm{d}$ obtained for we $11 \mathrm{~s}$ 699-43-41E and -43-41F, respective1y), which are discussed in Appendix $C$. The reason for the lower correspondence with results obtained from the previously conducted single-well (observation we11) slug tests is not known; however, it may be related to the considerably smaller range of investigation attributed to the low stress level (approximately $1 / 10$ that utilized during the slug interference test), which was imposed at the observation wells during the previously conducted single-well tests.

Storativity estimates obtained from slug interference test analysis for the observation wells provided similar results ranging between $2.9 \times 10^{-3}$ and $4.4 \times 10^{-3}$. These estimated storativity values suggest semi-confined conditions, but are also within the elastic response range commonly exhibited by unconfined aquifers (e.g., Gambolati 1976; Neuman 1974, 1979).

Other salient conclusions that are pertinent for slug interference test analysis are provided below:

5.1 
1. For observation wells displaying a long-duration and low amplitude response, the recorded slug interference data can be significantly improved for type-curve analysis by removing the effects of other extraneous stress factors, such as barometric fluctuations during testing.

2. The central slug interference test data "hump" should be the focus for analysis using the program presented in Novakowski (1990). The analysis method assumes that no vertical/leakage flow conditions are significant within this focusing region of the slug test data set.

3. The presence of non-radial flow conditions (i.e., vertical/leakage flow) within regions of the data set, which are not valid using Theis equation based solutions, can be detected through use of diagnostic pressure derivative analysis. The procedure requires that the slug test data be first converted to equivalent head and head derivative data that would be obtained during a constant-rate pumping test, following the procedure described in Peres et al. (1989). The equivalent head and head derivative data can then be subjected to diagnostic analysis using available dimensionless pressure and dimensionless pressure derivative type curves (e.g., Bourdet et al. 1983, 1989).

4. Because of the favorable observation well distance versus aquifer thickness ratio ( $i . e ., r / b \approx 1$ ), no corrections for stress well partial penetration effects were applied to the observed slug interference data. It should be possible, however, to correct for partial penetration effects by following the methods presented in Weeks (1969), which would be applied to the slug test data that has been transformed to equivalent head form.

Initial results of the analytical assessment and field evaluation for applying slug interference testing as a possible hydraulic characterization method at the Hanford Site are encouraging. It would appear to be particularly attractive for providing hydraulic characterization in contaminated areas where the use of standard hydrologic characterization methods (e.g., pumping tests) may not be possible (i.e., due to disposal problems created by the production of contaminated ground water).

While the slug interference test field evaluation provided representative results for a test formation (Ringold Formation) possessing an intermediate transmissivity (i.e., $10^{2} \mathrm{ft}^{2} / \mathrm{d}$ ), the real benefit of the technique at 
the Hanford Site may be for characterizing higher transmissivity formations (> $10^{3} \mathrm{fta}^{2} / \mathrm{d}, \mathrm{e} . \mathrm{g}$. , overlying glaciofluvial deposits) for which single-well slug test methods are not applicable.

Additional field evaluation tests are recommended to more, fully assess the applicablitty range of slug interference testing. In particular, it is recommended that a site is selected that has already undergone detalled hydraulic characterization using standard hydraulic characterization techniques (i.e., constant-rate pumping tests). It would also be useful if additional sites be tested with test intervals that encompass the water table; since this condition is expected to attenuate and delay the slug interference signal produced at the stress well. 


\subsection{REFERENCES}

Bourdet, D., J. A. Ayoub, and Y. M. Pirard. 1989. Use of Pressure Derivative In Well-Test Interpretation, Society of Petroleum Engineers, SPE Formation Evaluation, June 1989, pp. 293-302.

Bourdet, D., T. M. Whittle, A. A. Douglas, and Y. M. Pirard. 1983. "A New Set of Type Curves Simplifies Well Test Analysis." World 011, May 1983, pp. 95-106.

Bouwer, H. 1989. "The Bouwer and Rice Slug Test -- An Update." Ground Water $27(3): 304-309$.

Bouwer, H., and R. C. Rice. 1976. "A Slug Test for Determining Hydraulic Conductivity of Unconfined Aquifers With Completely or Partially Penetrating We11s." Water Resources Research 12(3):423-428.

Clark, W. E. 1967. "Computing the Barometric Efficiency of a We11." Proceedings of the American Society of Civil Engineers, Journal of the Hydraulics Division 43(HY4):93-98.

Cooper, H. H., Bredehoeft, J. D., and I. S. Papadopulos. 1967. "Response of a Finite-Diameter Well to an Instantaneous Charge of Water." Water Resources Research 3(1):263-269.

DOE. 1988. Site Characterization Plan. DOE/RW-0164, U.S. Department of Energy, Washington, D.C.

Eh7ig-Economides, C. 1988. "Use of the Pressure Derivative for Diagnosing Pressure-Transient Behavior." Journal of Petroleum Technology, October 1988, pp. $1280-1282$.

Gambolati, G. 1976. "Transient Free Surface Flow to a We11: An Analysis of Theoretical Solutions." Water Resources Research 12(1):27-39.

Gephart, R. E., R. C. Arnett, R. G. Baca, L. S. Leonhart, and F. A. Spane, Jr. 1979. Hydrologic Studies Within the Columbia Plateau, Washington: An Integration of Current Knowledge. RHO-BWI-ST-5, Rockwel1 Hanford Operations, Richland, Washington.

Hantush, M. S. 1961. "Aquifer Tests on Partially Penetrating Wells." Journal of the Hydraulics Division, Proceedings of the American Society of Civil Engineers, HY 5, pp. 171-195.

Heath, R. C. 1983. Basic Ground-Water Hydrology, U.S. Geological Survey, Water Sunply Paper 2220. 
Jacob, C. E. 1940. "On the Flow of Water in an Elastic Artestan Aquifer." Am. Geophys, Union Trans. 14:446-460.

Lohman, S. W. 1972. Ground-Water Hydraultes, U.S. Geological Professtonal Paper 708.

Neuman, S.'P. 1972. "Theory of Flow in Unconfined Aquifers Constdering Delayed Response of the Water Table." Water Resources Research 8(4):1031. 1045.

Neuman, S. P. 1974. "Effect of Partial Penetration of Flow in Unconfined Aquifers Considering Delayed Gravity Response." Water Resources Research $10(2): 303-312$.

Neuman, S. P. 1979. "Perspective on "Delayed Yield." Water Resources Research 15(4):899-908.

Novakowski, K. S. 1989. "Analys is of Pulse Interference Tests." Water Resources Research 25(11):2377-2387.

Novakowski, K. S. 1990. "Analys is of Aquifer Tests Conducted in Fractured Rock: A Review of the Physical Background and the Design of a Computer Program for Generating Type Curves." Ground Water 28(1):99-105.

Ostrowski, L. P., and M. B. Kloska. 1989. "Use of Pressure Derivatives in Analysis of Slug Test or DST Flow Period Data." Soclety of Petroleum Engineers, SPE paper 18595. Paper presented at the SPE Production Operations Symposium, Ok1ahoma City, Oklahoma, March 13-14, 1989.

Peres, A. M., M. Onur, and A. C. Reynolds. 1989. "A New Analys ts Procedure for Determining Aquifer Properties From Slug Test Data." Water Resources Research 25(7):1591-1602.

Ramey, H. J., Jr., R. G. Agarwa1, and I. Martin. 1975. "Analys is of 'Slug Test' or DST Flow Period Data." Journal of Canadian Petroleum Technology, July-September, 1975, pp. 37-47.

Spane, F. A., Jr., and R. B. Mercer. 1985. HEADCO: A Program for Converting Observed Water Levels and Pressure Measurements to Formation Pressure and Standard Hydraulic Head. RHO-BW-ST-71P, Rockwell Hanford Operations, Richland, Washington,

Walter, G. R., and G. M. Thompson. 1982. "A Repeated Pulse Technique for Determining the Hydraulic Properties of Tight Formations." Ground Water 20(2): $186-193$.

Walton, W. C. 1960. "Application and Limitation of Methods Used to Analyze Pumping Test Data." Water Well Journal, Feb. - March 1960. 
Weeks, E. P. 1964. Eleld Methods for Determining Vertical Permeablitty and Aquifer Antsotropy, U.S. Geological Survey, Professtonal Paper 501-D, pp. D193-D198.

Weeks, E. P. 1969. "Determining the Ratio of Hortzontal to Vertical Permeabllity by Aquifer-Test Analysis." Water Resources Research 5(1):196-214.

Weeks, E. P. 1979. "Barometric Fluctuations in Wells Tapping Deep Unconfined Aquifers." Water Resources Research 15(5):1167-1176. 
APPENDIX A

COMPARISON OF NOVAKOWSKI PROGRAM-GENERATED SLUG TEST RESPONSES, WITH PUBLISHED TYPE CURVE RESPONSES AT THE STRESS WELL (COOPER ET AL. 1967) AND OBSERVATION WELL (RAMEY ET AL. 1975) 
COMPARISON OF NOVAKOWSKI PROGRAM-GENERATED SLUG TEST RESPONSES, WITH PUBLISHED TYPE CURVE RESPONSES AT THE STRESS WELL (COOPER ET AL. 1967) AND OBSERVATION WELL (RAMEY ET AL, 1975)

\section{STRESS WELL COMPARISON}

For the test comparison of slug test results at the stress well, the modifled Novakowski (1990) program was run to duplicate results 1 isted in Cooper et a1. (1967) for alpha, $\alpha$, curves: $-1,-3$, and -5 . As indicated from Equation (3), for situations where $r_{c}=r_{w}$, this would be analogous to storativity values of $10^{-1}, 10^{-3}$, and $10^{-5}$.

To use the modified Novakowski program, the selected alpha curve values were converted to dimensionless wellbore storage, $C_{D}$, values using the follawing relationships presented in Novakowski (1990) and Cooper et a1. (1967):

$$
C_{D}=C_{S} /\left(2 \pi r_{w}^{2} S\right)
$$

and,

$$
C_{s}=\pi r_{c}^{2}
$$

and Equation (3),

$$
\alpha=S\left(r_{w}^{2} / r_{0}^{2}\right)
$$

Combining the above listed relationships, yields:

$$
C_{D}=1 / 2 \alpha
$$

The comparison results for the selected alpha curve/dimensionless wellbore storage values, for the given beta (B) values, are presented below. 


\section{Alpha-1}

Beta

0.001

0.01

0.1

1.0

10.0

100.0

0.7460

0.03065

0.002577
Alpha-3

Cooper et Program al. (1967) Results
Alpha-5

Cooper et Program

al. (1967) Results

\subsection{9}

0.9969

0.9854

0.9853

0.9183

0.9257

0.5729

0.04821

0.002653

0.9992

0.9942

0.9991

0.3117

0.9183

0.9572

0.9942

0.5729

0.7080

0.9571

0.03065

0.002577

0.04921

0.08378

0.7079

0.002653

0.002725

0.08372

(Note: Beta, $B=\left(T_{D} / C_{D}\right) / 2$

\section{OBSERVATION WELL COMPARISON}

For the test comparison of predicted slug interference test results at an observation we11, the modified Novakowskt (1990) program was also used to duplicate results 1 isted in Ramey et a1. (1975) for a dimensionless wellbore storage, $C_{D}$, of 1000 and for dimensionless radial distances, $R_{0}$ of 2,20 , and 200 (where $R_{0}=$ radial distance to the point of observation divided by the well bore radius; $\left.r_{0} / r_{w}\right)$.

Dimensionsless Wellbore Storage Constant, $C D,=100$

\begin{tabular}{ll} 
& \multicolumn{2}{c}{ Ramey et } & Program \\
ID/CD a).(1975) & Results \\
\hline
\end{tabular}

\begin{tabular}{ll}
\multicolumn{2}{c}{$\mathrm{RD}=20$} \\
\hline Ramey et & Program \\
a1. (1975) & Results
\end{tabular}

\begin{tabular}{ll}
\multicolumn{4}{c}{$\mathrm{RD}=200$} \\
\hline Ramey et & Program \\
a). (1975) & Results
\end{tabular}

\subsection{0 .592663}

$1.0 \quad 0.518490$

0.592661

0.518490

$5.0 \quad 0.216084$

0.216084

0.000005

0.044472

0.081941

10.000 .099411

0.099412

0.056775

0.011098

0.010990

0.005467

0.005272

${ }^{*}$
0.043852
0.081941
0.056776
0.010990
0.005272
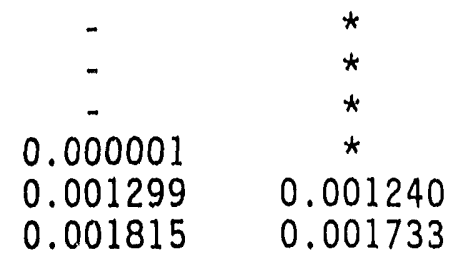

$\begin{array}{rr}50.0 & 0.011098 \\ 100.0 & 0.005466\end{array}$

\begin{tabular}{l}
$\frac{R D}{\text { Ramey et }}$ \\
a1. (1975) \\
\hline 0.000005 \\
0.044472 \\
0.081941 \\
0.056775 \\
0.010990 \\
0.005272
\end{tabular}




\section{Dimensionsless We?lbore Storage Constant, $C D,=1000$}

\begin{tabular}{lll} 
& Ramey et & Program \\
TD/CD & al. (1975) & Results \\
\hline
\end{tabular}

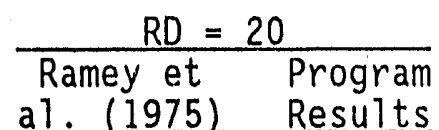

$0.1 \quad 0.736588$

$\begin{array}{ll}1.0 & 0.626510\end{array}$

$5.0 \quad 0.295102$

10.0

50.0

100.0

$\begin{array}{ll}0.730589 & 0.052210 \\ 0.626512 & 0.207075 \\ 0.295102 & 0.155703 \\ 0.139692 & 0.089605 \\ 0.012813 & 0.011998 \\ 0.005627 & 0.005474\end{array}$

0.051593

0.207976

0.155703

0.089605

0.011998

0.005474

\begin{tabular}{cc}
\multicolumn{2}{c}{$\mathrm{RD}=200$} \\
\hline Ramey et & Program \\
a). (1975) & Results \\
\hline
\end{tabular}

* The modified Novakowski program does not calculate dimensionless head responses below 0.00001 .

\section{REFERENCES}

Cooper, H. H., J. D. Bredehoeft, and I. S. Papadopulos. 1967. "Response of a Finite-Diameter We11 to an Instantaneous Charge of Water." Water Resources Research 3(1):263-269.

Novakowski, K. S. 1990. "Analysis of Aquifer Tests Conducted in Fractured Rock: A Review of the Physical Background and the Design of a Computer Program for Generating Type Curves." Ground Water 28(1):99-105.

Ramey, H. J., Jr., R. G. Agarwa1, and I. Martin. 1975. "Analys is of 'Slug Test' or DST Flow Period Data." Journal of Canadian Petroleum Technology, July-September, 1975, pp. 37-47. 
APPENDIX B

\section{SLUG INTERFERENCE TEST DATA}

B.1. Stress Well 699-43-41G

B.2. Observation We11 699-43-41E

B.3. Observation We11 699-43-41F 
TABLE B.1. Slug Interference Test Data - Stress We11 699-43-41G

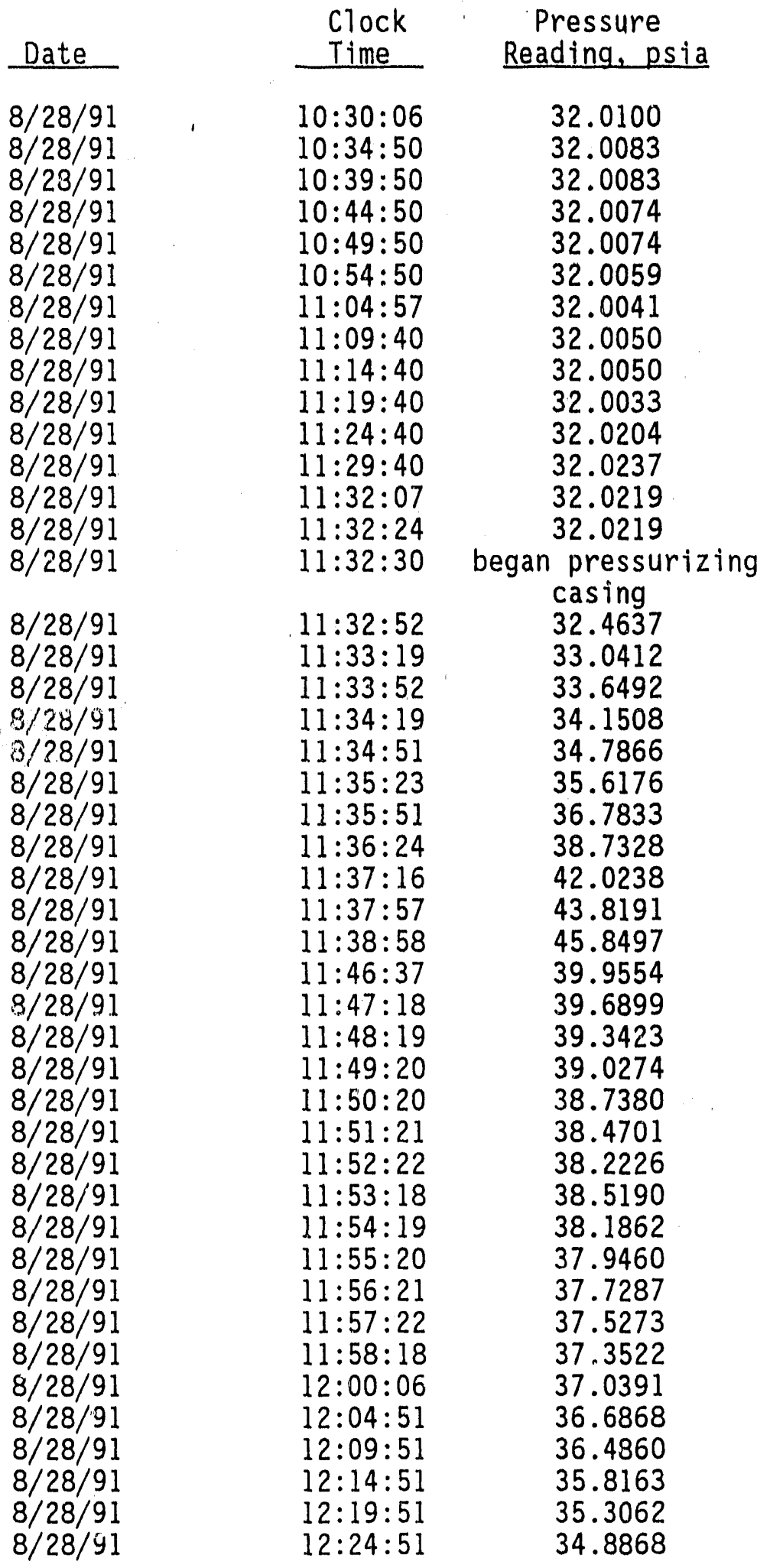

B.1 
TABLE B.1. (contd)

\begin{tabular}{|c|c|c|}
\hline Date & $\begin{array}{l}\text { Clock } \\
\text { Time } \\
\end{array}$ & $\begin{array}{c}\text { Pressure } \\
\text { Reading. psia }\end{array}$ \\
\hline $\begin{array}{l}8 / 28 / 91 \\
8 / 28 / 91 \\
8 / 28 / 91 \\
8 / 28 / 91 \\
8 / 28 / 91 \\
8 / 28 / 91 \\
8 / 28 / 91 \\
8 / 28 / 91 \\
8 / 28 / 91 \\
8 / 28 / 91 \\
8 / 28 / 91 \\
8 / 28 / 91 \\
8 / 28 / 91 \\
8 / 28 / 91 \\
8 / 28 / 91 \\
8 / 28 / 91 \\
8 / 28 / 91 \\
8 / 28 / 91 \\
8 / 28 / 91 \\
8 / 28 / 91 \\
8 / 28 / 91 \\
8 / 28 / 91 \\
8 / 28 / 91 \\
8 / 28 / 91 \\
8 / 28 / 91 \\
8 / 28 / 91 \\
8 / 28 / 91 \\
8 / 28 / 91 \\
8 / 28 / 91 \\
8 / 28 / 91 \\
8 / 28 / 91 \\
8 / 28 / 91 \\
8 / 28 / 91 \\
8 / 28 / 91 \\
8 / 28 / 91 \\
8 / 28 / 91 \\
8 / 28 / 91 \\
8 / 29 / 91 \\
8 / 29 / 91 \\
8 / 29 / 91 \\
8 / 29 / 91 \\
8 / 29 / 91 \\
8 / 29 / 91 \\
8 / 29 / 91 \\
8 / 29 / 91 \\
8 / 29 / 91\end{array}$ & $\begin{array}{l}12: 29: 51 \\
12: 34: 51 \\
12: 39: 51 \\
12: 44: 51 \\
12: 49: 51 \\
12: 54: 51 \\
12: 59: 51 \\
13: 09: 15 \\
13: 18: 59 \\
13: 28: 59 \\
13: 38: 59 \\
13: 48: 59 \\
13: 58: 59 \\
14: 08: 59 \\
14: 18: 59 \\
14: 28: 59 \\
14: 38: 59 \\
14: 48: 59 \\
14: 58: 59 \\
15: 03: 16 \\
15: 32: 59 \\
16: 02: 59 \\
16: 32: 59 \\
17: 02: 59 \\
17: 32: 59 \\
18: 02: 59 \\
18: 32: 59 \\
19: 02: 59 \\
19: 32: 59 \\
20: 02: 59 \\
20: 32: 59 \\
21: 02: 59 \\
21: 32: 59 \\
22: 02: 59 \\
22: 32: 59 \\
23: 02: 59 \\
23: 32: 59 \\
0: 02: 59 \\
0: 32: 59 \\
1: 02: 59 \\
1: 32: 59 \\
2: 02: 59 \\
2: 32: 59 \\
3: 02: 59 \\
3: 32: 59 \\
4: 02: 59\end{array}$ & $\begin{array}{l}34.9676 \\
34.5793 \\
34.2658 \\
34.0073 \\
33.7869 \\
33.6014 \\
33.4398 \\
33.1929 \\
32.9961 \\
32.8403 \\
32.7227 \\
32.6280 \\
32.6818 \\
32.6912 \\
32.6000 \\
32.5310 \\
32.4730 \\
32.4183 \\
32.3699 \\
32.3478 \\
32.2403 \\
32.1652 \\
32.1166 \\
32.0851 \\
32.0697 \\
32.0662 \\
32.0714 \\
32.0842 \\
32.0918 \\
32.0901 \\
32.0927 \\
32.0901 \\
32.0851 \\
32.0766 \\
32.0654 \\
32.0688 \\
32.0740 \\
32.0758 \\
32.0749 \\
32.0732 \\
32.0782 \\
32.0877 \\
32.0851 \\
32.0971 \\
32.0886 \\
32.1047\end{array}$ \\
\hline
\end{tabular}

B. 2 
TABLE B.1. (contd)

$\begin{array}{lcc} & \begin{array}{c}\text { Clock } \\ \text { Date }\end{array} & \begin{array}{c}\text { Pressure } \\ \text { Reading. psia }\end{array} \\ \begin{array}{c}\text { Time } \\ \text { 8/29/91 }\end{array} & 4: 33: 00 & 32.1116 \\ 8 / 28 / 91 & 12: 34: 51 & 34.5793 \\ 8 / 29 / 91 & 7: 02: 59 & 32.0886 \\ 8 / 29 / 91 & 7: 32: 59 & 32.0714 \\ 8 / 29 / 91 & 7: 43: 53 & 32.0654 \\ 8 / 29 / 91 & 7: 48: 37 & 32.0630 \\ 8 / 29 / 91 & 7: 53: 37 & 32.0612 \\ 8 / 29 / 91 & 7: 58: 37 & 32.0586 \\ 8 / 29 / 91 & 8: 03: 37 & 32.0586 \\ 8 / 29 / 91 & 8: 05: 58 & 32.0560 \\ 8 / 29 / 91 & 8: 06: 16 & 32.0569 \\ 8 / 29 / 91 & 8: 06: 43 & 32.0560 \\ 8 / 29 / 91 & 8: 07: 11 & 32.0560 \\ 8 / 29 / 91 & 8: 07: 43 & 32.0560 \\ 8 / 29 / 91 & 8: 08: 11 & 32.0552 \\ 8 / 29 / 91 & 8: 08: 43 & 32.0543 \\ 8 / 29 / 91 & 8: 09: 20 & 32.0534 \\ 8 / 29 / 91 & 8: 09: 27 & 32.0560 \\ 8 / 29 / 91 & 8: 09: 29 & 32.0552 \\ 8 / 29 / 91 & 8: 09: 30 & 31.0567 \\ 8 / 29 / 91 & 8: 09: 31 & \text { released gas pressure } \\ 8 / 29 / 91 & 8: 09: 32 & \text { in stress we11 } \\ 8 / 29 / 91 & 8: 09: 33 & 16.8700 \\ 8 / 29 / 91 & 8: 09: 35 & 17.0190 \\ 8 / 29 / 91 & 8: 09: 40 & 17.1201 \\ 8 / 29 / 91 & 8: 09: 43 & 17.2473 \\ 8 / 29 / 91 & 8: 09: 46 & 17.3031 \\ 8 / 29 / 91 & 8: 09: 49 & 17.3527 \\ 8 / 29 / 91 & 8: 09: 52 & 17.4050 \\ 8 / 29 / 91 & 8: 09: 55 & 17.4590 \\ 8 / 29 / 91 & 8: 10: 01 & 17.5087 \\ 8 / 29 / 91 & 8: 10: 04 & 17.6019 \\ 8 / 29 / 91 & 8: 10: 07 & 17.6515 \\ 8 / 29 / 91 & 8: 10: 10 & 17.7021 \\ 8 / 29 / 91 & 8: 10: 13 & 17.7517 \\ 8 / 29 / 91 & 8: 10: 20 & 17.8014 \\ 8 / 29 / 91 & 8: 10: 26 & 17.9188 \\ 8 / 29 / 91 & 8: 11: 00 & 18.0190 \\ 8 / 29 / 91 & 8: 11: 18 & 18.5871 \\ 8 / 29 / 91 & 8: 11: 45 & 18.8880 \\ 8 / 29 / 91 & 8: 12: 12 & 19.3111 \\ 8 / 29 / 91 & 8: 12: 45 & 19.6803 \\ 8 / 29 / 91 & 8: 13: 17 & 20.1022 \\ 8 / 29 / 91 & 8: 13: 44 & 20.5166 \\ 8 / 29 / 91 & 8: 14: 16 & 20.8662 \\ 8 & & 21.2527 \\ & & \end{array}$

\section{B. 3}


TABLE B.1. (contd)

\begin{tabular}{|c|c|c|}
\hline Date & $\begin{array}{l}\text { Clock } \\
\text { Time } \\
\end{array}$ & $\begin{array}{c}\text { Pressure } \\
\text { Reading, psia }\end{array}$ \\
\hline $8 / 29 / 91$ & $8: 14: 43$ & 21.5656 \\
\hline $8 / 29 / 91$ & $8: 15: 15$ & 21.9231 \\
\hline $8 / 29 / 91$ & $8: 15: 43$ & 22.2191 \\
\hline $8 / 29 / 91$ & $8: 16: 14$ & 22.5562 \\
\hline $\begin{array}{l}8 / 29 / 91 \\
8 / 29 / 91\end{array}$ & $8: 16: 46$ & 22.8813 \\
\hline $\begin{array}{l}8 / 29 / 91 \\
8 / 29 / 91\end{array}$ & $8: 17: 14$ & 23.1500 \\
\hline $\begin{array}{l}8 / 29 / 91 \\
8 / 29 / 91\end{array}$ & $\begin{array}{l}8: 17: 46 \\
8: 18: 14\end{array}$ & $\begin{array}{l}23.4549 \\
23.7081\end{array}$ \\
\hline $8 / 29 / 91$ & $8: 19: 11$ & 24.2181 \\
\hline $8 / 29 / 91$ & $8: 21: 54$ & 25.5401 \\
\hline $8 / 29 / 91$ & $8: 22: 12$ & 25.6631 \\
\hline $8 / 29 / 91$ & $8: 22: 39$ & 25.8466 \\
\hline $\begin{array}{l}8 / 29 / 91 \\
8 / 29 / 91\end{array}$ & $8: 23: 11$ & 26.0565 \\
\hline $\begin{array}{l}8 / 29 / 91 \\
8 / 29 / 91\end{array}$ & $\begin{array}{l}8: 23: 38 \\
8: 34: 10\end{array}$ & $\begin{array}{l}26.2303 \\
26\end{array}$ \\
\hline $\begin{array}{l}8 / 29 / 91 \\
8 / 29 / 91\end{array}$ & $\begin{array}{l}8:<4: 10 \\
8: 24: 37\end{array}$ & $\begin{array}{l}<0.4271 \\
26.5913\end{array}$ \\
\hline $8 / 29 / 91$ & $8: 25: 09$ & 26.7771 \\
\hline $\begin{array}{l}8 / 29 / 91 \\
8 / 29 / 91\end{array}$ & $8: 25: 37$ & $\begin{array}{l}26.9319 \\
27\end{array}$ \\
\hline $8 / 29 / 91$ & $8: 26: 41$ & $\begin{array}{l}7.101 \\
27.2771\end{array}$ \\
\hline $8 / 29 / 91$ & $8: 27: 08$ & 27.4109 \\
\hline $8 / 29 / 91$ & $8: 27: 40$ & 27.5724 \\
\hline $8 / 29 / 91$ & $8: 28: 07$ & 27.7047 \\
\hline $8 / 29 / 91$ & $8: 28: 39$ & 27.8540 \\
\hline $8 / 29 / 91$ & $8: 29: 11$ & 27.9998 \\
\hline $\begin{array}{l}8 / 29 / 91 \\
8 / 29 / 91\end{array}$ & $8: 29: 38$ & 28.1190 \\
\hline $\begin{array}{l}8 / 29 / 91 \\
8 / 29 / 91\end{array}$ & $8: 30: 10$ & 28.2545 \\
\hline $\begin{array}{l}8 / 29 / 91 \\
8 / 29 / 91\end{array}$ & $\begin{array}{l}8: 30: 38 \\
8: 31: 10\end{array}$ & $\begin{array}{r}28.3677 \\
28.4964\end{array}$ \\
\hline $8 / 29 / 91$ & $8: 31: 37$ & 28.6019 \\
\hline $8 / 29 / 91$ & $8: 32: 09$ & 28.7226 \\
\hline $8 / 29 / 91$ & $8: 32: 41$ & 28.8392 \\
\hline $\begin{array}{l}8 / 29 / 9 \\
8 / 29 / 91\end{array}$ & $8: 33: 08$ & 28.9360 \\
\hline $\begin{array}{l}8 / 29 / 91 \\
8 / 29 / 91\end{array}$ & $\begin{array}{l}8: 33: 40 \\
8: 34: 07\end{array}$ & $\begin{array}{l}29.044 \\
29.1347\end{array}$ \\
\hline $8 / 29 / 91$ & $8: 34: 39$ & 29.2376 \\
\hline $8 / 29 / 91$ & $8: 35: 25$ & 29.3772 \\
\hline $8 / 29 / 91$ & $8: 36: 11$ & 29.5141 \\
\hline $8 / 29 / 91$ & $8: 37: 07$ & 29.6691 \\
\hline $8 / 29 / 91$ & $8: 38: 07$ & 29.8274 \\
\hline $8 / 29 / 91$ & $8: 39: 08$ & 29.9745 \\
\hline & $8: 40: 09$ & 30.1130 \\
\hline $8 / 29 / 91$ & $8: 41: 10$ & 30.2432 \\
\hline $8 / 29 / 91$ & $8: 42: 10$ & 30.3635 \\
\hline $8 / 29$ & $8: 43: 11$ & 30.4765 \\
\hline $8 / 29 / 91$ & $8: 44: 07$ & 30.5739 \\
\hline
\end{tabular}

\section{B. 4}


TABLE B.1. (contd)

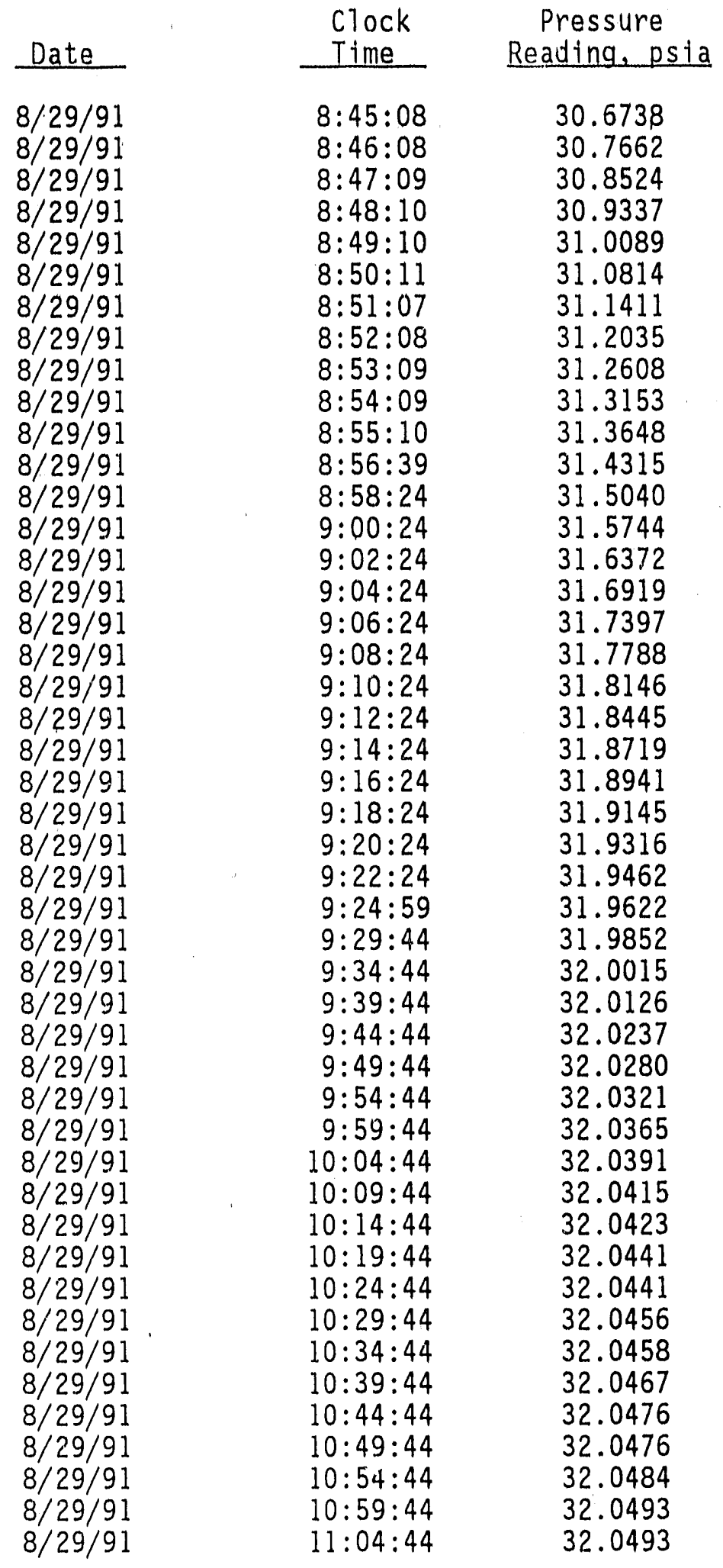

B. 5 
TABLE B.1. (contd)

\begin{tabular}{|c|c|c|}
\hline Date & $\begin{array}{l}\text { Clock } \\
\text { Time }\end{array}$ & $\begin{array}{c}\text { Pressure } \\
\text { Reading, psi }\end{array}$ \\
\hline $8 / 29 / 91$ & $11: 09: 44$ & 32.0484 \\
\hline $8 / 29$ & $11: 14: 44$ & 32.0493 \\
\hline $8 / 29 / 91$ & $11: 19: 44$ & 32.0510 \\
\hline $8 / 29 / 91$ & $11: 24: 44$ & 32.0519 \\
\hline $8 / 29 / 91$ & $11: 29: 44$ & 32.0510 \\
\hline $8 / 29 / 91$ & $11: 34: 44$ & 32.0519 \\
\hline $8 / 29 / 91$ & $11: 39: 44$ & 32.0510 \\
\hline $8 / 29 / 91$ & $11: 44: 44$ & 32.0519 \\
\hline $8 / 29 / 91$ & $11: 49: 44$ & 32.0528 \\
\hline $8 / 29 / 91$ & $11: 54: 44$ & 32.0534 \\
\hline $8 / 29 / 91$ & $11: 59: 44$ & 32.0534 \\
\hline $8 / 29 / 91$ & $12: 04: 44$ & 32.0534 \\
\hline $8 / 29 / 91$ & $12: 09: 44$ & 32.0543 \\
\hline $8 / 29 / 91$ & $12: 14: 44$ & $3 ? .0510$ \\
\hline $8 / 29 / 91$ & $12: 19: 44$ & 32.0534 \\
\hline $8 / 29 / 91$ & $12: 24: 44$ & $\begin{array}{l}32.0534 \\
32.0528\end{array}$ \\
\hline $8 / 29 / 91$ & $12: 29: 44$ & 32.0528 \\
\hline $8 / 29 / 91$ & $12: 34: 44$ & 32.0519 \\
\hline $8 / 29 / 91$ & $12: 39: 44$ & $\begin{array}{l}32.0510 \\
32.0528\end{array}$ \\
\hline $8 / 29 / 91$ & $12: 44: 44$ & $\begin{array}{l}32.0528 \\
32.0510\end{array}$ \\
\hline $8 / 29 / 91$ & $12: 49: 44$ & 32.0510 \\
\hline $\begin{array}{l}8 / 29 / 91 \\
8 / 29 / 91\end{array}$ & $12: 54: 44$ & $\begin{array}{l}32.0493 \\
32.0484\end{array}$ \\
\hline $\begin{array}{l}8 / 29 / 91 \\
8 / 29 / 91\end{array}$ & $\begin{array}{l}12: 59: 44 \\
13: 04: 44\end{array}$ & $\begin{array}{l}32.0484 \\
32.0528\end{array}$ \\
\hline $8 / 29 / 91$ & $13: 09: 44$ & 32.0519 \\
\hline $8 / 29 / 91$ & $13: 14: 44$ & 32.0543 \\
\hline & $13: 19: 44$ & 32.0543 \\
\hline $8 / 29 / 91$ & $13: 24: 44$ & 32.0543 \\
\hline $8 / 29 / 91$ & $13: 28: 18$ & 32.0510 \\
\hline $8 / 29 / 91$ & $13: 58: 02$ & 32.0528 \\
\hline $8 / 29 / 91$ & $14: 28: 02$ & 32.0528 \\
\hline $8 / 29 / 91$ & $14: 58: 02$ & 32.0510 \\
\hline $8 / 29 / 91$ & $15: 28: 02$ & 32.0502 \\
\hline $8 / 29 / 91$ & $15: 58: 02$ & 32.0484 \\
\hline $8 / 29 / 91$ & $16: 28: 02$ & 32.0467 \\
\hline $8 / 29 / 91$ & $16: 58: 02$ & 32.0450 \\
\hline $8 / 29 / 91$ & $17: 28: 02$ & 32.0432 \\
\hline $8 / 29 / 91$ & $17: 58: 02$ & 32.0415 \\
\hline $8 / 29 / 91$ & $18: 28: 02$ & 32.0415 \\
\hline $8 / 29 / 91$ & $18: 58: 02$ & 32.0319 \\
\hline $8 / 29 / 91$ & $19: 28: 02$ & 32.0408 \\
\hline $8 / 29 / 91$ & $19: 58: 02$ & 32.0415 \\
\hline $8 / 29 / 91$ & $20: 28: 02$ & 32.0432 \\
\hline $8 / 29 / 91$ & $20: 58: 02$ & 32.0450 \\
\hline $8 / 2$ & $21: 28: 02$ & 32.0450 \\
\hline & $21: 58: 02$ & 32.045 \\
\hline
\end{tabular}

B. 6 
TABLE B.1. (contd)

\begin{tabular}{|c|c|c|}
\hline Date & $\begin{array}{l}\text { Clock } \\
\text { Time } \\
\end{array}$ & $\begin{array}{c}\text { Pressure } \\
\text { Reading, psta }\end{array}$ \\
\hline $8 / 29 / 91$ & $22: 28: 02$ & 32.0458 \\
\hline $29 / 91$ & $22: 58: 02$ & 32.0467 \\
\hline $8 / 29 / 91$ & $23: 28: 02$ & 32.0484 \\
\hline $8 / 29 / 91$ & $23: 58: 02$ & 32.0476 \\
\hline 100 & $0: 28: 02$ & $3 ? .0502$ \\
\hline $8 / 30 / 91$ & $0: 58: 02$ & $3<.0502$ \\
\hline $8 / 30 / 91$ & $1: 28: 02$ & 32.0519 \\
\hline $8 / 30 / 91$ & $1: 58: 02$ & 32.0510 \\
\hline $8 / 30 / 91$ & $2: 28: 02$ & 32.0519 \\
\hline $8 / 30 / 91$ & $2: 58: 02$ & 32.0519 \\
\hline $8 / 30 / 91$ & $3: 28: 02$ & 32.0519 \\
\hline $8 / 30 / 91$ & $3: 58: 02$ & 32.0552 \\
\hline $8 / 30 / 91$ & $4: 28: 02$ & 32.0534 \\
\hline 0101 & $4: 58: 02$ & 32.0569 \\
\hline $8 / 30 / 91$ & $5: 28: 02$ & 32.0595 \\
\hline $8 / 30 / 91$ & $5: 58: 02$ & 32.0604 \\
\hline & $6: 28: 03$ & 32.0621 \\
\hline 8 & $6: 58: 03$ & 32.0630 \\
\hline & $7: 28: 03$ & 32.0638 \\
\hline
\end{tabular}

B. 7 
IABLE B.2. Slug Interference Test Data - Observation Well 699-43-41E

Date

$8 / 28 / 91$

$8 / 28 / 91$

$8 / 28 / 91$

$8 / 28 / 91$

$8 / 28 / 91$

$8 / 28 / 91$

$8 / 28 / 91$

$8 / 28 / 91$

$8 / 28 / 91$

$8 / 28 / 91$

$8 / 28 / 91$

$8 / 28 / 91$

$8 / 28 / 91$

$8 / 28 / 91$

$8 / 28 / 91$

$8 / 28 / 91$

$8 / 28 / 91$

$8 / 28 / 91$

$8 / 28 / 91$

$8 / 28 / 91$

$8 / 28 / 91$

$8 / 28 / 91$

$8 / 28 / 91$

$8 / 28 / 91$

$8 / 28 / 91$

$8 / 28 / 91$

$8 / 28 / 91$

$8 / 28 / 91$

$8 / 28 / 91$

$8 / 28 / 91$

$8 / 28 / 91$

$8 / 28 / 91$

$8 / 28 / 91$

$8 / 28 / 91$

$8 / 28 / 91$

$8 / 28 / 91$

$8 / 28 / 91$

$8 / 28 / 91$

$8 / 28 / 91$

$8 / 28 / 91$

$8 / 28 / 91$

$8 / 28 / 91$

$8 / 28 / 91$

$8 / 28 / 91$

$8 / 28 / 91$
Clock Pressure

Time Reading, psta

$10: 30: 13$

$10: 34: 56$

$10: 39: 56$

$10: 44: 56$

$10: 49: 56$

$10: 54: 56$

$11: 05: 03$

$11: 09: 47$

$11: 14: 47$

$11: 19: 47$

$11: 24: 47$

$11: 29: 47$

$11: 32: 14$

$11: 3 ?: 31$

$11: 32: 59$

$11: 33: 26$

$11: 33: 59$

$11: 34: 26$

$11: 34: 58$

$11: 35: 30$

$11: 35: 58$

$11: 36: 30$

$11: 37: 22$

$11: 38: 04$

$11: 46: 43$

$11: 47: 25$

$11: 48: 26$

$11: 49: 27$

$11: 50: 27$

$11: 51: 28$

$11: 52: 29$

$11: 53: 25$

$11: 54: 26$

$11: 55: 27$

$11: 56: 28$

$11: 57: 29$

$11: 58: 25$

$12: 00: 13$

$12: 04: 58$

$12: 09: 58$

$12: 14: 58$

$12: 19: 58$

$12: 24: 58$

$12: 29: 58$

$12: 34: 58$

17.5474

17.5525

17.5559

17.5533

17.5584

17.5653

17.5678

17.5661

17.5678

17.5712

17.5670

17.5653

17.5721

17.5610

17.5567

17.5619

17.5593

17.5661

17.5627

17.5576

17.5584

17.5576

17.5593

17.5804

17.5746

17.5729

17.5787

17.5778

17.5729

17.5729

17.5695

17.5704

17.5687

17.5704

17.5704

17.5687

17.5695

17.5761

17.5695

17.5746

17.5687

17.5721

17.5729

17.5721
17.5712 Began pressurizing casing 
IABLE B.2. (contd)

Date

$8 / 28 / 91$

$8 / 28 / 91$

$8 / 28 / 91$

$8 / 28 / 91$

$8 / 28 / 91$

$8 / 28 / 91$

$8 / 28 / 91$

$8 / 28 / 91$

$8 / 28 / 91$

$8 / 28 / 91$

$8 / 28 / 91$

$8 / 28 / 91$

$8 / 28 / 91$

$8 / 28 / 91$

$8 / 28 / 91$

$8 / 28 / 91$

$8 / 28 / 91$

$8 / 28 / 91$

$8 / 28 / 91$

$8 / 28 / 91$

$8 / 28 / 91$

$8 / 28 / 91$

$8 / 28 / 91$

$8 / 28 / 91$

$8 / 28 / 91$

$8 / 28 / 91$

$8 / 28 / 91$

$8 / 28 / 91$

$8 / 28 / 91$

$8 / 28 / 91$

$8 / 28 / 91$

$8 / 28 / 91$

$8 / 28 / 91$

$8 / 28 / 91$

$8 / 28 / 91$

$8 / 29 / 91$

$8 / 29 / 91$

$8 / 29 / 91$

$8 / 29 / 91$

$8 / 29 / 91$

$8 / 29 / 91$

$8 / 29 / 91$

$8 / 29 / 91$

$8 / 29 / 91$

$8 / 29 / 91$

$8 / 29 / 91$
Pressure

Reading, psia

$12: 39: 58$

$12: 49: 58$

$12: 44: 58$

$12: 54: 58$

$12: 59: 58$

$13: 09: 22$

$13: 19: 06$

$13: 29: 06$

$13: 39: 06$

$13: 49: 06$

$13: 59: 06$

$14: 09: 06$

$14: 19: 06$

$14: 29: 06$

$14: 39: 06$

$14: 49: 06$

$14: 59: 06$

$15: 03: 23$

$15: 33: 06$

$16: 03: 06$

$16: 33: 06$

$17: 03: 06$

$17: 33: 06$

18:03:06

$18: 33: 06$

$19: 03: 06$

$19: 33: 06$

20:03:06

$20: 33: 06$

$21: 03: 06$

$21: 33: 06$

22:03:06

$22: 33: 06$

$23: 03: 06$

$23: 33: 06$

$0: 03: 06$

$0: 33: 06$

$1: 03: 06$

$1: 33: 06$

2:03:06

$2: 33: 06$

3:03:06

$3: 33: 06$

4:03:06

$7: 03: 06$

$7: 33: 06$
17.5721

17.5804

17.5755

17.5729

17.5729

17.5725

17.5738

17.5746

17.5804

17.5755

17.5755

17.5770

17.5795

17.5821

17.5846

17.5838

17.5846

17.5821

17.5778

17.5880

17.5940

17.5923

17.5906

17.5931

17.5974

17.6000

17.6034

17.6025

17.6025

17.6110

17.6127

17.6195

17.6280

17.6127

17.6153

17.6204

17.6170

17.6178

17.6195

17.6238

17.6246

17.6280

17.6287

17.6280

17.6312
17.6212 
IABLE B,2. (contd)

Date

$8 / 29 / 91$

$8 / 29 / 91$

$8 / 29 / 91$

$8 / 29 / 91$

$8 / 29 / 91$

$8 / 29 / 91$

$8 / 29 / 91$

$8 / 29 / 91$

$8 / 29 / 91$

$8 / 29 / 91$

$8 / 29 / 91$

$8 / 29 / 91$

$8 / 29 / 91$

$8 / 29 / 91$

$8 / 29 / 91$

$8 / 29 / 91$

$8 / 29 / 91$

$8 / 29 / 91$

$8 / 29 / 91$

$8 / 29 / 91$

$8 / 29 / 91$

$8 / 29 / 91$

$8 / 29 / 91$

$8 / 29 / 91$

$8 / 29 / 91$

$8 / 29 / 91$

$8 / 29 / 91$

$8 / 29 / 91$

$8 / 29 / 91$

$8 / 29 / 91$

$8 / 29 / 91$

$8 / 29 / 91$

$8 / 29 / 91$

$8 / 29 / 91$

$8 / 29 / 91$

$8 / 29 / 91$

$8 / 29 / 91$

$8 / 29 / 91$

$8 / 29 / 91$

$8 / 29 / 91$

$8 / 29 / 91$

$8 / 29 / 91$

$8 / 29 / 91$

$8 / 29 / 91$

$8 / 29 / 91$

$8 / 29 / 91$ clock Time

$7: 44: 00$

$7: 48: 44$

$7: 53: 44$

$7: 58: 44$

$8: 03: 44$

8:06:05

$8: 06: 23$

$8: 06: 50$

$8: 07: 18$

$8: 07: 50$

8:08:18

8:08:50

8:11:06

$8: 11: 24$

$8: 11: 52$

8:12::19

8:12:51

$8: 13: 23$

8:13:50

$8: 14: 23$

8:14:50

8:15:22

8:15:49

8:16:21

$8: 16: 53$

$8: 17: 21$

$8: 17: 53$

$8: 19: 18$

8:?2:01

$8:\llcorner 2: 19$

$8: 22: 46$

$8: 23: 18$

$8: 23: 45$

$8: 24: 17$

$8: 24: 44$

$8: 25: 16$

$8: 25: 44$

$8: 26: 16$

$8: 26: 48$

$8: 27: 15$

$8: 27: 47$

$8: 28: 14$

$8: 28: 46$

$8: 29: 18$

$8: 29: 45$

$8: 30: 17$
Pressure Reading, psia

17.6272

17.6272

17.6295

17.6280

17.6280

17.6280

17.6272

17.6280

17.6280

17.6238

17.6238

17.6204

17.6127

17.6127

17.6136

17.6102

17.6110

17.6085

17.6093

17.6051

17.5991

17.5940

17.5931

17.5914

17.5880

17.5872

17.5829

17.5812

17.5770

17.5704

17.5678

17.5670

17.5653

17.5627

17.5627

17.5627

17.5610

17.5610

17.5576

17.5585

17.5585

17.5576

17.5567

17.5533

17.5533

17.5508 
IABLE B.2. (contd)

Date

$8 / 29 / 91$

$8 / 29 / 91$

$8 / 29 / 91$

$8 / 29 / 91$

$8 / 29 / 91$

$8 / 29 / 91$

$8 / 29 / 91$

$8 / 29 / 91$

$8 / 29 / 91$

$8 / 29 / 91$

$8 / 29 / 91$

$8 / 29 / 91$

$8 / 29 / 91$

$8 / 29 / 91$

$8 / 29 / 91$

$8 / 29 / 91$

$8 / 29 / 91$

$8 / 29 / 91$

$8 / 29 / 91$

$8 / 29 / 91$

$8 / 29 / 91$

$8 / 29 / 91$

$8 / 29 / 91$

$8 / 29 / 91$

$8 / 29 / 91$

$8 / 29 / 91$

$8 / 29 / 91$

$8 / 29 / 91$

$8 / 29 / 91$

$8 / 29 / 91$

$8 / 29 / 91$

$8 / 29 / 91$

$8 / 29 / 91$

$8 / 29 / 91$

$8 / 29 / 91$

$8 / 29 / 91$

$8 / 29 / 91$

$8 / 29 / 91$

$8 / 29 / 91$

$8 / 29 / 91$

$8 / 29 / 91$

$8 / 29 / 91$

$8 / 29 / 91$

$8 / 29 / 91$

$8 / 29 / 91$

$8 / 29 / 91$
Pressure

Reading, psta

$8: 30: 45 \quad 17.5499$

$8: 31: 17 \quad 17.5474$

$8: 31: 44 \quad 17.5465$

$8: 32: 16 \quad 17.5448$

$8: 32: 48 \quad 17.5423$

8:33:15 $\quad 17.5431$

8:33:47 17.5431

$8: 34: 14 \quad 17.5406$

$8: 34: 46 \quad 17.5380$

$8: 35: 32 \quad 17.5389$

$8: 36: 18 \quad 17.5355$

$8: 37: 14 \quad 17.5389$

$8: 38: 14 \quad 17.5389$

$8: 39: 15 \quad 17.5380$

$8: 40: 16 \quad 17.5423$

$8: 41: 17 \quad 17.5414$

$8: 42: 17 \quad 17.5440$

$8: 43: 18 \quad 17.5474$

$8: 44: 14 \quad 17.5448$

$8: 45: 15 \quad 17.5525$

$8: 46: 15 \quad 17.5525$

$8: 47: 16 \quad 17.5533$

8:48:17 $\quad 17.5525$

$8: 49: 17 \quad 17.5525$

$8: 50: 18 \quad 17.5525$

$8: 51: 14 \quad 17.5516$

$8: 52: 1 \quad 17.5525$

$8: 53: 16 \quad 17.5550$

$8: 54: 16 \quad 17.5525$

$8: 55: 17 \quad 17.5525$

$8: 56: 46 \quad 17.5525$

$8: 58: 31 \quad 17.5533$

$9: 00: 31 \quad 17.5567$

9:02:31 $\quad 17.5567$

$9: 04: 31 \quad 17.5619$

9:06:31 $\quad 17.5602$

9:08:31 $\quad 17.5619$

$9: 10: 31 \quad 17.5593$

$9: 12: 31 \quad 17.5610$

$9: 14: 31 \quad 17.5585$

$9: 16: 31 \quad 17.5593$

$9: 18: 31 \quad 17.5619$

$9: 20: 31 \quad 17.5636$

$9: 22: 31 \quad 17.5644$

$9: 25: 06 \quad 17.5670$

$9: 29: 51 \quad 17.5704$ 
IABLE B.2. (contd)

Date

$8 / 29 / 91$

$8 / 29 / 91$

$8 / 29 / 91$

$8 / 29 / 91$

$8 / 29 / 91$

$8 / 29 / 91$

$8 / 29 / 91$

$8 / 29 / 91$

$8 / 29 / 91$

$8 / 29 / 91$

$8 / 29 / 91$

$8 / 29 / 91$

$8 / 29 / 91$

$8 / 29 / 91$

$8 / 29 / 91$

$8 / 29 / 91$

$8 / 29 / 91$

$8 / 29 / 91$

$8 / 29 / 91$

$8 / 29 / 91$

$8 / 29 / 91$

$8 / 29 / 91$

$8 / 29 / 91$

$8 / 29 / 91$

$8 / 29 / 91$

$8 / 29 / 91$

$8 / 29 / 91$

$8 / 29 / 91$

$8 / 29 / 91$

$8 / 29 / 91$

$8 / 29 / 91$

$8 / 29 / 91$

$8 / 29 / 91$

$8 / 29 / 91$

$8 / 29 / 91$

$8 / 29 / 91$

$8 / 29 / 91$

$8 / 29 / 91$

$8 / 29 / 91$

$8 / 29 / 91$

$8 / 29 / 91$

$8 / 29 / 91$

$8 / 29 / 91$

$8 / 29 / 91$

$8 / 29 / 91$

$8 / 29 / 91$ clock Time

$9: 34: 51$

$9: 39: 51$

$9: 44: 51$

$9: 49: 51$

9:54:51

9:59:51

10:04:51

10:09:51

$10: 14: 51$

$10: 19: 51$

$10: 24: 51$

$10: 29: 51$

$10: 34: 51$

$10: 39: 51$

$10: 44: 51$

$10: 49: 51$

$10: 54: 51$

$10: 59: 51$

11:04:51

11:09:51

$11: 14: 51$

$11: 19: 51$

$11: 24: 51$

11:29:51

$11: 34: 5.1$

$11: 39: 51$

$11: 44: 51$

$11: 49: 51$

$11: 54: 51$

$11: 59: 51$

$12: 04: 51$

$12: 09: 51$

$12: 14: 51$

$12: 19: 51$

$12: 24: 51$

$12: 29: 51$

$12: 34: 51$

$12: 39: 51$

$12: 44: 51$

$12: 49: 51$

$12: 54: 51$

12:59:51

13:04:51

13:09:51

$13: 14: 51$

$13: 19: 51$
Pressure

Reading, psta

17.5704

17.5678

17.5704

17.5755

17.5787

17.5812

17.5804

17.5812

17.5855

17.5889

17.5880

17.5846

17.5897

17.5872

17.5838

17.5880

17.5846

17.5829

17.5889

17.5889

17.5889

17.5897

17.5872

17.5872

17.5855

17.5872

17.5880

17.5914

17.5897

17.5897

17.5965

17.5940

17.5948

17.5948

17.5957

17.5965

17.5940

17.5948

17.5923

17.5906

17.5914

17.5923

17.5957

17.5889

17.5889

17.5889 
TABLE B.2. (contd)

\begin{tabular}{|c|c|c|}
\hline Date & $\begin{array}{l}\text { Clock } \\
\text { Time } \\
\end{array}$ & $\begin{array}{c}\text { Pressure } \\
\text { Reading, psia } \\
\end{array}$ \\
\hline $8 / 29 / 91$ & $13: 24: 51$ & 17.5880 \\
\hline $\begin{array}{l}8 / 29 / 91 \\
8 / 29 / 91\end{array}$ & $13: 28: 25$ & 17.5829 \\
\hline $\begin{array}{l}8 / 29 / 91 \\
8 / 29 / 91\end{array}$ & $13: 58: 09$ & 17.5889 \\
\hline $\begin{array}{l}8 / 29 / 91 \\
8 / 29 / 91\end{array}$ & $\begin{array}{l}14: 28: 09 \\
14: 58.09\end{array}$ & $\begin{array}{l}17.5906 \\
17.5965\end{array}$ \\
\hline $8 / 29 / 91$ & $15: 28: 09$ & 17.5974 \\
\hline $8 / 29 / 91$ & $15: 58: 09$ & 17.5948 \\
\hline $8 / 29 / 91$ & $16: 28: 09$ & 17.5974 \\
\hline $8 / 29 / 91$ & $16: 58: 09$ & 17.5974 \\
\hline $8 / 29 / 91$ & $17: 28: 09$ & 17.5974 \\
\hline $\begin{array}{l}8 / 29 / 91 \\
8 / 29 / 91\end{array}$ & $\begin{array}{l}17: 58: 09 \\
18 \cdot 28: 00\end{array}$ & 17.5965 \\
\hline $\begin{array}{l}8 / 29 / 91 \\
8 / 29 / 91\end{array}$ & $\begin{array}{l}18: 28: 09 \\
18: 58: 09\end{array}$ & $\begin{array}{l}17.5931 \\
17.5940\end{array}$ \\
\hline $8 / 29 / 91$ & $19: 28: 09$ & 17.5948 \\
\hline $\begin{array}{l}8 / 29 / 91 \\
8 / 29 / 91\end{array}$ & $19: 58: 09$ & 17.5931 \\
\hline $\begin{array}{l}8 / 29 / 91 \\
8 / 29 / 91\end{array}$ & $\begin{array}{l}20: 28: 09 \\
20: 58: 09\end{array}$ & $\begin{array}{l}17.5923 \\
17.5880\end{array}$ \\
\hline $8 / 29 / 91$ & $21: 28: 09$ & 17.5880 \\
\hline $8 / 29 / 91$ & $21: 58: 09$ & 17.5948 \\
\hline $8 / 29 / 91$ & $22: 28: 09$ & 17.5914 \\
\hline $\begin{array}{l}8 / 29 / 91 \\
8 / 29 / 91\end{array}$ & 22:58:09 & 17.5948 \\
\hline $\begin{array}{l}8 / 29 / 91 \\
8 / 29 / 91\end{array}$ & $\begin{array}{l}23: 28: 09 \\
23: 58: 09\end{array}$ & $\begin{array}{l}17.5948 \\
17.5957\end{array}$ \\
\hline $8 / 30 / 91$ & $0: 28: 09$ & 17.6000 \\
\hline $8 / 30 / 91$ & $0: 58: 09$ & 17.5965 \\
\hline $8 / 30 / 91$ & $1: 28: 09$ & 17.5983 \\
\hline $8 / 30 / 91$ & $1: 58: 09$ & 17.5931 \\
\hline $8 / 30 / 91$ & $\therefore: 28: 09$ & 17.5940 \\
\hline $8 / 30 /$ & $2: 58: 09$ & 17.5983 \\
\hline $8 / 30 / 91$ & $3: 28: 09$ & 17.6017 \\
\hline $8 / 30 / 91$ & $3: 58: 09$ & 17.6000 \\
\hline $\begin{array}{l}8 / 30 / 9 \\
8 / 30 / 9\end{array}$ & $4: 28: 09$ & $\begin{array}{l}17.5948 \\
17.5991\end{array}$ \\
\hline $\begin{array}{l}8 / 30 / 91 \\
8 / 30 / 91\end{array}$ & $\begin{array}{l}4: 58: 09 \\
5: 28: 09\end{array}$ & $\begin{array}{l}17.5991 \\
17.5965\end{array}$ \\
\hline $8 / 30 / 91$ & $5: 58: 09$ & 17.5957 \\
\hline $8 / 30 / 91$ & $6: 28: 09$ & 17.5957 \\
\hline $8 / 30 / 9$ & $6: 58: 09$ & 17.5948 \\
\hline & $7: 28: 09$ & 17.6000 \\
\hline
\end{tabular}


TABLE B.3. Slug Interference Test Data - Observation We11 699-53-41F

\begin{tabular}{|c|c|}
\hline Date & $\begin{array}{l}\text { Clock } \\
\text { Time }\end{array}$ \\
\hline
\end{tabular}

$8 / 26 / 91$

$8: 46$

$9: 18$

$9: 34$

$8 / 26 / 91$

$10: 08$

$10: 27$

$10: 52$

$11: 05$

$11: 13$

$13: 00$

$13: 02$

$13: 03$

13:04

13:05

13:07

13:09

$13: 09.5$

$13: 10$

$13: 10.5$

$13: 23$

$13: 26$

$13: 33$

$13: 36$

$13: 37$

$13: 38$

$13: 39$

$13: 58$

$14: 21$

$14: 58$

$15: 38$

$12: 04$

$12: 10$

$12: 20$

$12: 30$

$12: 58$

$13: 01$

13:08

$13: 16$

$13: 18$

$13: 18.5$

$13: 20$

$13: 21.5$

29.7064

29.7048

29.7048

29.7056

29.7040

29.5749

29.5856

29.5996

29.6867

29.6892

29.6900

29.6925

29.6925

29.6933

29.6875

29.6834

29.6818

29.6801

29.6505

29.6374

29.6464

29.6555

29.6579

29.6604

29.6620

29.6785

29.6810

29.6818

29.6810

29.6218

29.6234

29.6250

29.6283

29.6292

29.6292

29.6296

29.6296

29.6300

29.6308

29.6312

29.6316

29.6329

29.6329

29.6324

29.6324

29.6320

B. 14 
TABLE B.3. (contd)

\begin{tabular}{|c|c|c|}
\hline Date & $\begin{array}{l}\text { Clock } \\
\text { Time } \\
\end{array}$ & $\begin{array}{c}\text { Pressure } \\
\text { Reading, psia }\end{array}$ \\
\hline $8 / 27 / 91$ & $13: 34$ & 29.6316 \\
\hline $8 / 27 / 91$ & $13: 40$ & 29.6312 \\
\hline $\begin{array}{l}3 / 27 / 91 \\
8 / 27 / 91\end{array}$ & $13: 45$ & 29.6312 \\
\hline $\begin{array}{l}8 / 27 / 91 \\
8 / 27 / 91\end{array}$ & $\begin{array}{l}13: 50 \\
14: 00\end{array}$ & $\begin{array}{l}29.6304 \\
29.6308\end{array}$ \\
\hline $8 / 27 / 91$ & $14: 10$ & 29.6296 \\
\hline $8 / 27 / 91$ & $14: 25$ & 29.6296 \\
\hline $8 / 27 / 91$ & $14: 35$ & 29.6292 \\
\hline $\begin{array}{l}8 / 27 / 91 \\
8 / 27 / 91\end{array}$ & $14: 40$ & 29.6279 \\
\hline $\begin{array}{l}8 / 27 / 91 \\
8 / 27 / 91\end{array}$ & $\begin{array}{l}14: 55 \\
15: 15\end{array}$ & $\begin{array}{l}29.6219 \\
29.6271\end{array}$ \\
\hline $8 / 27 / 91$ & $15: 19$ & 29.6263 \\
\hline $8 / 27 / 91$ & $15: 19.5$ & 29.6250 \\
\hline $8 / 27 / 91$ & $15: 20$ & 29.6242 \\
\hline $\begin{array}{l}8 / 27 / 91 \\
8 / 27 / 01\end{array}$ & $15: 20.5$ & 29.6238 \\
\hline $\begin{array}{l}8 / 27 / 91 \\
8 / 27 / 91\end{array}$ & $\begin{array}{l}15: 21 \\
15: 215\end{array}$ & $\begin{array}{l}29.6230 \\
29.6222\end{array}$ \\
\hline $8 / 27 / 91$ & $15: 22$ & 29.6222 \\
\hline $8 / 27 / 91$ & $15: 23$ & 29.6213 \\
\hline $8 / 27 / 91$ & $15: 24$ & 29.6209 \\
\hline $\begin{array}{l}8 / 27 / 91 \\
8 / 27 / 91\end{array}$ & $\begin{array}{l}15: 25 \\
15: 26\end{array}$ & $\begin{array}{l}29.6209 \\
29.6205\end{array}$ \\
\hline $8 / 27 / 91$ & $15: 28$ & 29.6189 \\
\hline $8 / 27 / 91$ & $15: 29$ & 29.6193 \\
\hline $8 / 27 / 91$ & $\begin{array}{l}15: 30 \\
15: 32\end{array}$ & 29.6197 \\
\hline $\begin{array}{l}8 / 27 / 91 \\
8 / 28 / 91\end{array}$ & $\begin{array}{l}15: 32 \\
9: 30: 00\end{array}$ & $\begin{array}{l}29.6205 \\
29.6386\end{array}$ \\
\hline $8 / 28 / 91$ & $10: 34: 00$ & 29.6415 \\
\hline $8 / 28 / 91$ & $10: 44: 00$ & 29.6403 \\
\hline $\begin{array}{l}8 / 28 / 91 \\
8 / 28 / 91\end{array}$ & $\begin{array}{l}10: 48: 00 \\
10: 50: 00\end{array}$ & $\begin{array}{l}29.6403 \\
29.6394\end{array}$ \\
\hline $8 / 28 / 91$ & $11: 08: 00$ & 29.6398 \\
\hline $8 / 28 / 91$ & $11: 12: 00$ & 29.6394 \\
\hline $8 / 28 / 91$ & $11: 18: 00$ & 29.6398 \\
\hline $\begin{array}{l}8 / 28 / 91 \\
8 / 28 / 91\end{array}$ & $11: 25: 00$ & 29.6398 \\
\hline $\begin{array}{l}8 / 28 / 91 \\
8 / 28 / 91\end{array}$ & $\begin{array}{l}11: 32: 00 \\
11: 33: 00\end{array}$ & $\begin{array}{l}29.6403 \\
29.6403\end{array}$ \\
\hline $8 / 28 / 91$ & $\begin{array}{l}11: 33: 00 \\
11: 34: 00\end{array}$ & $\begin{array}{l}29.6403 \\
29.6411\end{array}$ \\
\hline $8 / 28 / 91$ & $11: 35: 00$ & 29.6427 \\
\hline $8 / 28$ & $11: 36: 00$ & 29.6448 \\
\hline $8 / 28 / 91$ & $11: 37: 00$ & 29.6472 \\
\hline $8 / 28 / 91$ & $11: 38: 00$ & 29.6514 \\
\hline $8 / 28 /$ & $11: 40: 00$ & 29.6588 \\
\hline $8 / 28 / 91$ & $11: 42: 00$ & 29.6625 \\
\hline $8 / 28 / 91$ & $11: 49: 00$ & 29.6678 \\
\hline & & \\
\hline
\end{tabular}


TABLE B.3. (contd)

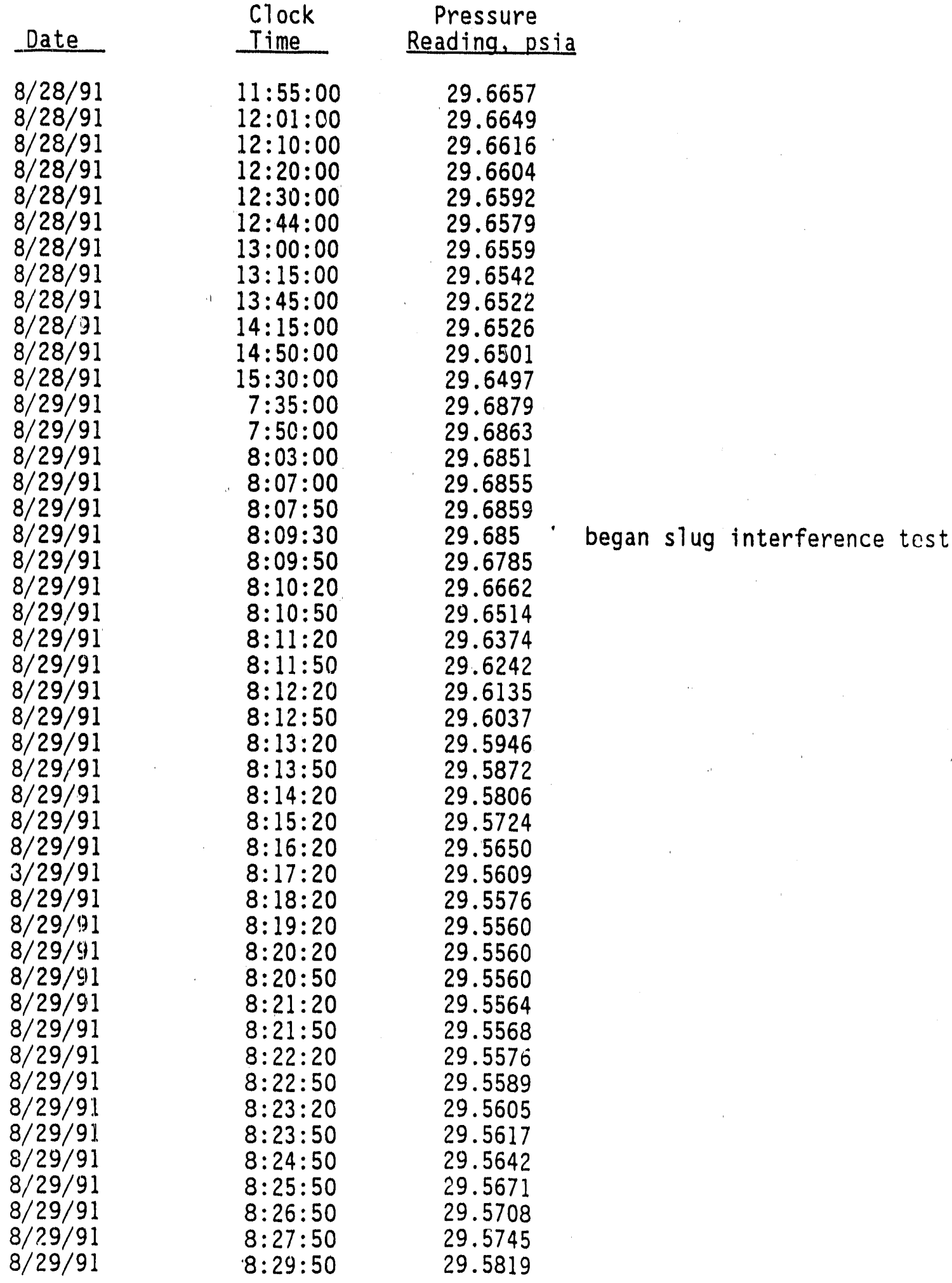


TABLE B.3. (contd)

Clock

Time

$8: 31: 50$

$8: 33: 50$

$8: 35: 50$

$8: 37: 50$

$8: 40: 00$

$8: 45: 00$

$8: 50: 00$

$8: 55: 00$

9:00:00

9:05:00

9:10:00

$9: 15: 00$

$9: 20: 00$

$9: 30: 00$

$9: 40: 00$

$9: 50: 00$

10:00:00

$10: 15: 00$

$10: 30: 00$

$10: 45: 00$

$11: 00: 00$

$11: 15: 00$

$11: 30: 00$

$11: 45: 00$

12:00:00

$12: 15: 00$

$12: 30: 00$

$12: 45: 00$

13:00:00

$13: 30: 00$

14:00:00

$14: 30: 00$

15:00:00

$15: 15: 00$
Pressure

Reading, psia

29.5893

29.5963

29.6037

29.6102

29.6172

29.6287

29.6390

29.6464

29.6530

29.6575

29.6616

29.6645

29.6678

29.6715

29.6731

29.6752

29.6773

29.6781

29.6797

29.6805

29.6814

29.6805

29.6797

29.6797

29.6797

29.6797

29.6789

29.6789

29.6797

29.6797

29.6781

29.6781

29.6773

29.6773 


\section{APPENDIX C}

\section{PREVIOUS SINGLE-WELL SLUG TEST ANALYSIS RESULTS}

C.1. Observation We11 699-43-41E

C.2. Observation We11 699-43-41F 


\section{C.1 PREVIOUS SINGLE-WELL SLUG TEST ANALYSIS RESULTS - OBSERVATION}

WELL 699-43-41E

A low stress $\left(H_{0}=3.54 \mathrm{ft}\right)$ slug injection test was conducted at wel1 699-43-41E on June 29, 1989, The slug test was initiated by rapidly submerging a slugging rod of known volume $\left(0.326 \mathrm{ft}^{3}\right)$, and recording the associated pressure recovery response to static condition with a downhole pressure transducer and surface data recording system. A detailed des,cription of the test and listing of field test data is provided in Borghese and Goodwin (1989).

The slug injection data were analyzed using the same analytical methods (i.e., Ostrowski and Kloska (1989) and Bouwer and Rice (1976) used in analyzing the single-well test at well 699-43-41G. A brief description of the two analysis methods is provided in Section 5.4.2. Figure $C-1.1$ shows the type-curve analysis of the slug injection test response at we11 699-43-41E using the 0strowski and Kloska (1989) analysis procedure. Pertinent analysis information is provided in the figure. As indicated, a transmissivity of approximately $11 \mathrm{ft}^{2} / \mathrm{d}$ was calculated for the screened interval section using a type-curve match of alpha $=10^{-6}$. Based on a well screen interval length of $10.6 \mathrm{ft}$, an equivalent hydraulic conductivity of $1.0 \mathrm{ft} / \mathrm{d}$ for the test interval is indicated.

As a means of analysis method comparison, the slug injection test results were also interpreted using the Bouwer and Rice (1976) technique. Figure $C-1.2$ shows the results and pertinent information used in this analysis. As indicated, a lower equivalent hydraulic conductivity value of $0.4 \mathrm{ft} / \mathrm{d}$ was obtained, which was based on the following input parameters: $r_{c}=0.1667 \mathrm{ft} ; r_{w}=0.2675 \mathrm{ft}$ (accounting for the effects of the sand-pack envelop as described in Bouwer 1989); In $\left(R_{e} / r_{w}\right)=2.65$ (calculated from Equation 4 and Figure 2 in Bouwer (1989) for $\left.L_{e} / r_{w}=39.626\right) ; y_{0}=3.54 \mathrm{ft}$; $y_{t}=0.707 \mathrm{ft}$ (Figure C-1.2); $L_{e}=10.6 \mathrm{ft} ; L_{w}=20.5 \mathrm{ft} ; H=52 \mathrm{ft}$ (static water level to top of clay layer at $179 \mathrm{ft}$ ); and, $t=20$ min (Figure $\mathrm{C}-1.2$ ).

Because of various deficiencies that were briefly described for both analysis methods in Section 5.4.2, no preferred or "best-estimate" of 
equivalent hydraulic conductivity are assigned for this test. The transmissivity estimates obtained for each analysis method are provided as a range for comparison with slug interference test results. As a consequence, an assigned equivalent hydraulic conductivity range between $0.4 \mathrm{ft} / \mathrm{d}$ and $1.0 \mathrm{ft} / \mathrm{d}$ is provided from analysis of the single-well test at well 699-43-41E. It should be noted that because of the low stress utilized during the slug injection test (i.e., 1/10 that used for the slug interference test), the cited range for equivalent hydraulic conductivity provided for this test is expected to be only representative of hydrogeologic conditions a short distance from the screened interval.

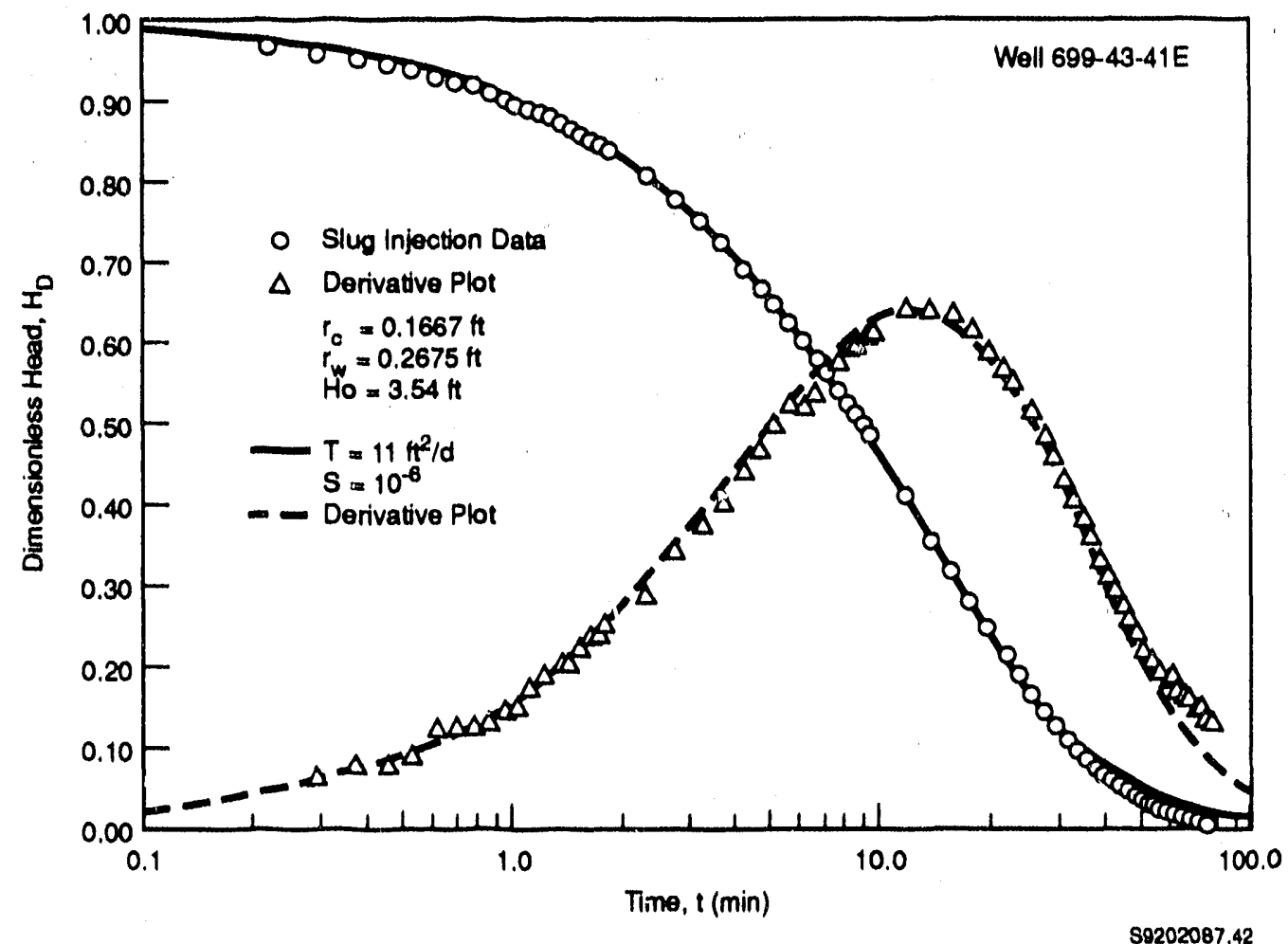

EIGURE C-1.1. Slug Test Analysis for Stress Well 699-43-41E Using the Ostrowski and Kloska (1989) Analysis Method 


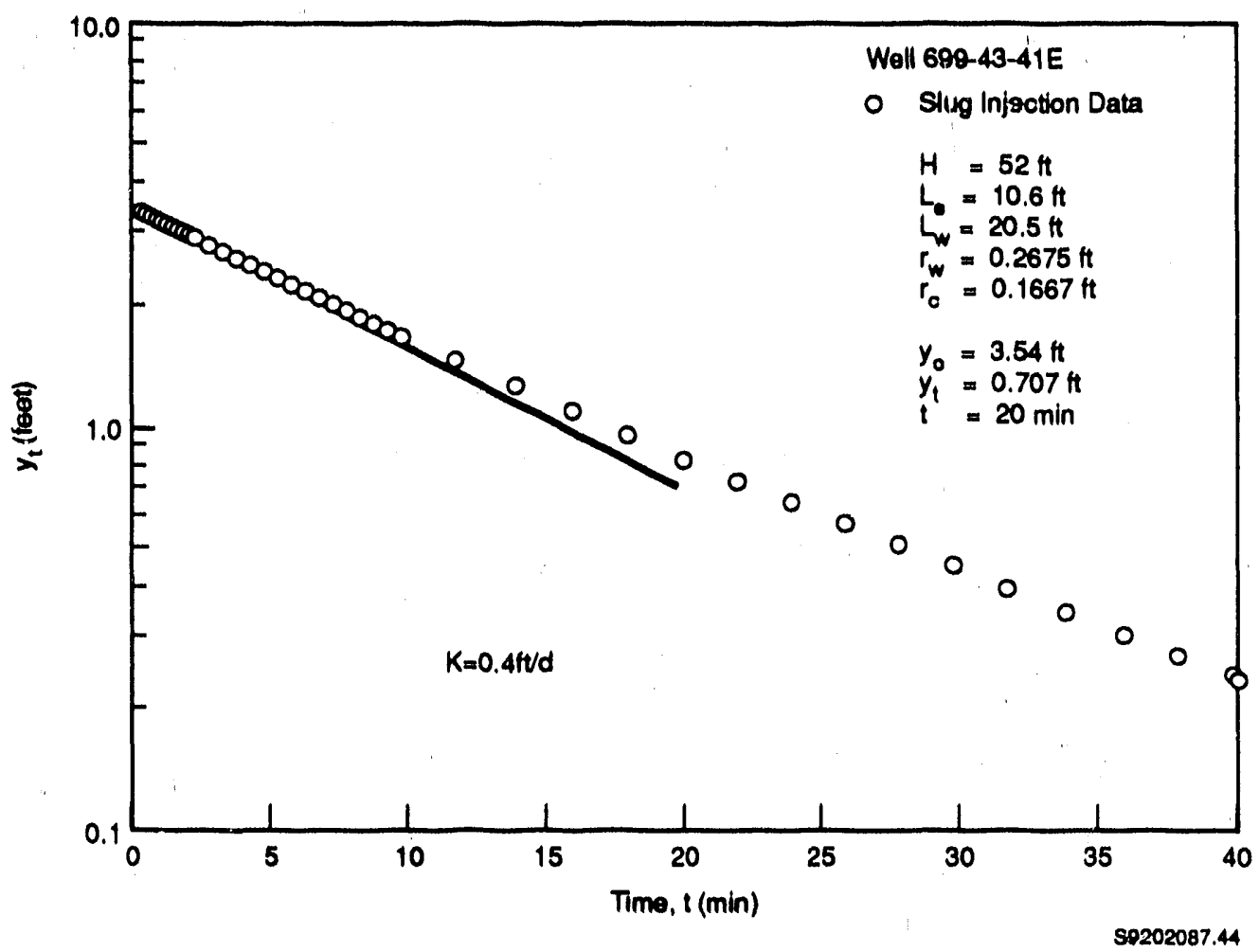

FIGURE C-1.2. Slug Test Analys is for Stress Well 699-43-41E Using the Bouwer and Rice (1976) Analysis Method

\section{C.2 PREVIOUS SINGLE-WELL SLUG TEST ANALYSIS RESULTS - OBSERVATION WELL 699-43-41F}

A low stress $\left(H_{0}=3.69 \mathrm{ft}\right)$ slug injection test was conducted at well 699-43-41F on May 30, 1989. The slug test was initiated by rapidly submerging a slugging rod of known volume $\left(0.32 .6 \mathrm{ft}^{3}\right)$, and recording the associated pressure recovery response to static condition with a downhole pressure transducer and surface data recording system. A detailed description of the test and listing of field test data is provided in Borghese and Goodwin (1989).

The slug injection data were analyzed using the same analytical mechods (i.e., Ostrowski and Kloska (1989) and Bouwer and Rice (1976) used in analyzing the single-well test at well 699-43-41G. A brief description of the two analysis methods is provided in Section 5.4.2. Figure $C-2.1$ shows the type-curve analysis of the slug injection test response at well 699-43-41F using the Ostrowski and Kloska (1989) analysis procedure. Pertinent analysis 
information is provided in the figure. As indicated, a transmissivity of approximately $30 \mathrm{ft}^{2} / \mathrm{d}$ was calculated for the screened interval section using a type-curve match of alpha $=10^{-6}$. Based on a well screen interval length of $10.6 \mathrm{ft}$, an equivalent hydraulic conductivity of $2.8 \mathrm{ft} / \mathrm{d}$ for the test interval is indicated.

As a means of analysis method comparison, the slug injection test results were also interpreted using the Bouwer and Rice (1976) technique. Figure $\mathrm{C}-2.2$ shows the results and pertinent information used in this analysis. As indicated, a lower equivalent hydraulic conductivity value of $1.4 \mathrm{ft} / \mathrm{d}$ was obtained, which was based on the following input parameters: $r_{c}=0.1667 \mathrm{ft} ; r_{w}=0.2675 \mathrm{ft}$ (accounting for the effects of the sand-pack envelop as described in Bouwer, 1989); In $\left(R_{e} / r_{w}\right)=3.741$ (calculated from Equation 4 and Figure 2 in Bouwer (1989) for $\left.L_{e} / r_{w}=39.626\right) ; y_{0}=3.69 \mathrm{ft}$; $y_{t}=0.479 \mathrm{ft}$ (Figure C-2.2); $L_{e}=10.6 \mathrm{ft} ; L_{w}=52 \mathrm{ft} ; H=52 \mathrm{ft}$ (static water level to top of clay layer at $179 \mathrm{ft}$ ); and, $t=10 \mathrm{~min}$ (Figure $\mathrm{C}-2.2$ ).

Because of various deficiencies that were briefly described for both analysis methods in Section 5.4.2, no preferred or "best-estimate" of equivalent hydraulic conductivity are assigned for this test. The transmissivity estimates obtained for each analysis method are provided as a range for comparison with slug interference test results. As a consequence, an assigned equivalent hydraulic conductivity range between $1.4 \mathrm{ft} / \mathrm{d}$ and $2.8 \mathrm{ft} / \mathrm{d}$ is provided from analysis of the single-well iest at well 699-43-41F. It should be noted that because of the low stress utilized during the slug injection test (i.e., 1/10 that used for the slug interference test), the cited rarge for equivalent hydraulic conductivity provided for this test is expected to be only representative of hydrogeologic conditions a short distance from the screened interval. 


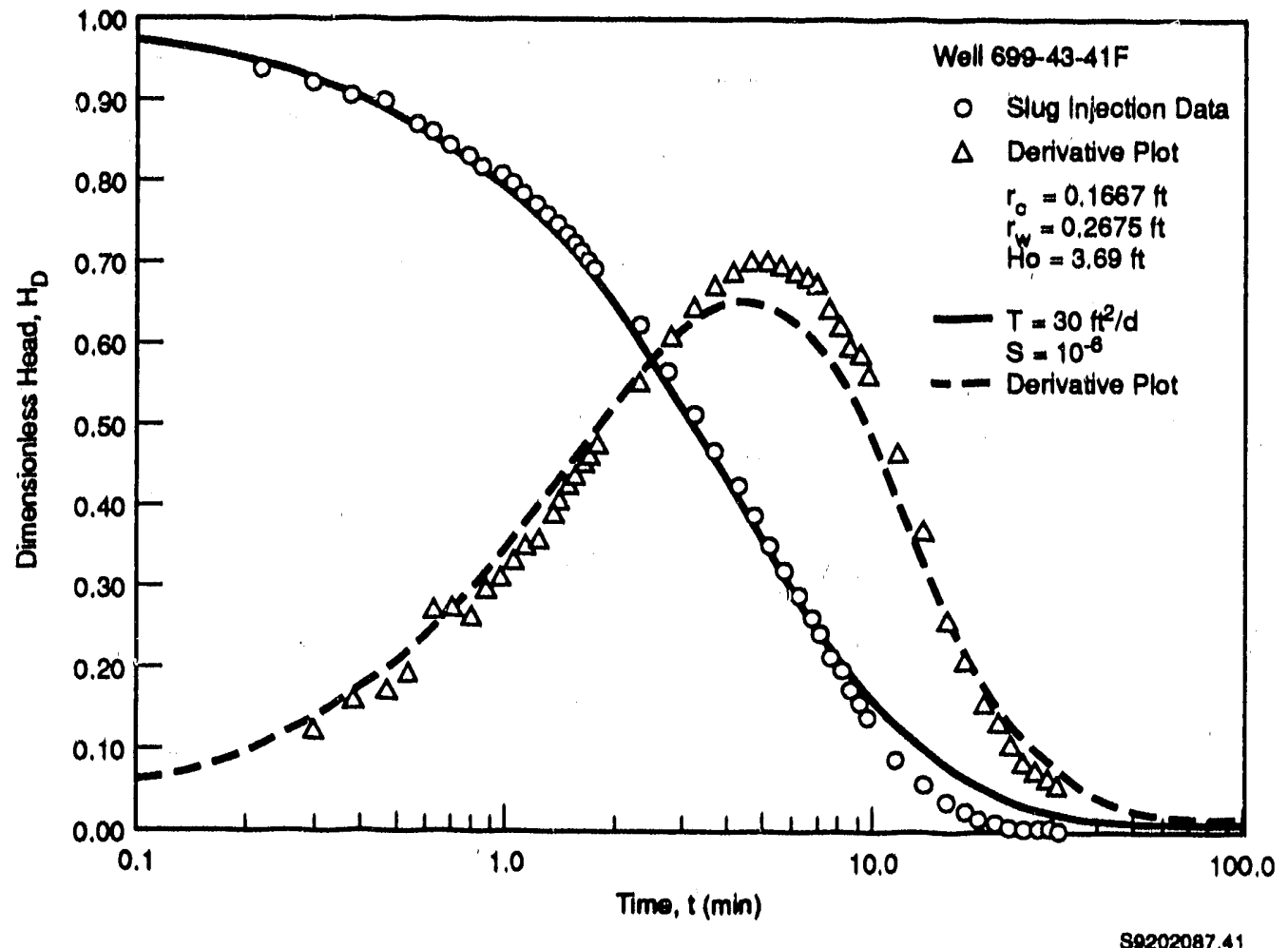

FIGURE C-2.1. Slug Test Analysis for Stress Well 699-43-4IF Using the Ostrowski and Kloska (1989) Analys is Method 


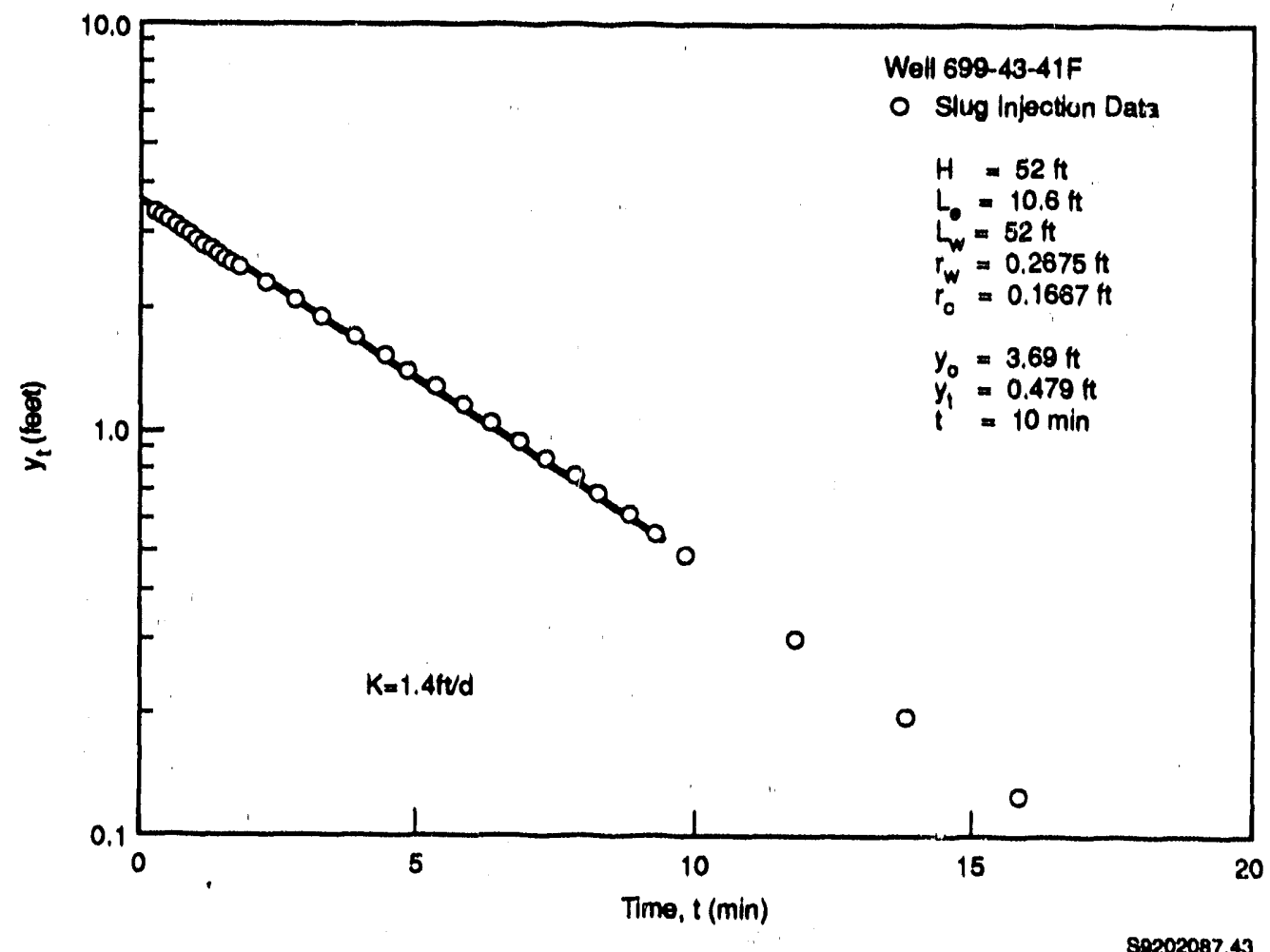

FIGURE C-2.2. Slug Test Analysis for Stress Well 699-43-41F Using the Bouwer and Rice (1976) Analys is Method

\section{REFERENCES}

Bouwer, H: 1989. "The Bouwer and Rice Slug Test -- An Update." Ground Water $27(3): 304-309$.

Bouwer, H., and R. C. Rice. 1976. "A Slug Test for Determining Hydraulic Conductivity of Unconfined Aquifers With Completely or Partially Penetrating We11s." Water Resources Research 12(3):423-428.

Ostrowski, L. P., and M. B. Kloska. 1989. "Use of Pressure Derivatives in Analysis of Slug Test or DST Flow Period Data." Society of Petroleum Engineers, SPE paper 18595. Paper presented at the SPE Production Operations Symposium, OkTahoma City, Oklahoma, March 13-14, 1989. 


\section{DISTRIBUTION}

No. of

No. of

Copies

Copies

OFFSITE

2 DOE/Office of Scientific and Technical Information

\section{ONSITE}

2 DOE Richland Field Office

R. D. Hildebrand

M. W. Tiernan

18 Westinghouse Hanford Company

C. D. Delaney (5)

M. J. Furman

M. J. Hartman

R. L. Jackson (3)

A. J. Knepp

A. G. Law

W. J. McMahon

R. E. Peterson

L. C. Swanson

K. M. Thompson

S. J. Trent

D. K. Tyler

40 Pacific Northwest Laboratory

J. V. Borghese

R. W. Bryce

C. R. Cole

P. G. Doctor

M. D. Freshley

J. S. Fruchter

T. J Gilmore

W. R. Gorst

G. V. Last

$P$. E. Long

S. P. Luttrell

D. R. Newcomer

R. Schalla

F. A. Spane (15)

P. D. Thorne (3)

R. E. Wildung

S. K. Wurstner Publishing Coordination

Technical Report Files (5)

Routing

R. M. Ecker

J. W. Falco

M. J. Graham

R. L. Skaggs

P. C. Hays (1ast) 

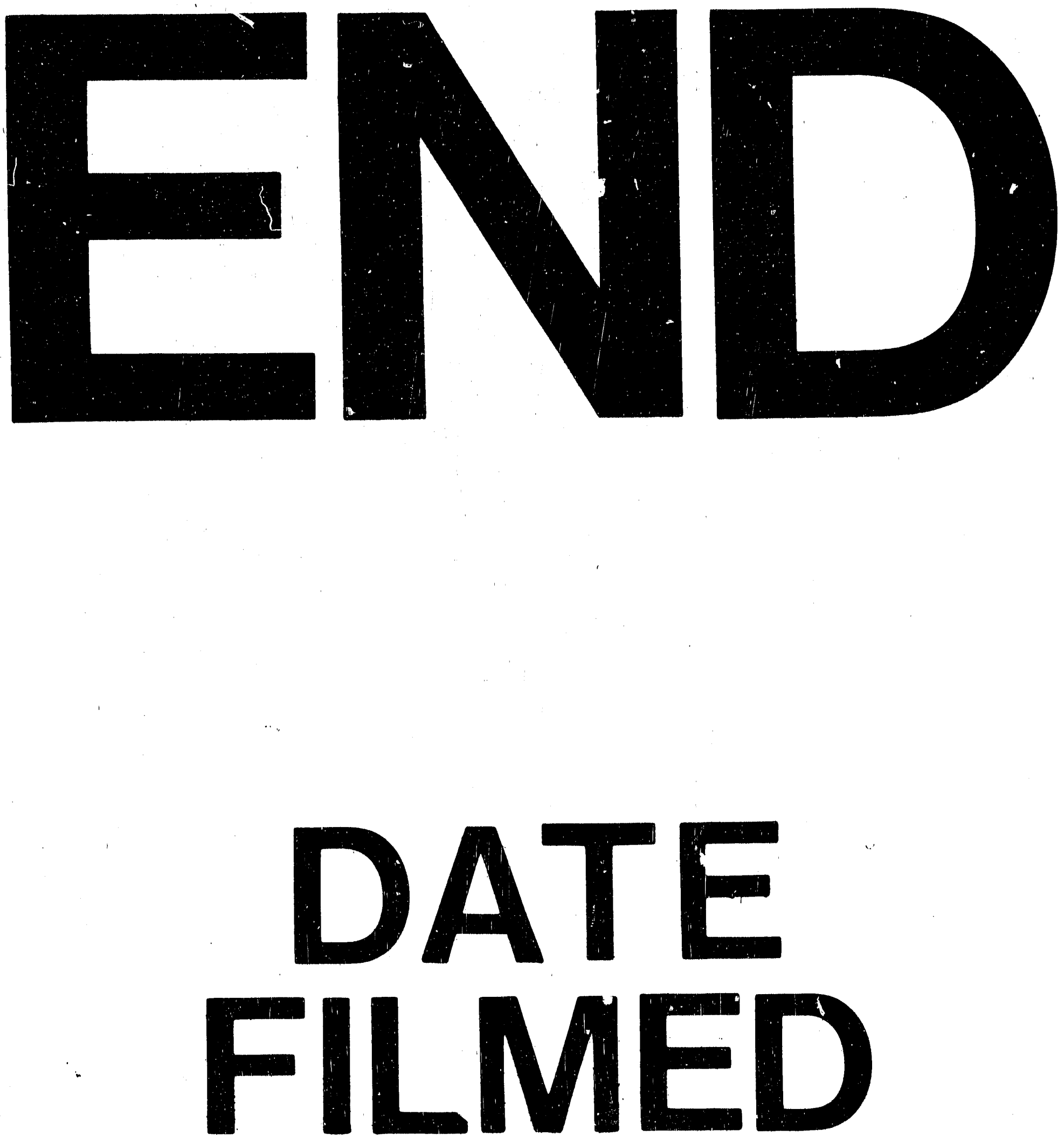

$t$

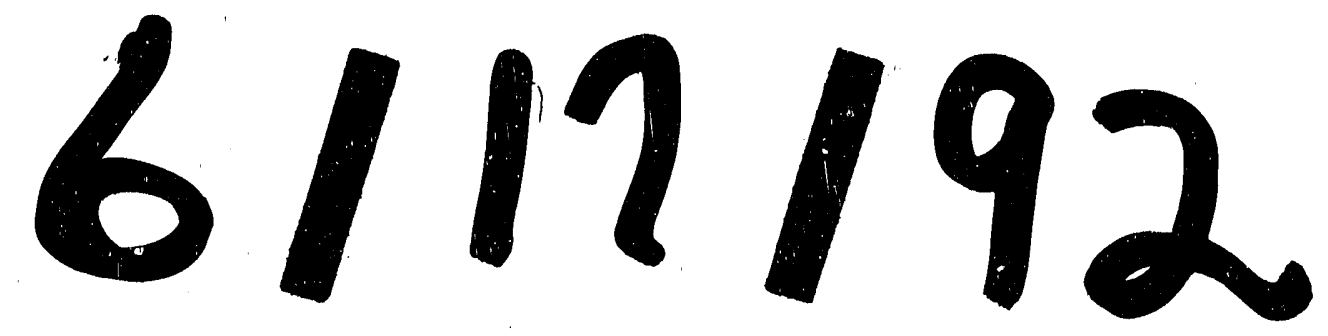


